\title{
FLOOD OF ECOLOGY
}

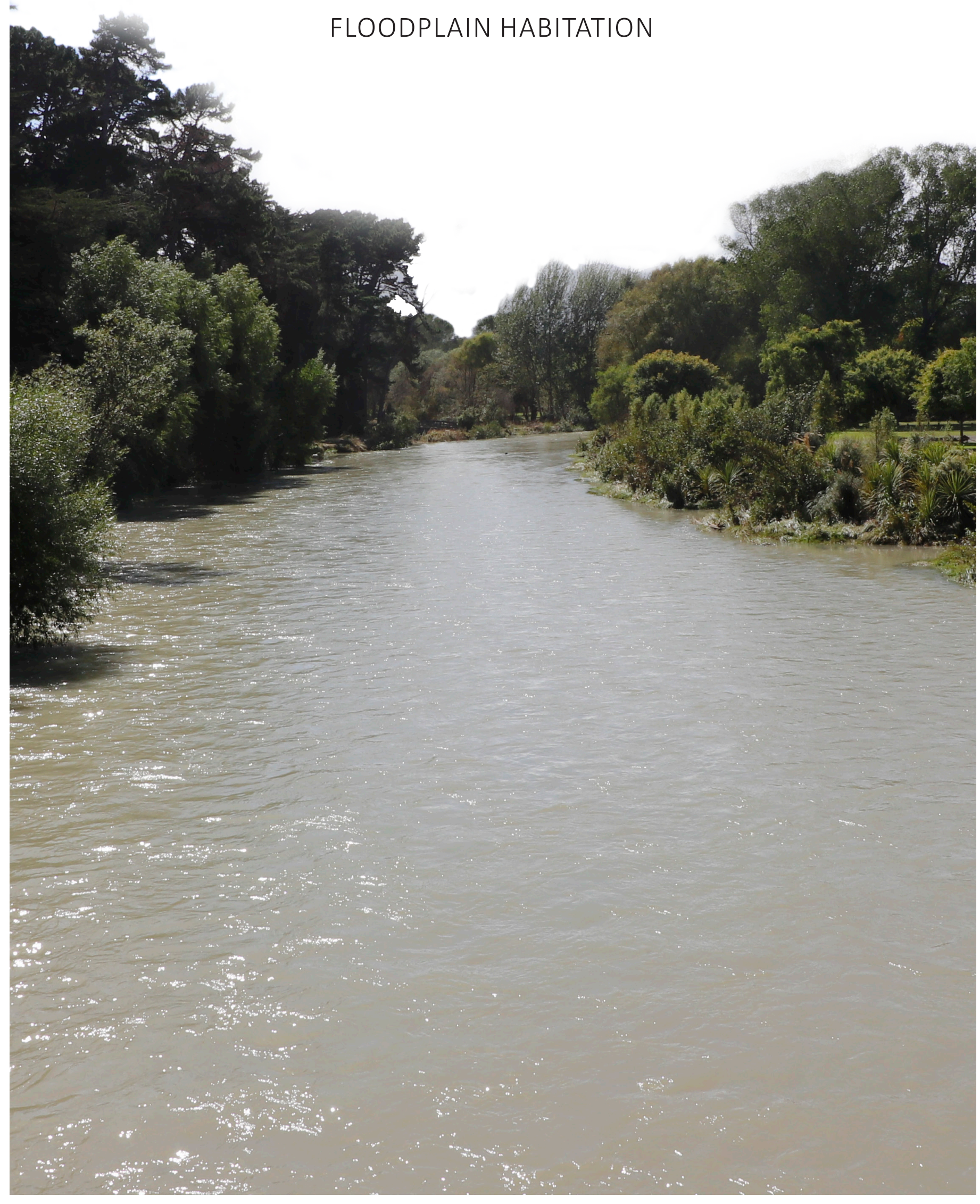




\section{FLOOD OF ECOLOGY}

FLOODPLAIN HABITATION

BY

CHRISTOPHER STANISLAW BRACZEK

A 120-POINT THESIS SUBMITTED TO THE VICTORIA UNIVERSITY OF WELLINGTON IN PARTIAL FULFILLMENT OF THE REQUIREMENTS FOR THE DEGREE OF MASTER OF LANDSCAPE ARCHITECTURE

VICTORIA UNIVERSITY OF WELLINGTON

SCHOOL OF ARCHITECTURE

(2017) 


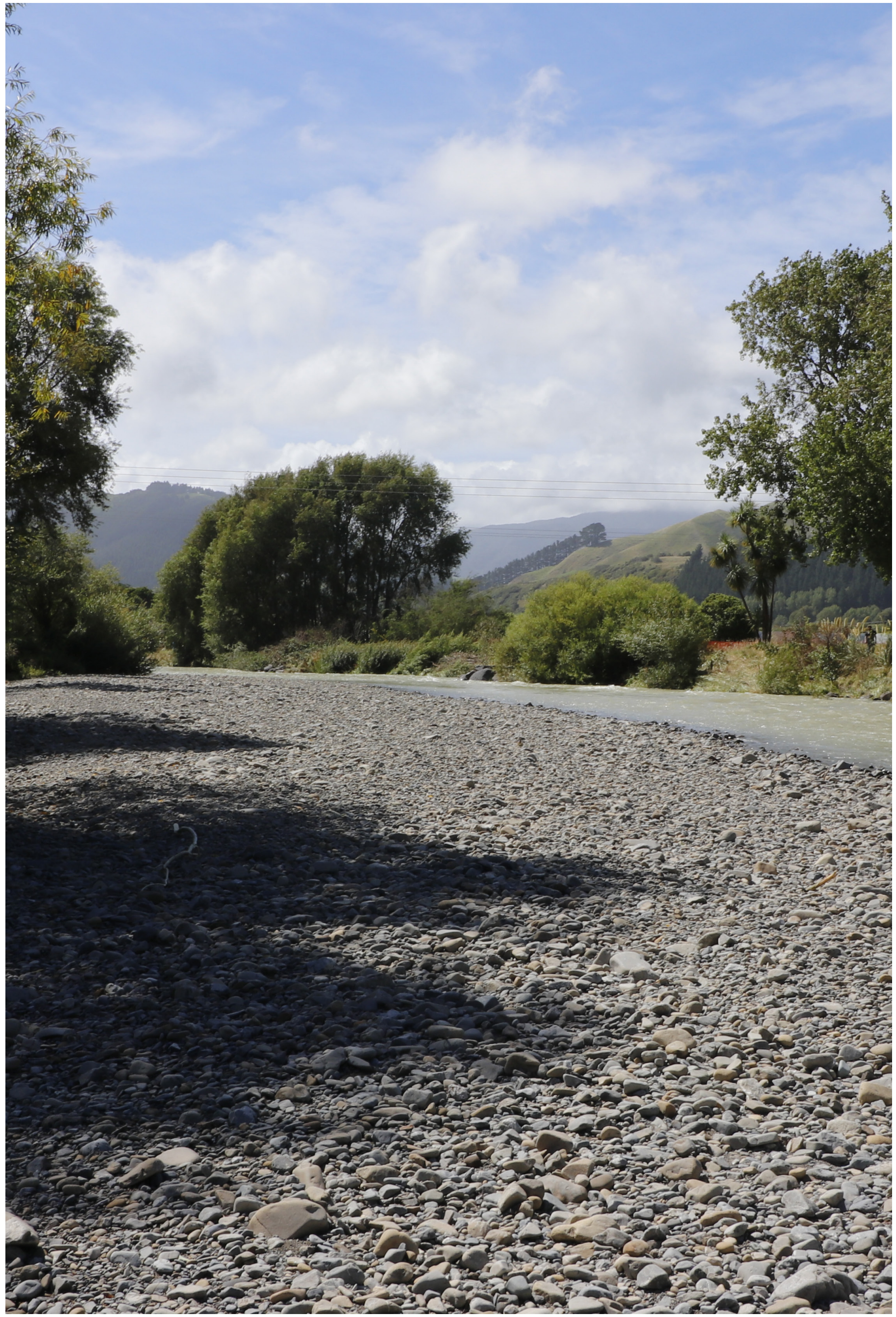




\section{ABSTRACT}

Larger and more devastating flood events are happening more frequently across the planet, but flooding is a natural occurrence for any river system. It is only due to human modification of the river system, through the removal of natural features and attempts at flood control, that creates flood hazards that cause damage to communities and ecosystems.

Kapiti Coast's terrain consisted, pre 19th century, of a mixture of dense coastal forests and extensive wetlands. The landscape has and always will be prone to flooding. With the addition of the expressway to the region, making it easier to travel to and from the capital Wellington, it is expected that the population of Kapiti will grow. But biodiversity may get lost, and flooding may become increasingly more frequent. How might new settlers learn to live with flooding and the constant risk that every time it rains it may cause damage to their homes or businesses? Can there be other benefits to floodplain management, such as biodiversity and recreation?

The aim of this research is to investigate and develop strategies to aid in the settlement of floodplains so that biodiversity is improved, allowing people to live with floods and without the fear that flooding may cause damage. Specifically, the design-led research seeks to generate solutions that improve both flood awareness and flood protection along the Waikanae River. The design seeks to allow the river to express its own flow patterns, and then secondly, how settlement will work within that. It can then be a catalyst for settlement of floodplain areas along the edge of the river.

This thesis will explore how ecology, rehabilitation and natural flood protection can be employed amongst an expanding urban context to create a new way of thinking about our rivers and mitigating the ever pressing issue of flooding. 


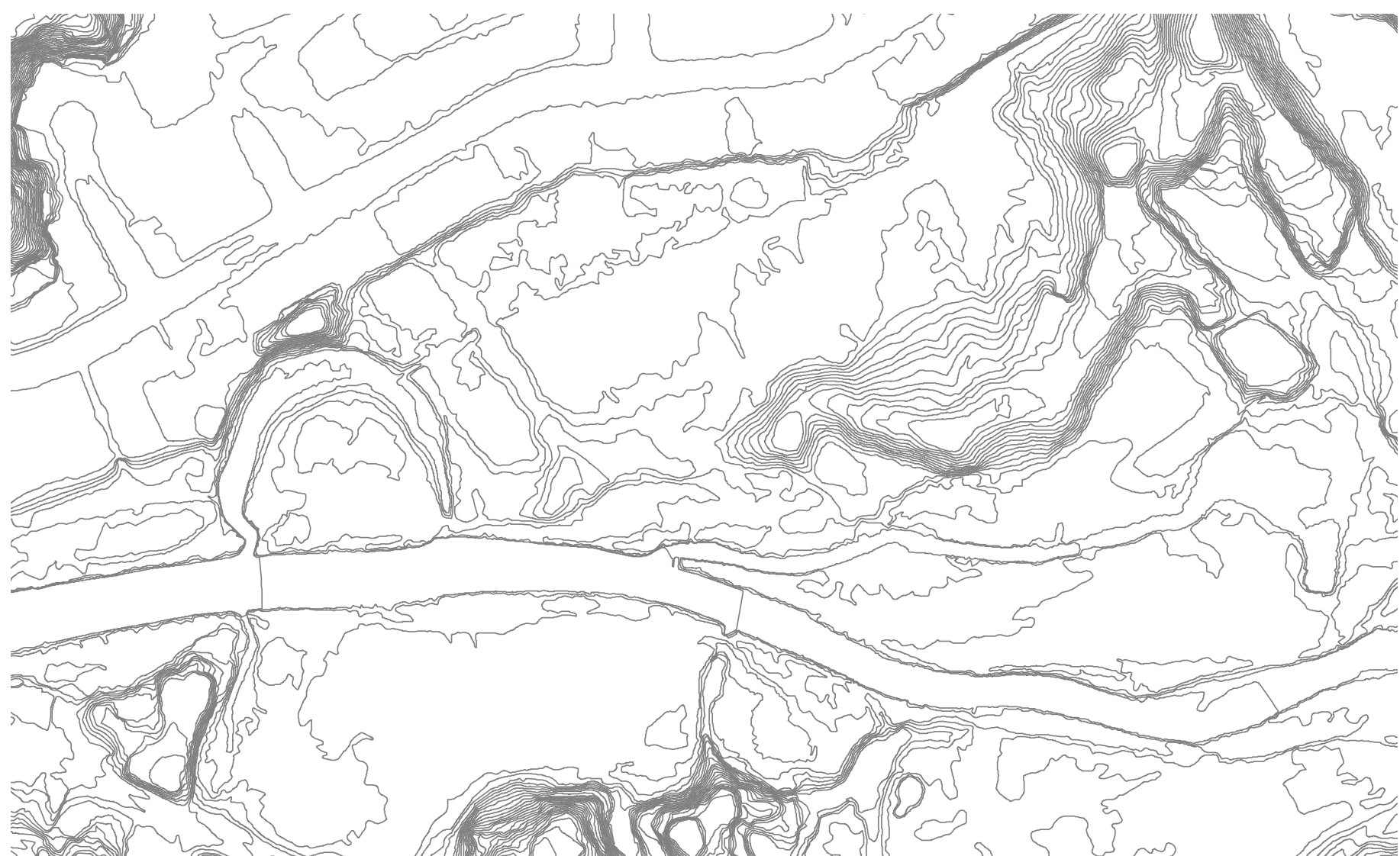

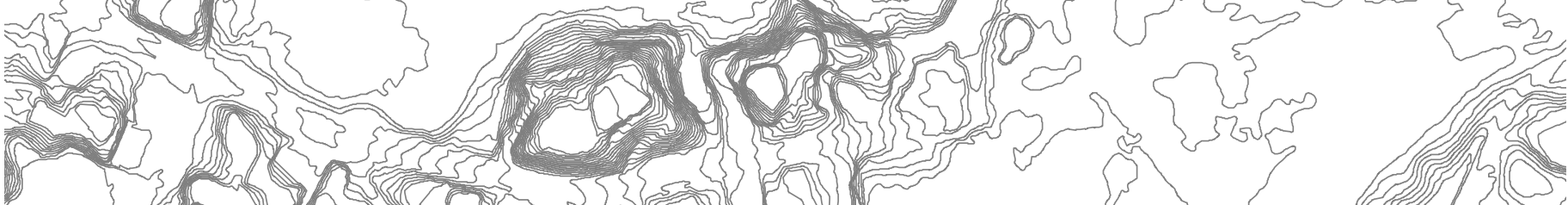



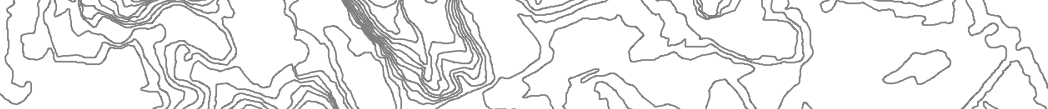

(3) (1) (3) (1) 


\section{CONTENTS}

Abstract

Introduction

Methodology

$\begin{array}{llc}01 & \text { Site } & 5-16 \\ 02 & \text { The Issues } & 17-32 \\ 03 & \text { Initial Design } & 33-50 \\ 04 & \text { Post Design Thinking } & 51-64 \\ 05 & \text { Precedents + Literature } & 65-73 \\ 06 & \text { Concept Design } & 74-82 \\ 07 & \text { Final Design } & 83-104 \\ 08 & \text { Discussion + Conclusion } & 105-111\end{array}$

List of Figures

Bibliography 



\section{INTRODUCTION}

The Kapiti Coast has an abundance of landscape typologies, from the Kapiti Island Nature Reserve, through the Kapiti Marine Reserve, sand dunes and wetlands up to the Tararua Ranges. Tying all of these systems together and transecting the Kapiti Coast are the rivers of the Coast. Running eastwest, they feature most of these typologies in single bands creating a rhythm of ecological corridors along the coastal plain.

The study area for this research is the Waikanae River, from the State Highway One bridge into Waikanae, west downstream to the estuary at the Waikanae River mouth. The river is a highly valued feature of the Kapiti landscape but at times it can also be a highly destructive one.

With the addition of the expressway to the landscape, there will be a significant impact on the Kapiti Coast, making it easier to live on the Coast and commute to Wellington. This will create an influx in the settlement on the coast, but with so much of the current open landscape affected by flooding, there is a need to address the river as a source of biodiversity benefits and a source of flooding problems.

\section{Research Intention}

The aim of this research is to investigate and develop a strategy, to aid in the settlement of floodplains so that biodiversity is improved, without the constant fear that flooding may cause damage to homes and business.

Specifically, the design-led research will seek to generate solutions that improve flood awareness and flood protection along the Waikanae River, allowing the river to express its own flow patterns.

Secondly how this can be a catalyst for settlement to work around that river edge of floodplain areas.

\section{Scope of Design}

The scope of this research relates to the physical context of the site, The Waikanae River. The unique opportunities and constraints that have presented themselves and formed a site-specific response. The strategy created aims to change the way of thinking and viewing flood protection, and how that may embrace biodiversity. It does not aim to alter the structure or style of the settlement, but it does attempt to change views of how settlement along floodplains happens, and may become applicable and applied elsewhere. Limitations to this research are that there is no budget restrictions or communication with regard to property ownership.

\section{Objectives}

This thesis will explore how ecology rehabilitation and natural flood protection can be employed amongst an expanding urban context to create a new way of thinking about flood protection and the condition of our rivers. 

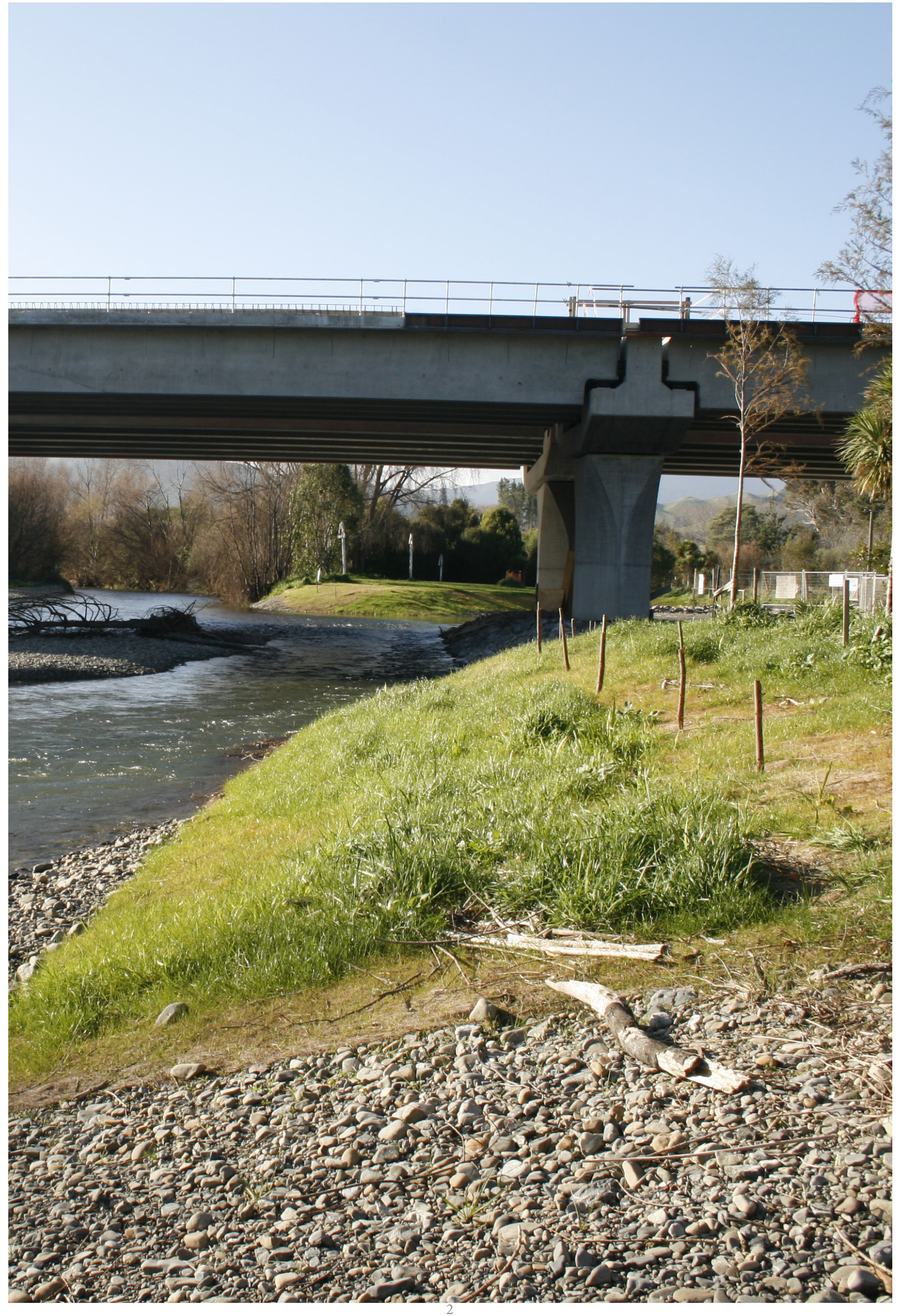


\section{METHOD}

Site

(Kapiti Coast)

Understanding

the site

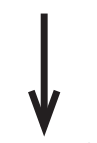

Sea Level Rise

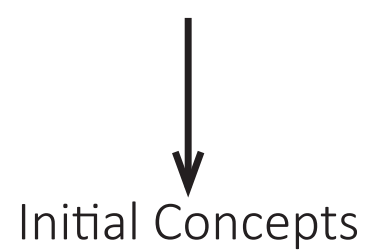

Flooding

Settlement

Ecology

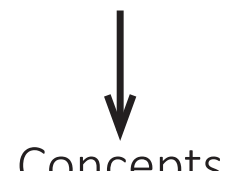

Concepts

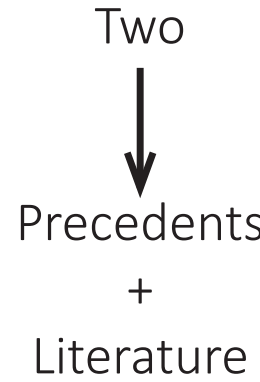

Final Design

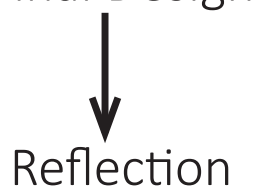

Through trying to understanding how the site works, the process started by exploring a sea level rise scenario to determine the effects of flooding on the site. This provides the research with a greater understanding of the impacts of inundation.

The initial concepts went on to explore settlement in the aftermath of sea level rise where a series of archipelagos is left over as the only landscape. However, the scenario became too narrowly focused on the one scale.

This gave insight into the issues that were happening on site and where the focus area needed to be, gave way to the second round of concepts that looked at a broader scale and had these issues in mind.

This gave insight into the issues being faced on site and Kapiti, giving a new point of focus for further design. Resulting in second round of concepts, looking at a broader scale than the initial concepts.

Ideas discussed about in precedents and literature helped to influence and develop the concepts into a more refined final design. 


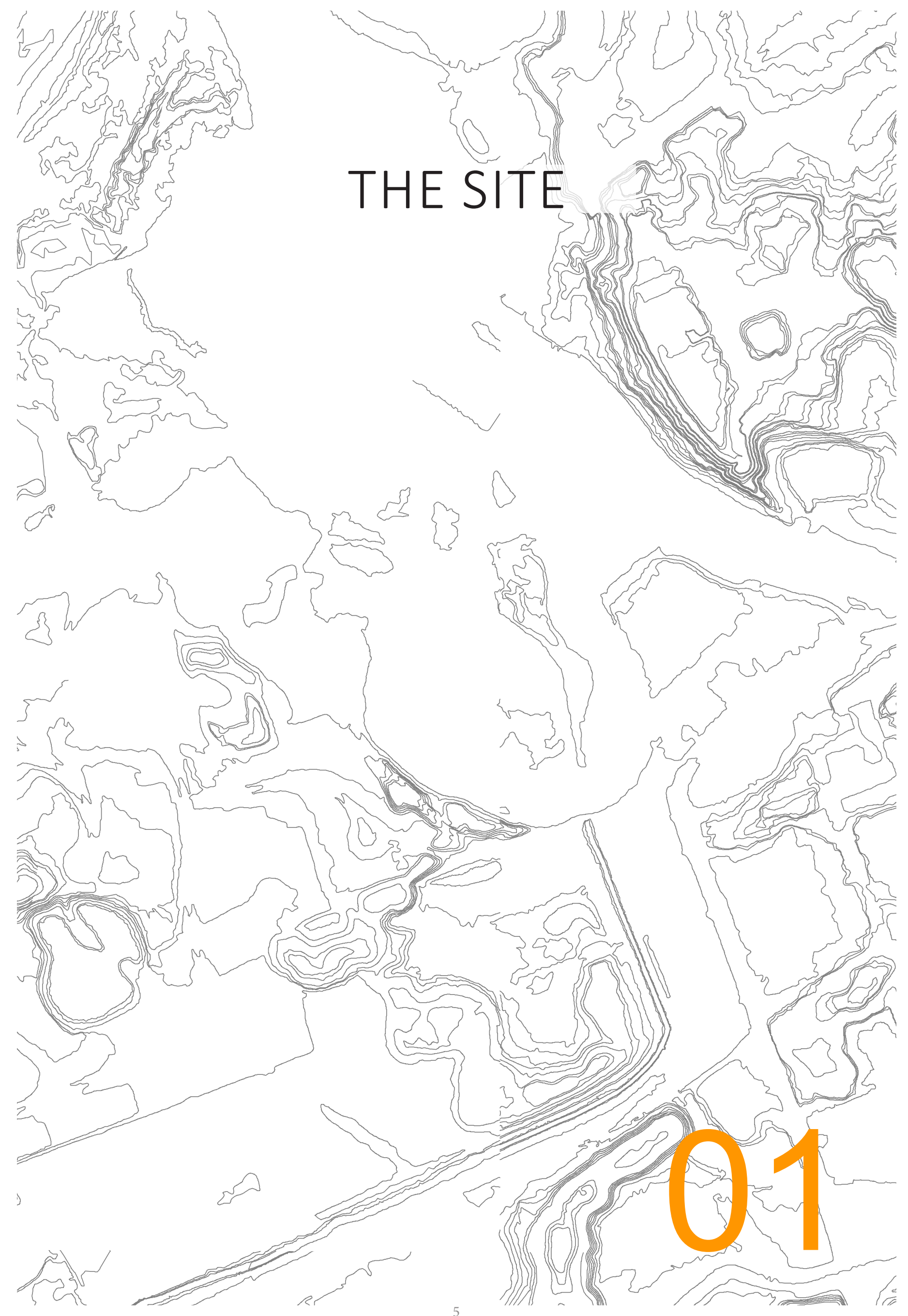






Fig 2.1 // The Kapiti Coast on the south western coast of New Zealand's North Island. A short 40 minute drive from the capital Wellington. 


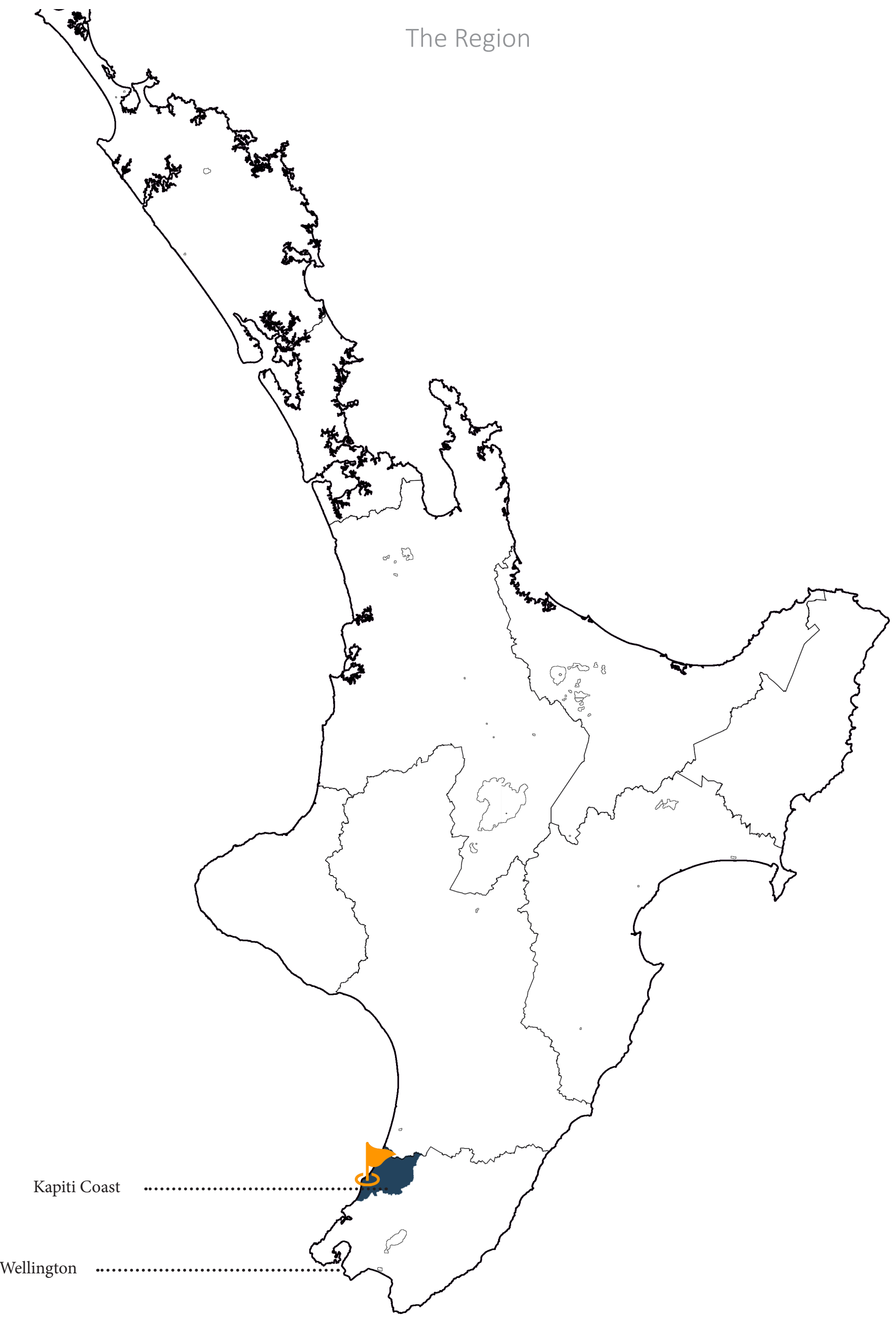

Wellington

Fig 2.2 // The Kapiti Coast sits on the south western coast of New Zealand's North Island. A short 40 minute drive from the capital Wellington. 


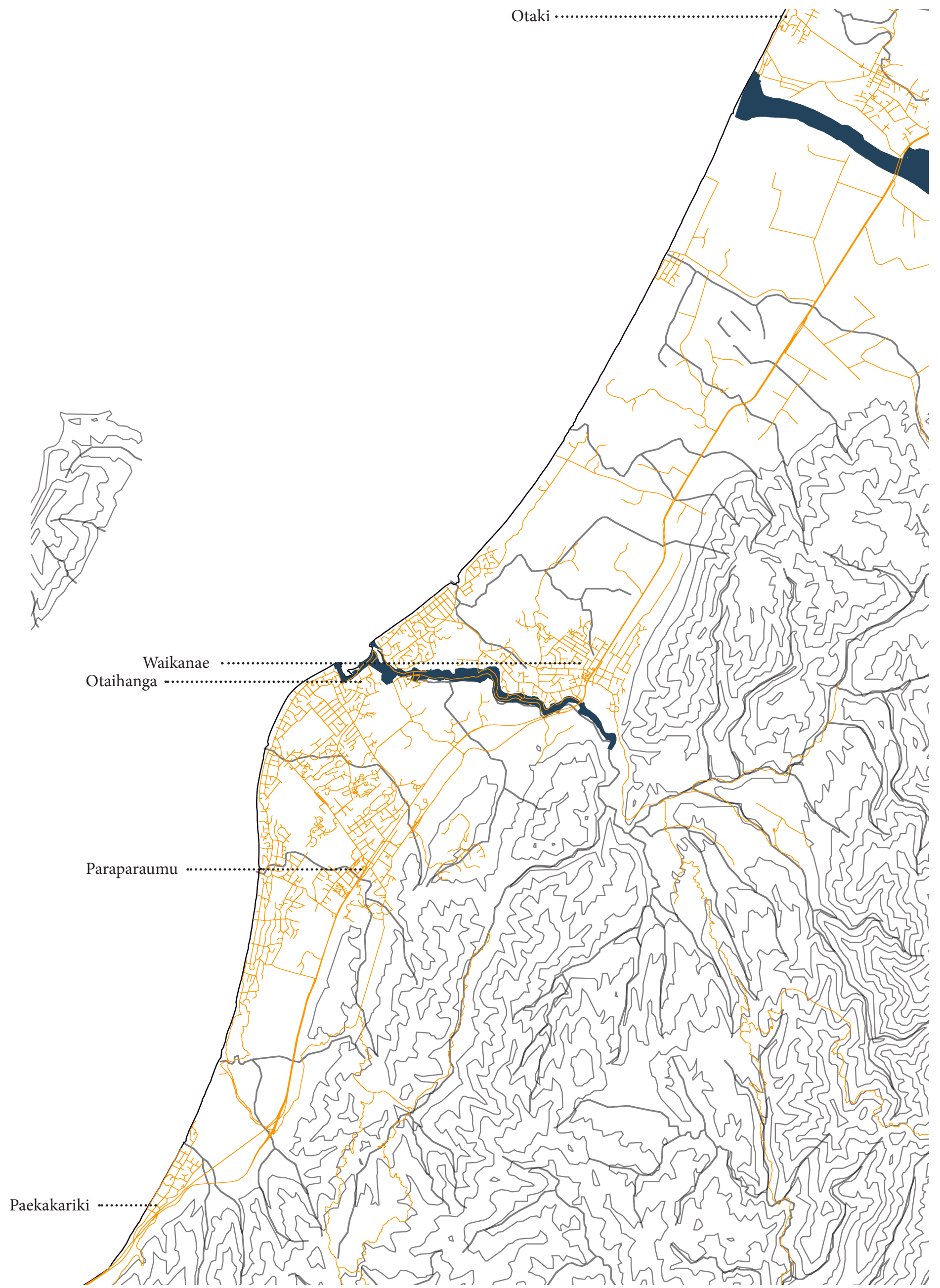

Fig 2.3 // The Kapiti Coast, running from Paekakariki up to Otaki and back into the Tararua Ranges. Town street grid and mountain contours showing relationship of urban and landscape. 


\section{The Region}

The Kapiti Coast is a section of coast along the south-western part of the North Island of New Zealand. Situated $50 \mathrm{~km}$ north of Wellington, it runs from Otaki in the north to Paekakariki in the south and from Kapiti Island to the peaks of the Tararua Ranges in the east including towns like Waikanae, Paraparaumu and Raumati between them. Although it is a part of the Wellington region its location is geographically distant from the rest of the region, but many of its 41800 residents travel to and from Wellington each day for work.

Kapiti's terrain is a thin coastal plain at the foot of the Tararua Ranges which once used to be covered in dune vegetation and swamp forest. Less than $5 \%$ of the indigenous vegetation remains today (Kapiti Coast - Te Hapua Wetland). The best example of what used to be here is the Te Hapua wetland at Te Horo.

Much of the land was drained and cleared in the early 19th century to make way for sheep and dairy farming in the region and developed its way to being a series of seaside resorts in early 1900 (15. - Wellington Places - Te Ara Encyclopedia of New Zealand). After the addition of the Airport in Paraparaumu in the 1940s "15. - Wellington Places - Te Ara Encyclopedia of New Zealand" there was an increase of industry development in places like Waikanae and Otaki which helped it to develop the Kapiti Coast into what it is today.
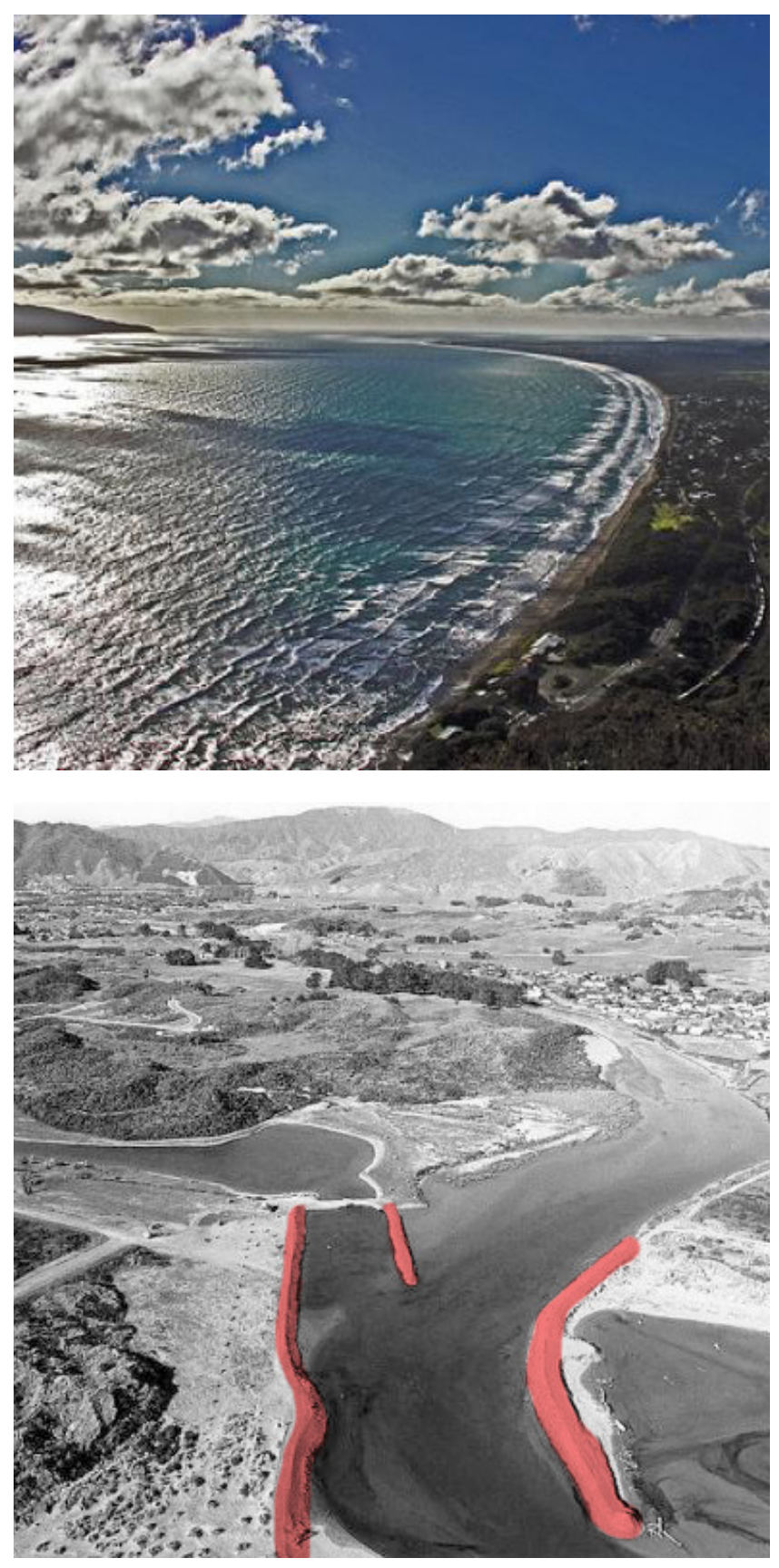


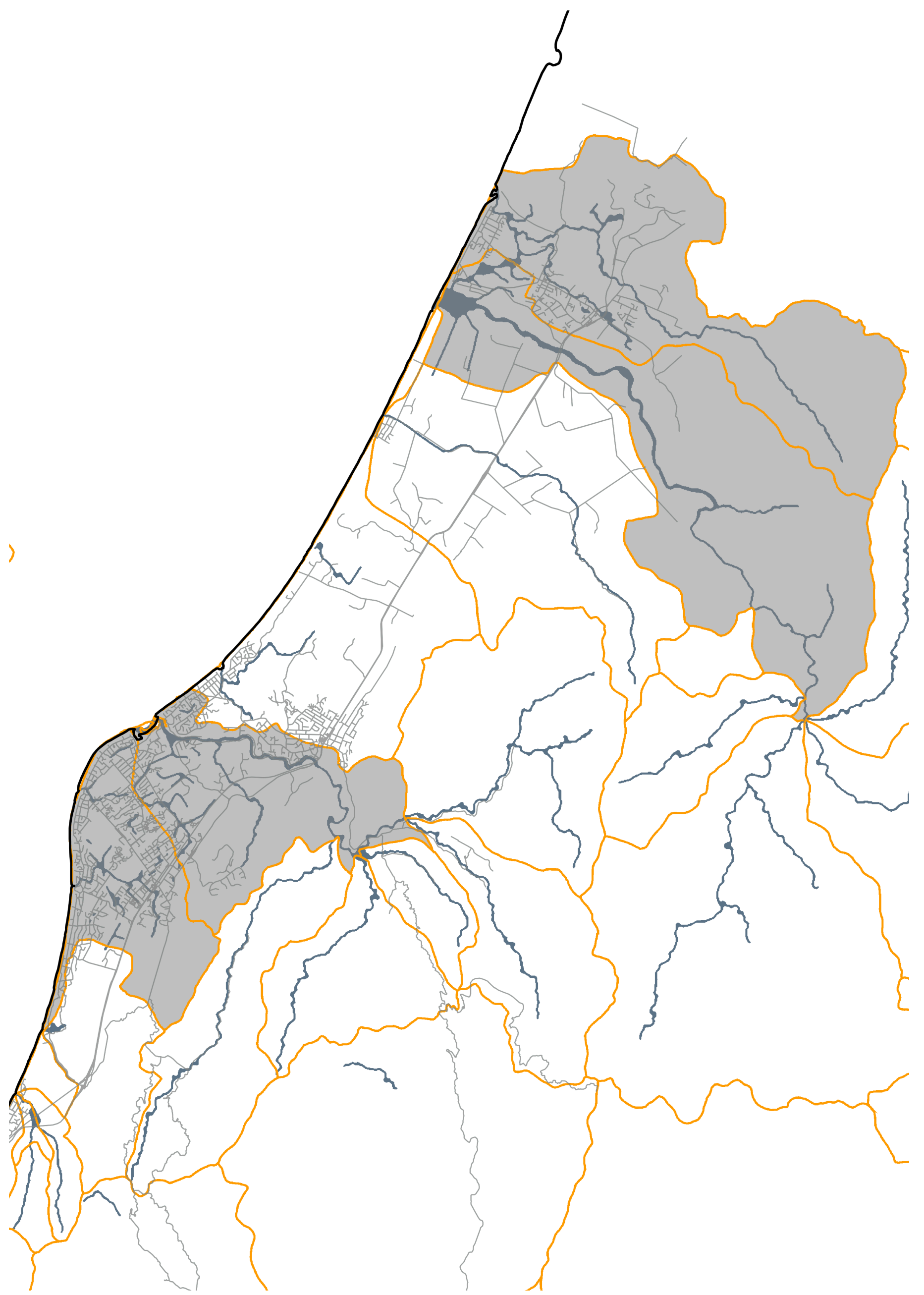

Tig 2.6 // The Four main catchments of the Kapiti Coast, Otaki River catchment, Waikanae River catchment, Waimeha Stream and the Mangaone Stream catchment. Scale 1:100,000 @ A3 


\section{The Rivers}

The Kapiti Coast is broken up into 4 catchments. Otaki River, Waikanae River, Waimeha Stream and the Mangaone Stream with the two largest being the Otaki and the Waikanae River catchments. The larger of the two, the Otaki River collects from a catchment of around $365 \mathrm{sqkm}$ where it begins high on the western side of the Tararua Ranges and flows through deep valleys and gorges out into the floodplain, which is relatively flat and fertile so was used as farmland.

The Waikanae River catchment has more lowland than the Otaki, as it drains from the western foothills of the Tararua Ranges which is why it is smaller than the Otaki only covering 125sqkm. (Flooding Hazard - Kapiti) It is a natural feature of the area and is highly valued by the people around it, but as being a river, there are times at which it is not seen in the same light, in particular when it floods.
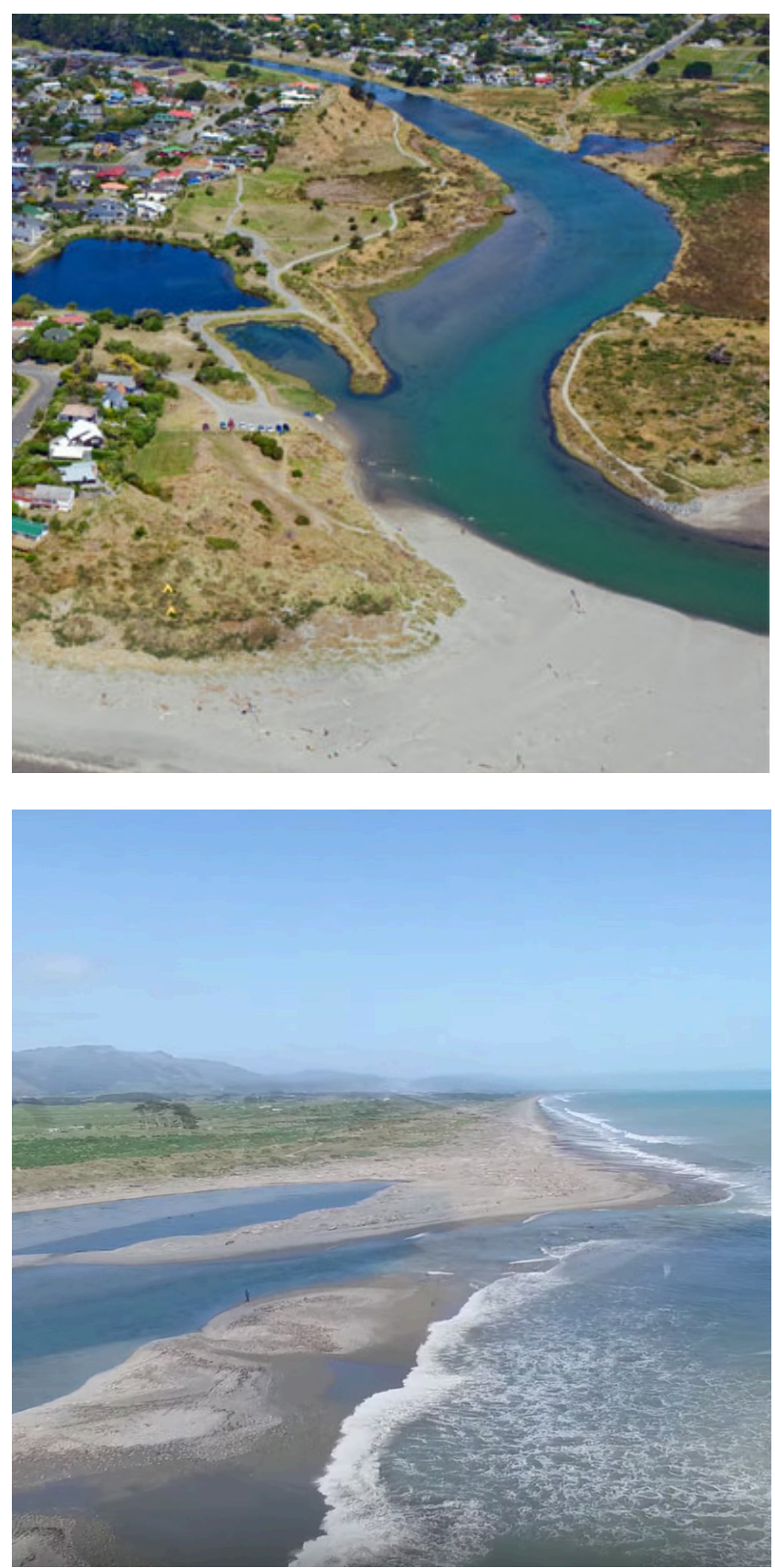


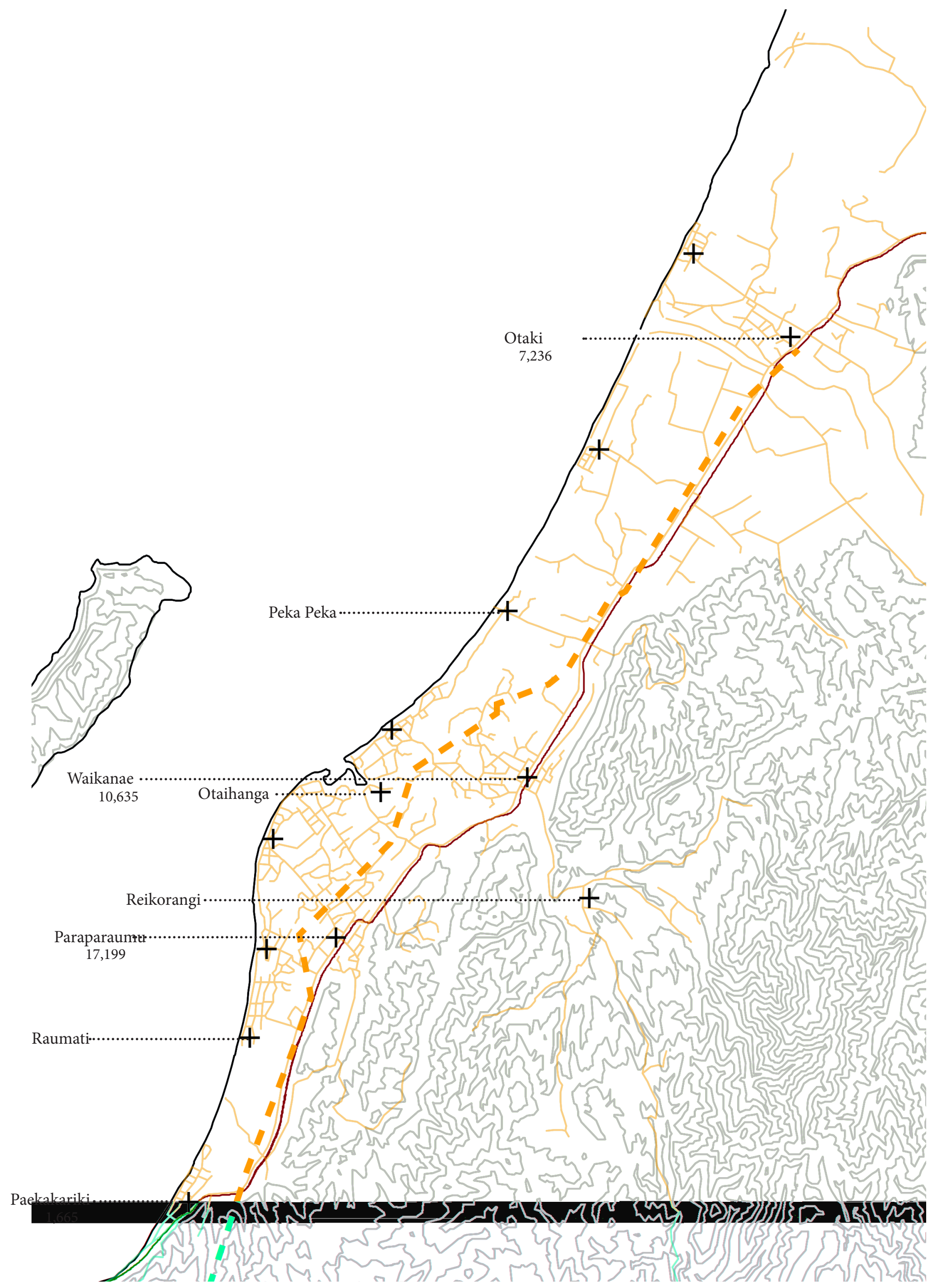

Fig 2.9 // The eight main settlements of the Kapiti Coast and their populations. 


\section{The Settlement}

The original settlers of the Kapiti Coast were the Maori chief Te Rauparaha and his people, who settled on Kapiti Island. It wasn't until the 19th century that Europeans purchased land for permanent settlement but it did not really become significant until the railway went through in the late 19th century. Before this, land was cleared and drained to make way for sheep and dairy farming, and was developed as a series of seaside resorts until the addition of the railway when it took off.

Today it is made up of eight townships along the coast from Paekakariki in the south to Otaki in the north, with a total of 41800 people calling the region home (Statistics NZ). Many of this population commute north and south each day for work along State Highway One which follows the coast from Pukerua Bay to Otaki, a two lane road because of its proximity to the coastline. This is one of the locations where congestion affects road users in high traffic situations, but this issue is in the process of being sorted. The addition of Transmission Gully, and the MacKays to Peka Peka Expressway to the Kapiti landscape will aim to reduce the congestion and reduce the travel time from the north or south through the region.
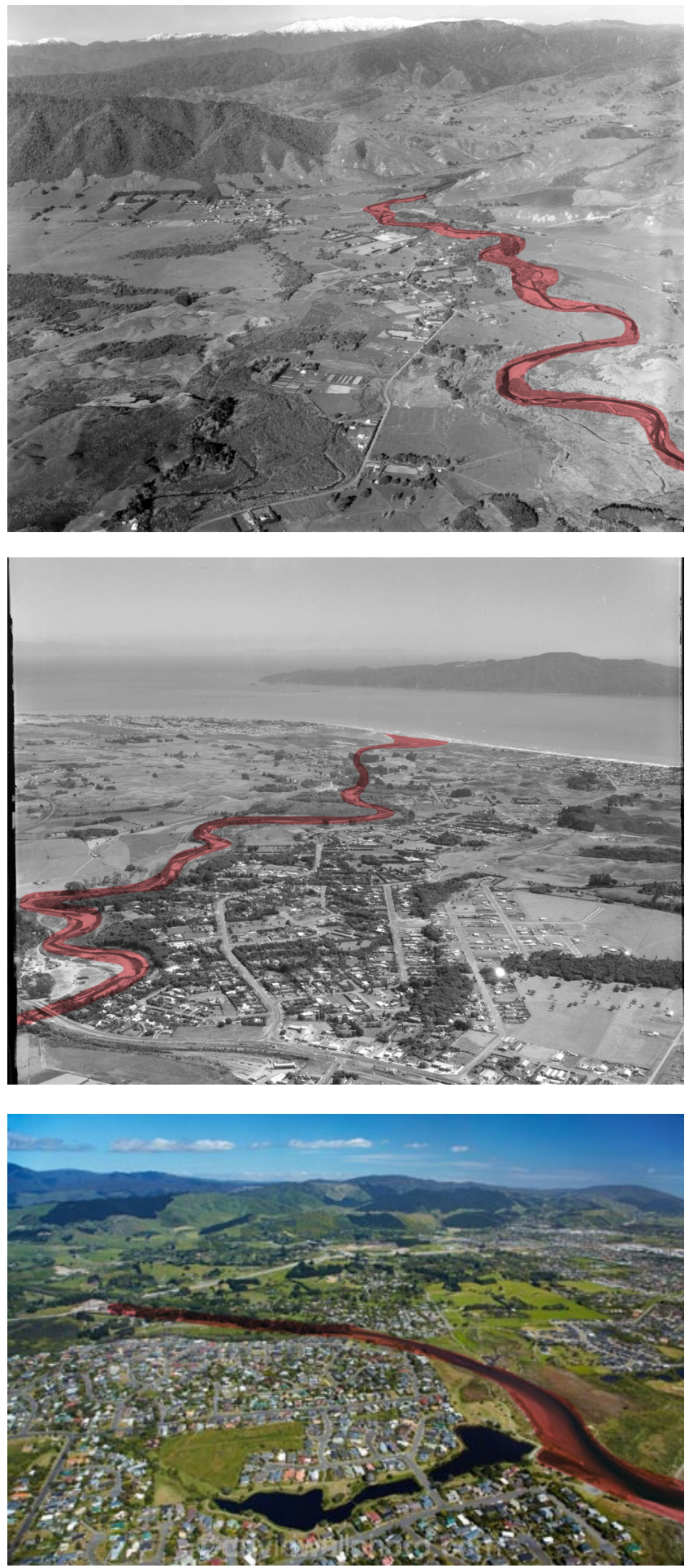


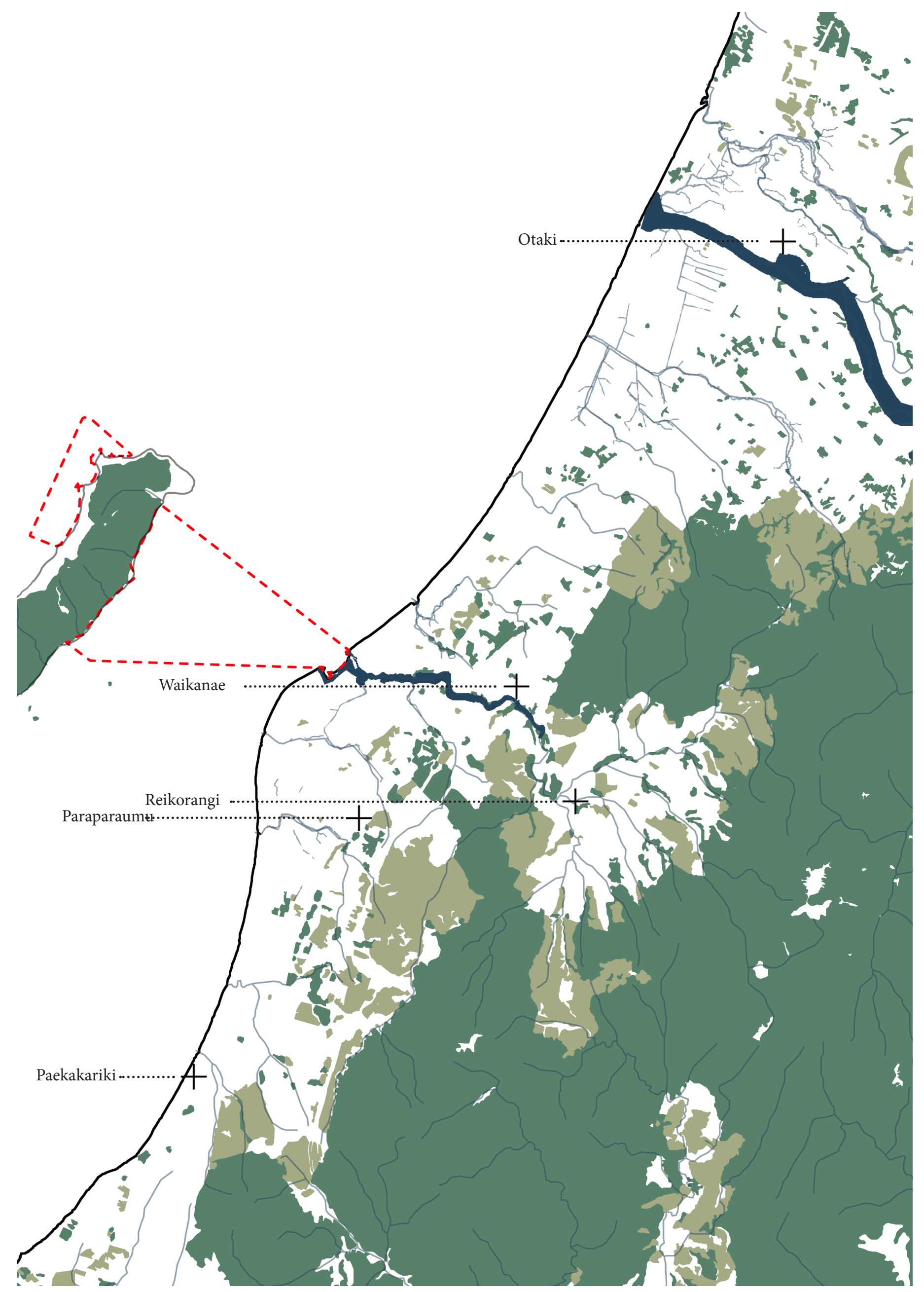

1 Fig 2.13 // Native vegetation and Exotic vegetation of the Kapiti Coast 


\section{Ecology}

Kapiti's ecology, pre settlement of the Europeans consisted of many different typologies, from dune vegetation and swamp forests up and down the coast. Then it was drained and cleared to make way for farming and settlement, and today less than $5 \%$ of the indigenous vegetation remains.

The map opposite shows the extent of native ecology, in the darker green, remaining on the coast, from the protected Kapiti Island to the Tararua Forest Park at the edge of the Tararua Ranges. But between this, the rest is left to farming and urbanisation, of which we can really see the effects of its sprawl in the area of Reikorangi near the source of the Waikanae River. Situated between the Tararua Forest Park and the Paraparaumu Scenic Reserve, its fingers can be seen spreading back into the hills taking more land for farming and settlement.
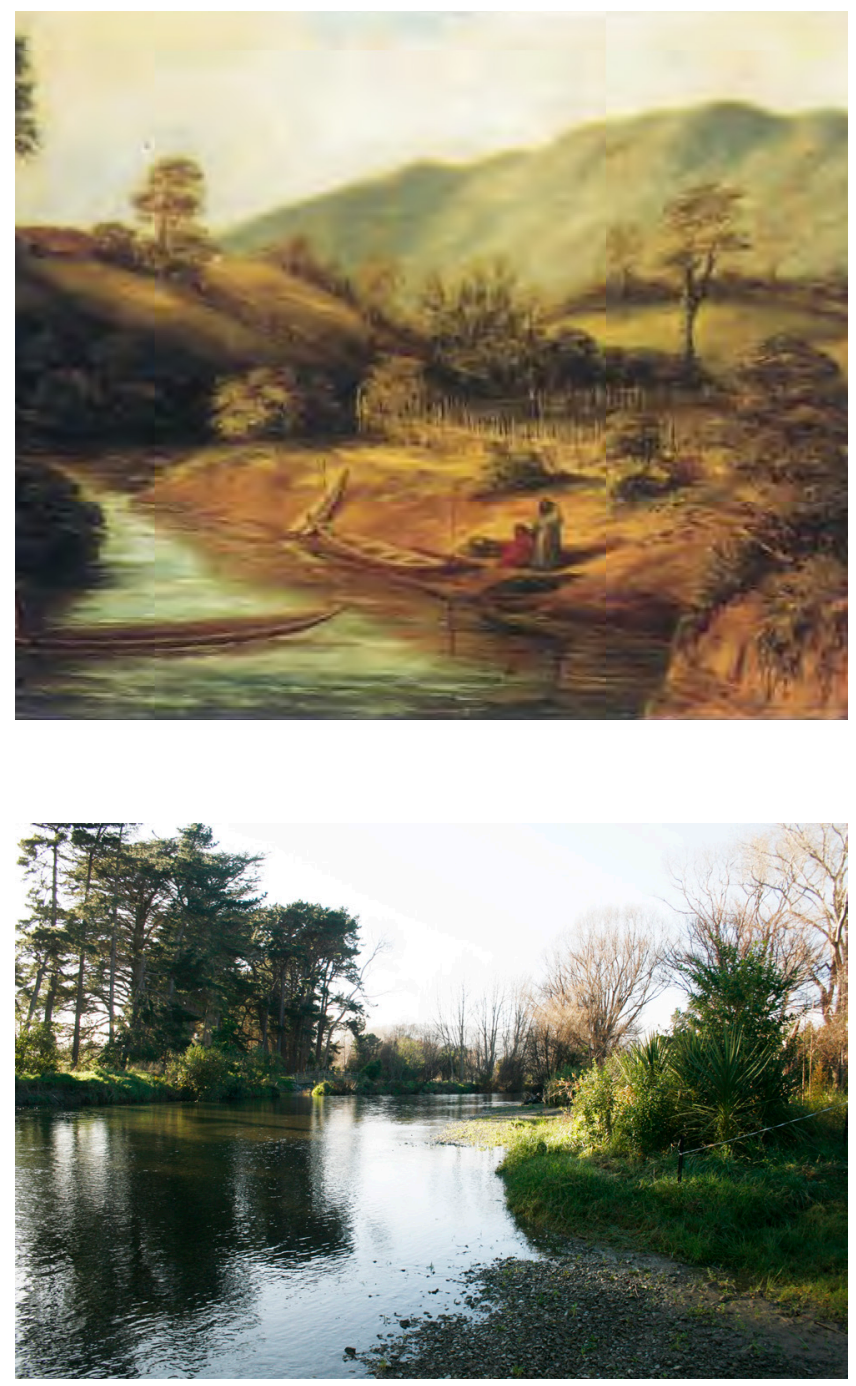


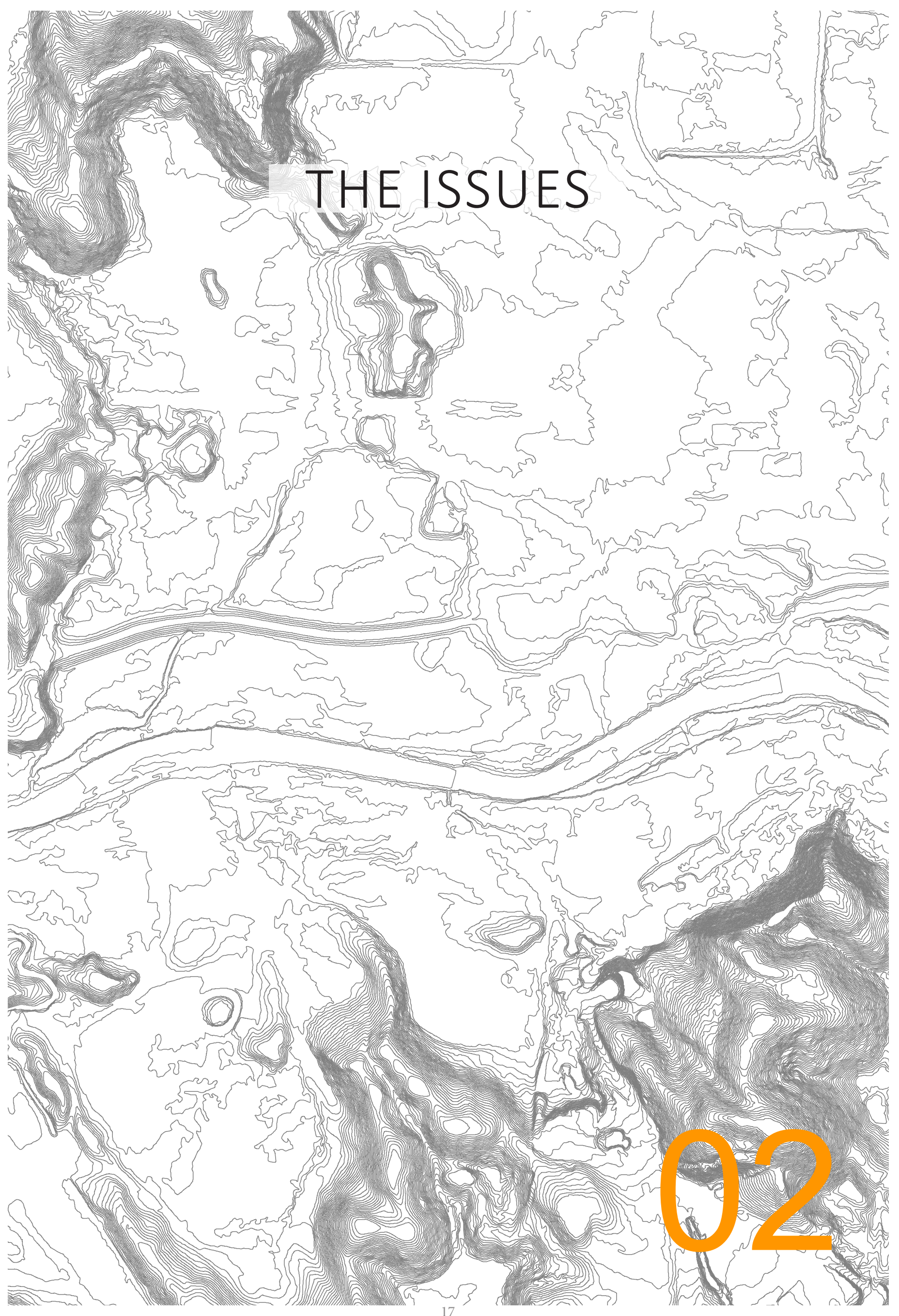




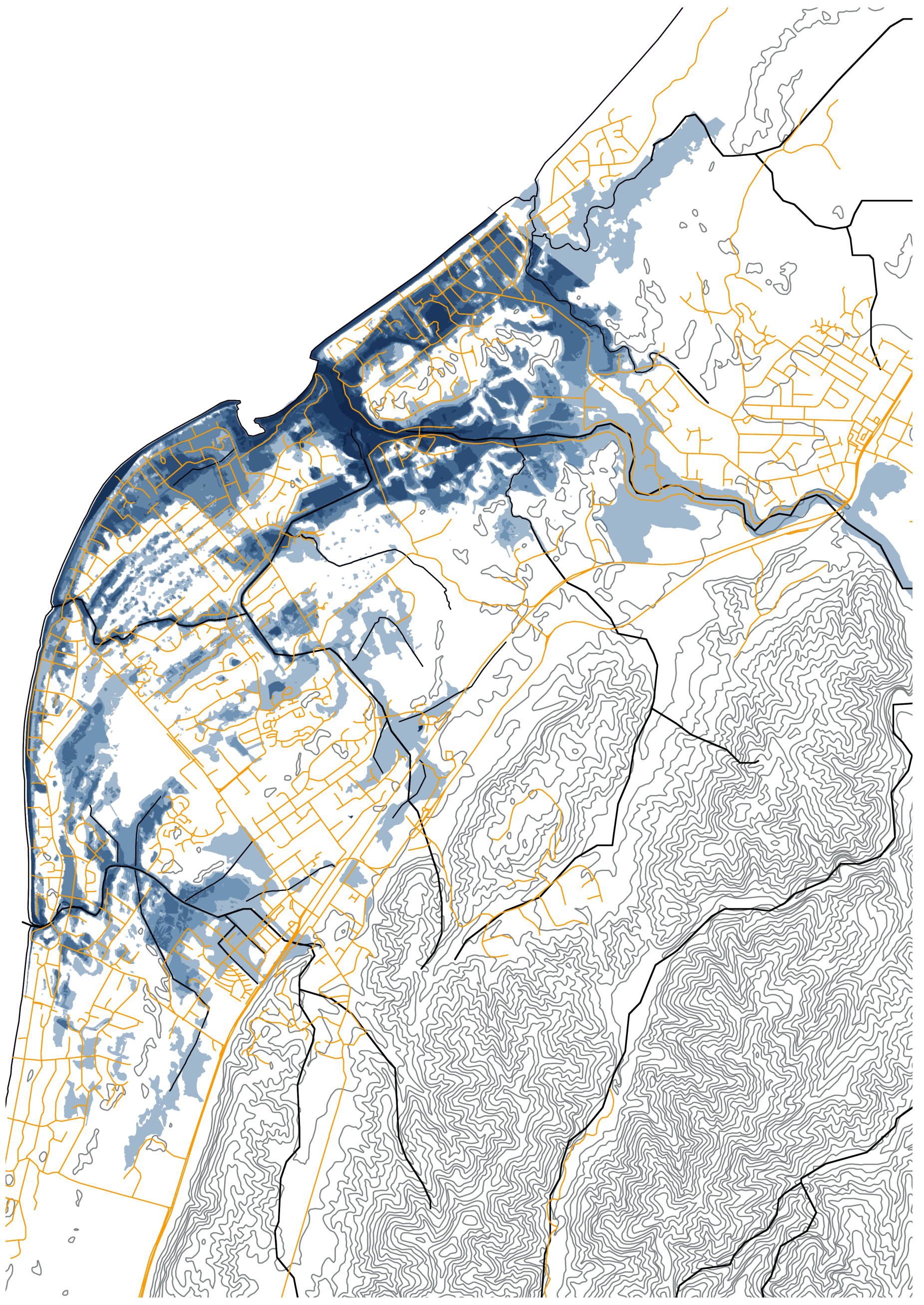

Fig 3.1 // Flooding and a 5 metre sea level rise on the Waikanae River area and Paraparaumu. Darker blue areas are at one meter intervals greater depths generally in 


\section{Flooding}

As the Waikanae River reaches the floodplain, it is kept to its path by stop banks designed and put in place to stop flood waters from reaching houses and business, but often with the Waikanae River this is not the case and the waters break through. In this instance, major floods along the Waikanae River could cause millions of dollars in damages to its surrounding communities.

At the time it was written, the Flooding Hazard Kapiti document by the Greater Wellington Regional Council said, the biggest floods on both the Otaki and the Waikanae Rivers occurred in 1995 and 1998. In 1995 the Waikanae River broke its banks twice and then again the following year with a similar event which was estimated to be a 1 in 50-year event.
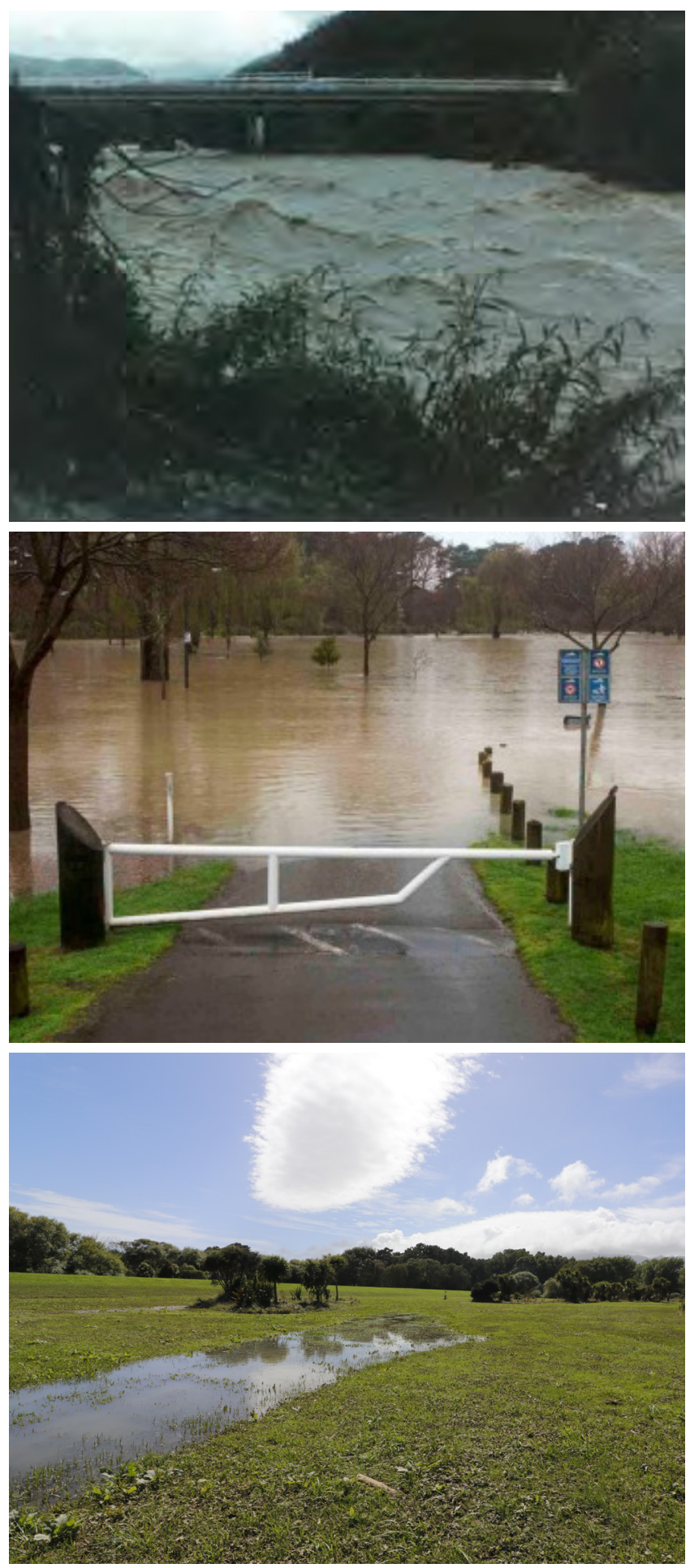


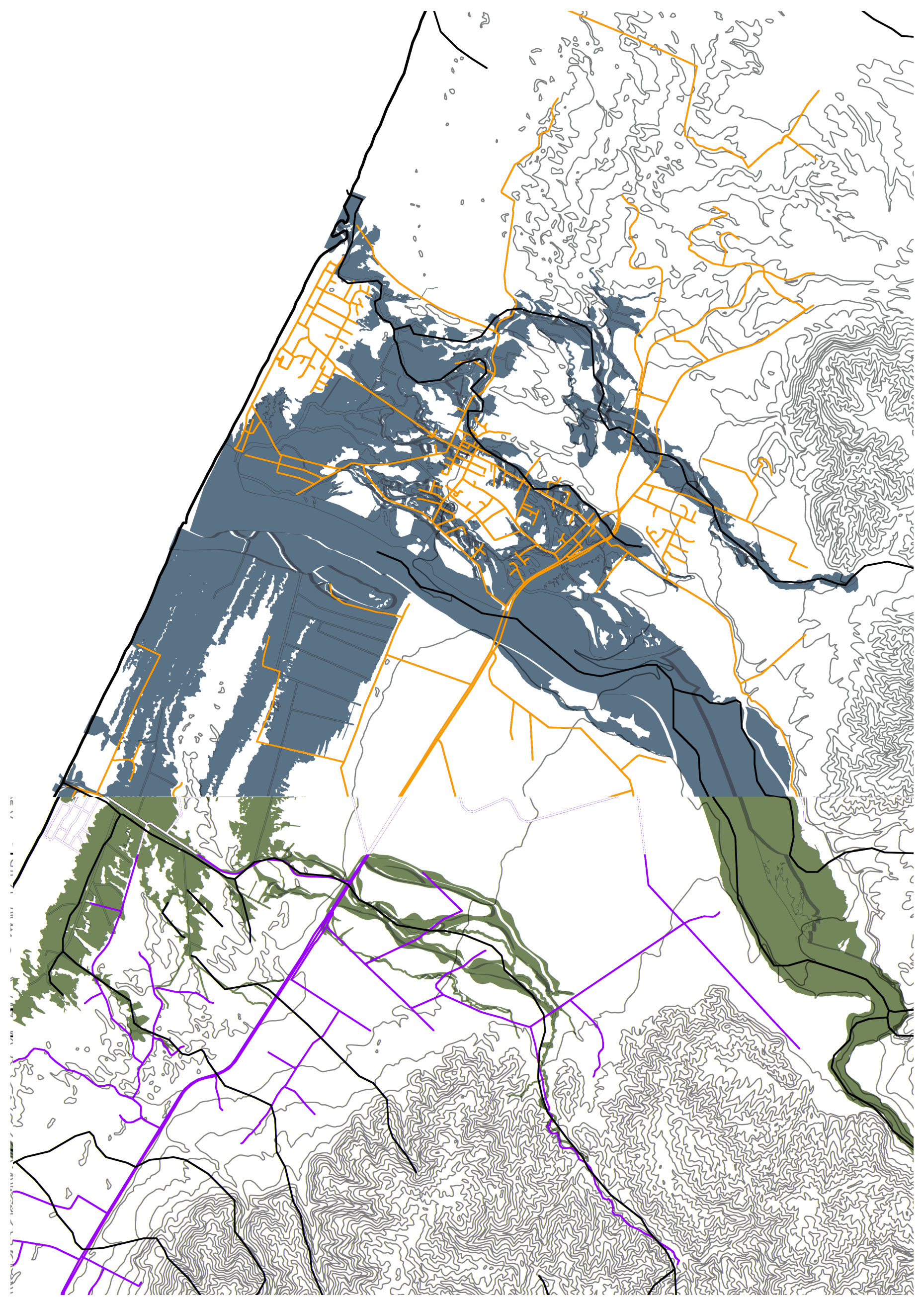

Fig 3.5 // Flooding and a 5 meter sea level rise on the Otaki River. Darker blue areas are greater depths generally in river or stream corridors. Scale 1:50,000 
Again in 1998, even after the addition of measures to ensure it would not happen again, more flooding occurred as a 1 in 30-year event. This time it caused an estimated total of $\$ 2$ million in repairs to homes and businesses. (Flooding Hazard - Kapiti). Influence by humans on the floodplain has resulted in significant changes on the landscape. Forests have been cleared, settlements built and forms of river management have been used. These modifications, combined with the natural flooding of the river create flooding hazards. Even with the protections implemented after the 1955 event, moderate floods continue to cause damage, mainly for settlements in areas that are close to the river corridor. So it leaves residents wondering, "do they live in a flood prone area?" (Waikanae Floodplain Management Plan)
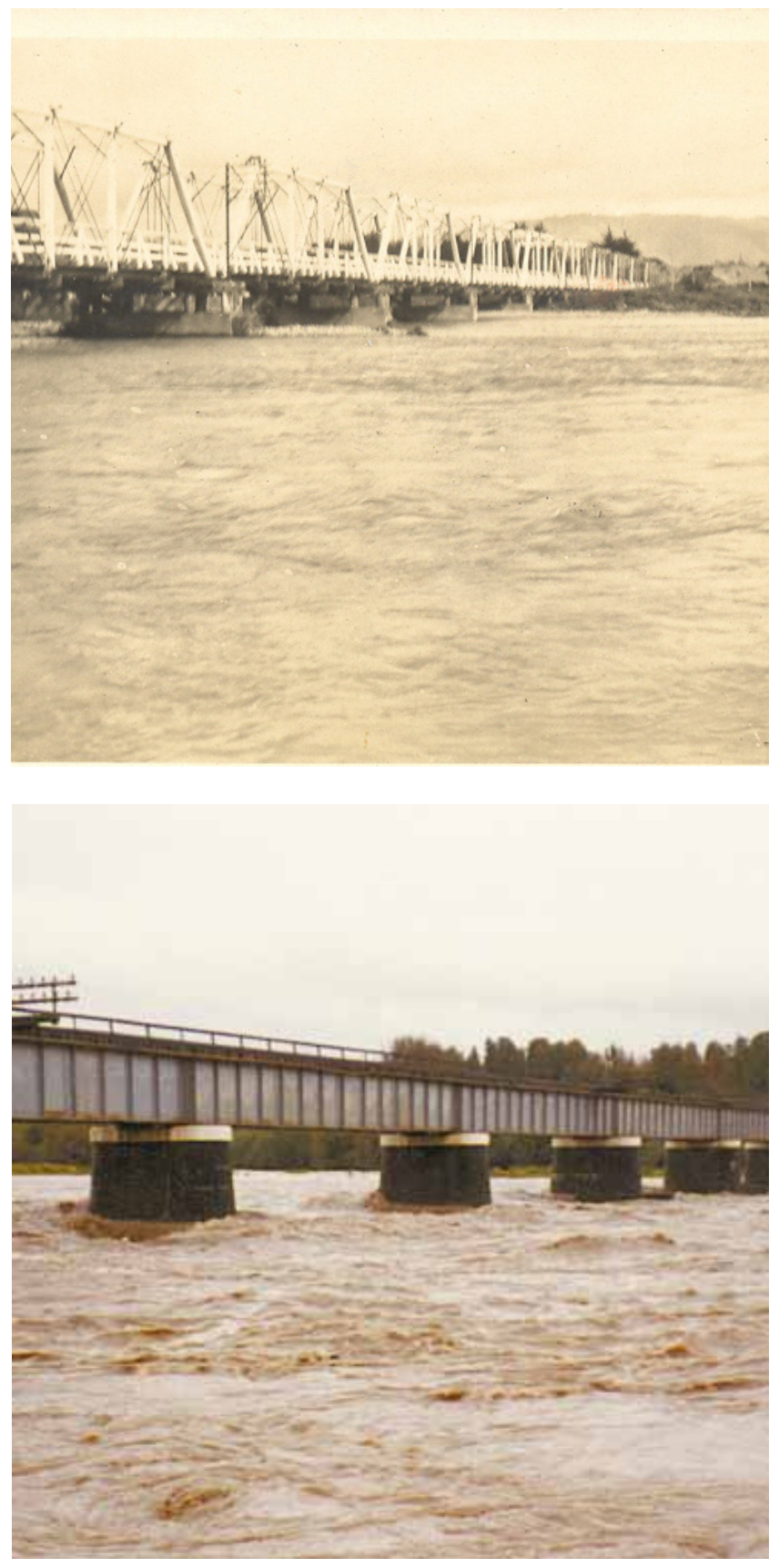


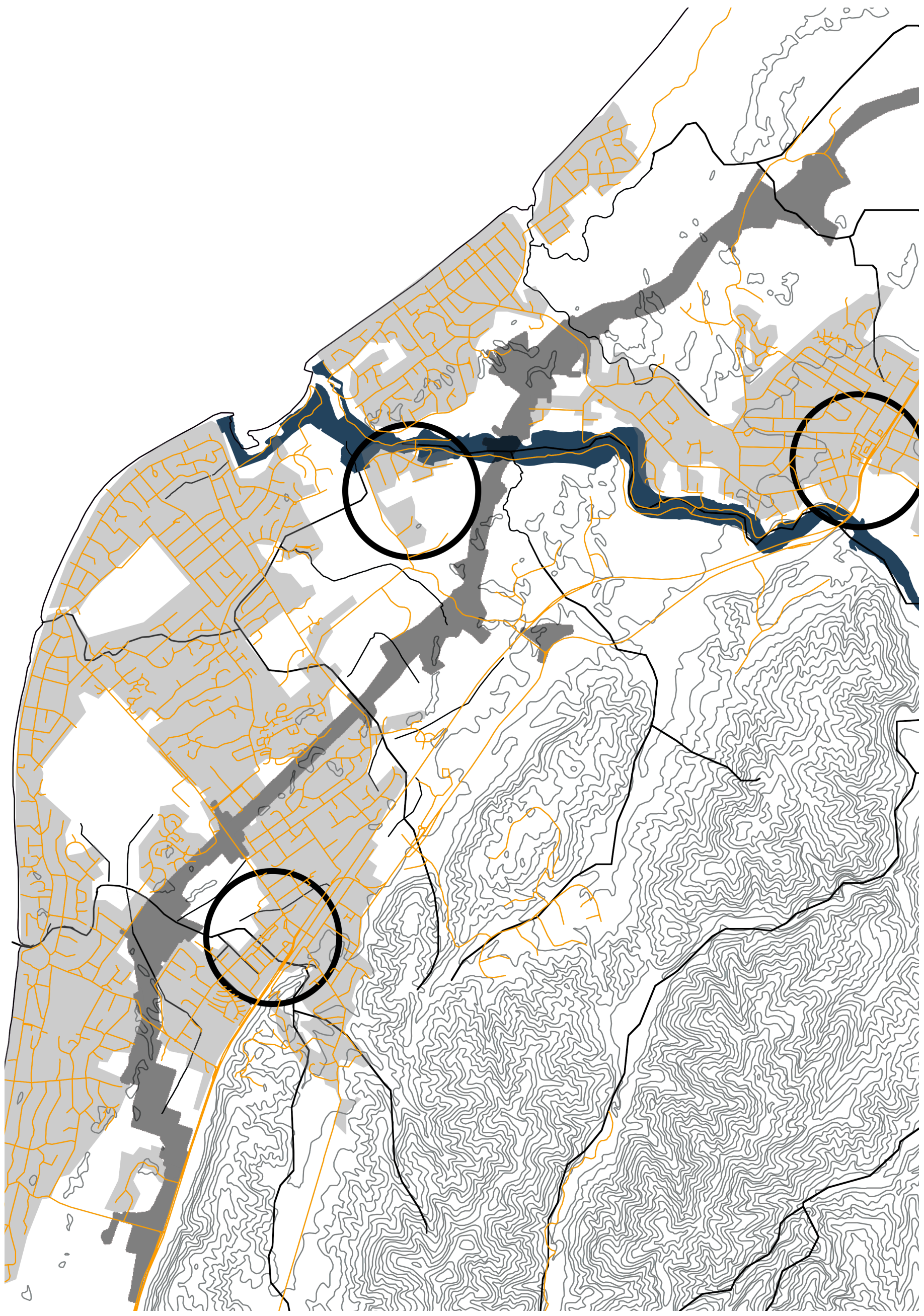

Fig 3.8 // Settlement centres around the Waikanae River, and the MacKcays to Peka Peka Expressway 


\section{Settlement}

There are two settlements that reside along the Waikanae River, the township of Waikanae and Otaihanga. Otaihanga is on the south side of the river and is directly on its banks and directly next to the Waikanae Estuary and the Waikanae River mouth. With a population of 1203 (Population, Dwellings \& Ethnicity | Otaihanga | Profile.Id) the main settlement looks as though it is made up of batches with a small population of permanent residents, but this is merely an observation. It is the worst affected area of the Waikanae River as seen by the flooding in the first few weeks of 2005, 18 houses were damaged requiring residents to be evacuated (18 Homes Flooded North of Wellington - Floods - NZ Herald News). And then hit again more recently in 2016, this time less severe waters rose and filled the Otaihanga domain and closed it Fig 3.3.

Across the river from Otaihanga is Waikanae, a town with a population of 10630 expected to increase to 15000 by 2033 . Waikanae is also affected by the same flooding that Otaihanga gets, as there was once a stream that broke off the Waikanae River that now runs through the township and can be seen in Fig 3.1 as the flooding cut across the township.

With the new expressway going through Kapiti, the estimated population numbers could be very different. With faster and greater access to and from Wellington, more people may move to the Kapiti Coast creating an increase in the need for housing. This could turn Otaihanga into more than just a seaside village. But will they ask the same question as those currently living there, "am I safe from the flood waters?"
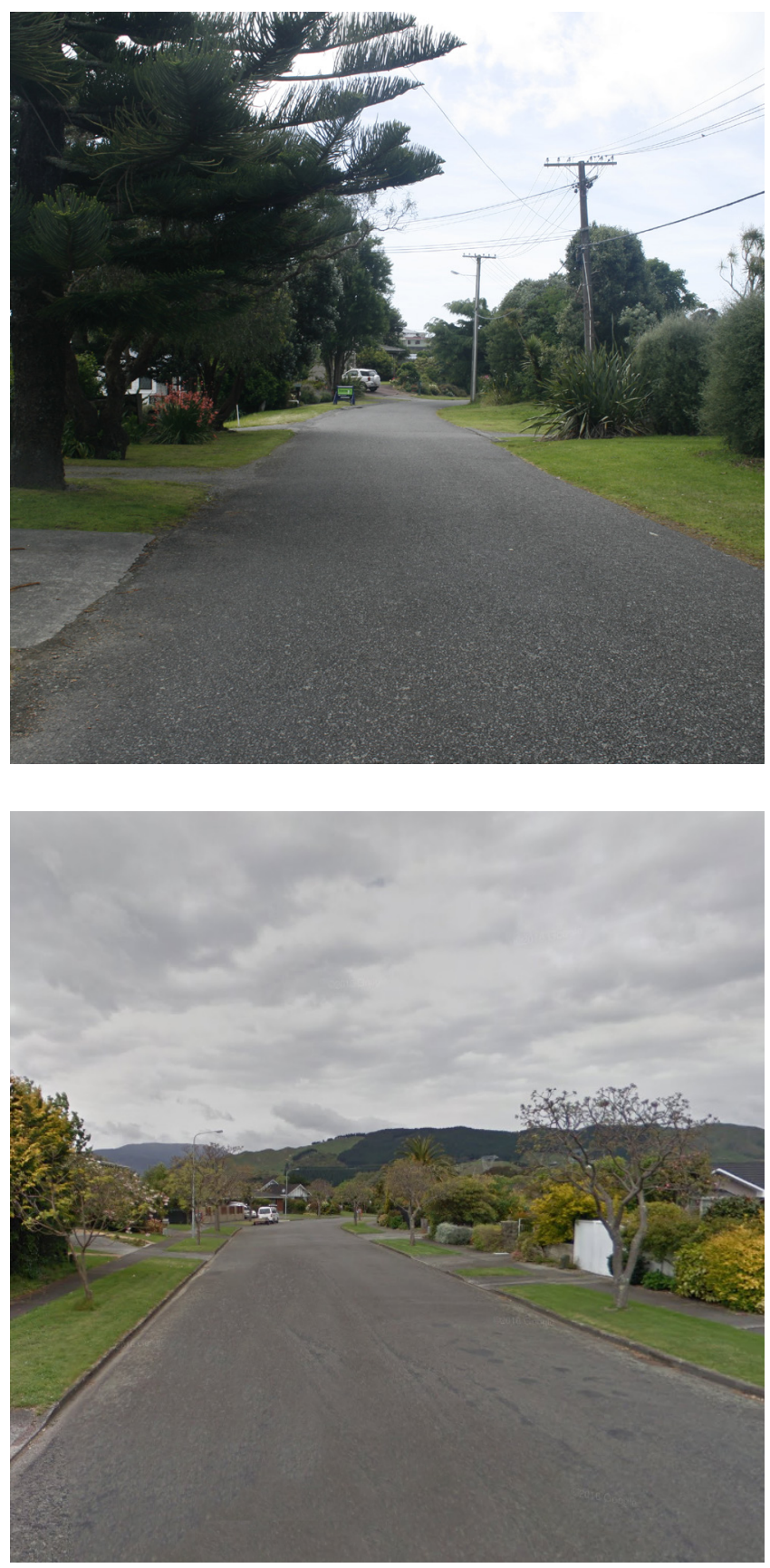

Fig 3.9 // Top image // Otaihanga is a small village mostly made up of batch houses and has a very informal structure.

Fig 3.10 // Bottom image // Waikanae street structure. 


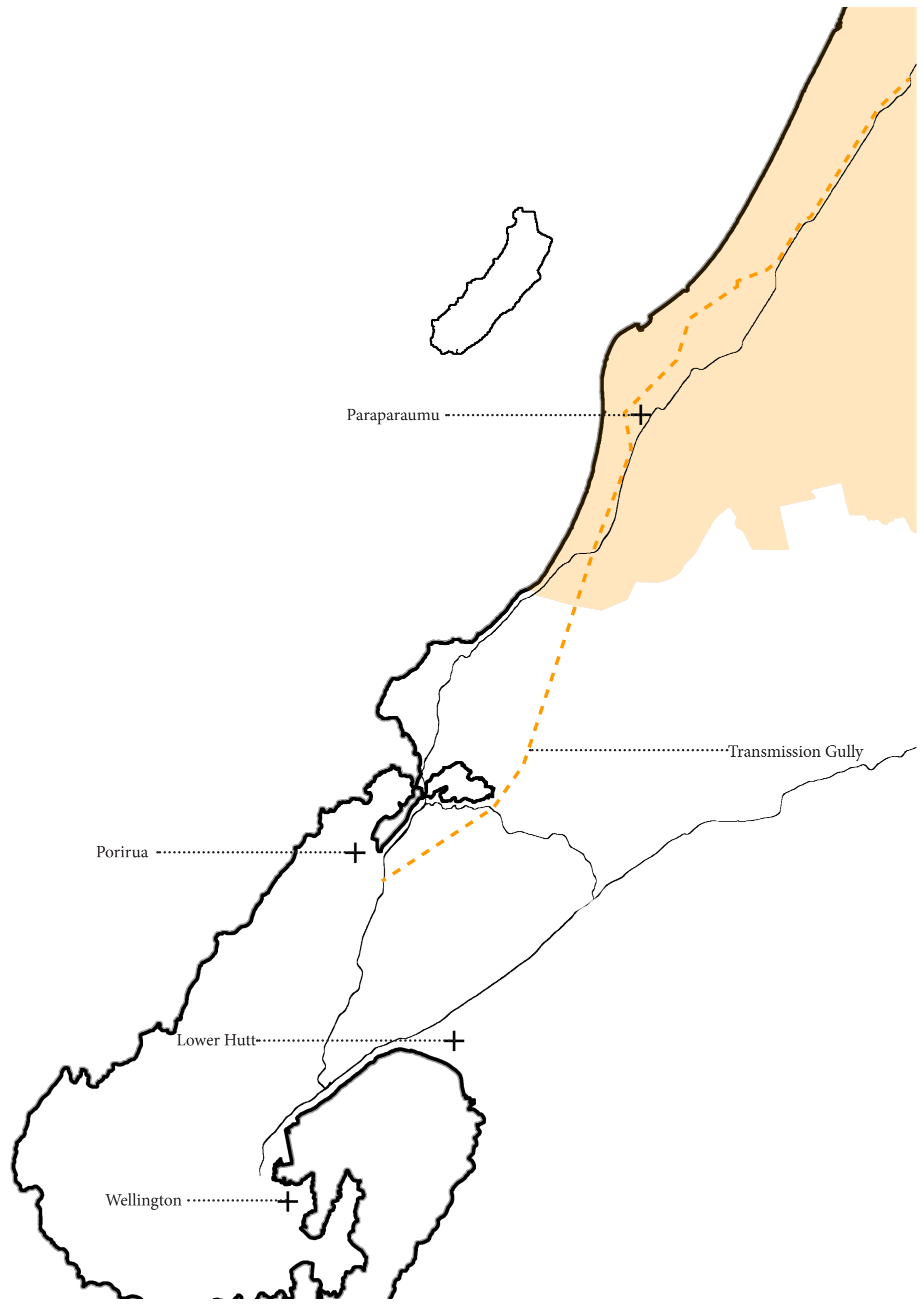

Fig 3.11 // Opposite page // Expressway map from Porirua through Paraparaumu, study area Kapit Coast in orange.

Scale 1:2250,000

24 


\section{Mackays to Peka Peka \\ Expressway}

The Mackays to Peka Peka Expressway is a long awaited addition to the Wellington landscape, and will open up a key corridor to the north of Wellington. A critical link to the lower North Island to provide safer, more efficient and reliable access to the capital Wellington. For the region of Kapiti, they will reap many of the benefits that it will provide, including reduced congestion on local roads with it now transferred to the expressway. A shorter and modern road will reduce travel times and result in safer trips. Kapiti's economy will benefit from more jobs and better access to them and beyond because of the expressway. But, with such a large obstruction across the landscape being created, could this create some potential negative effects on the flooding situation that is current in Kapiti and divide a special corridor along the Waikanae River? 


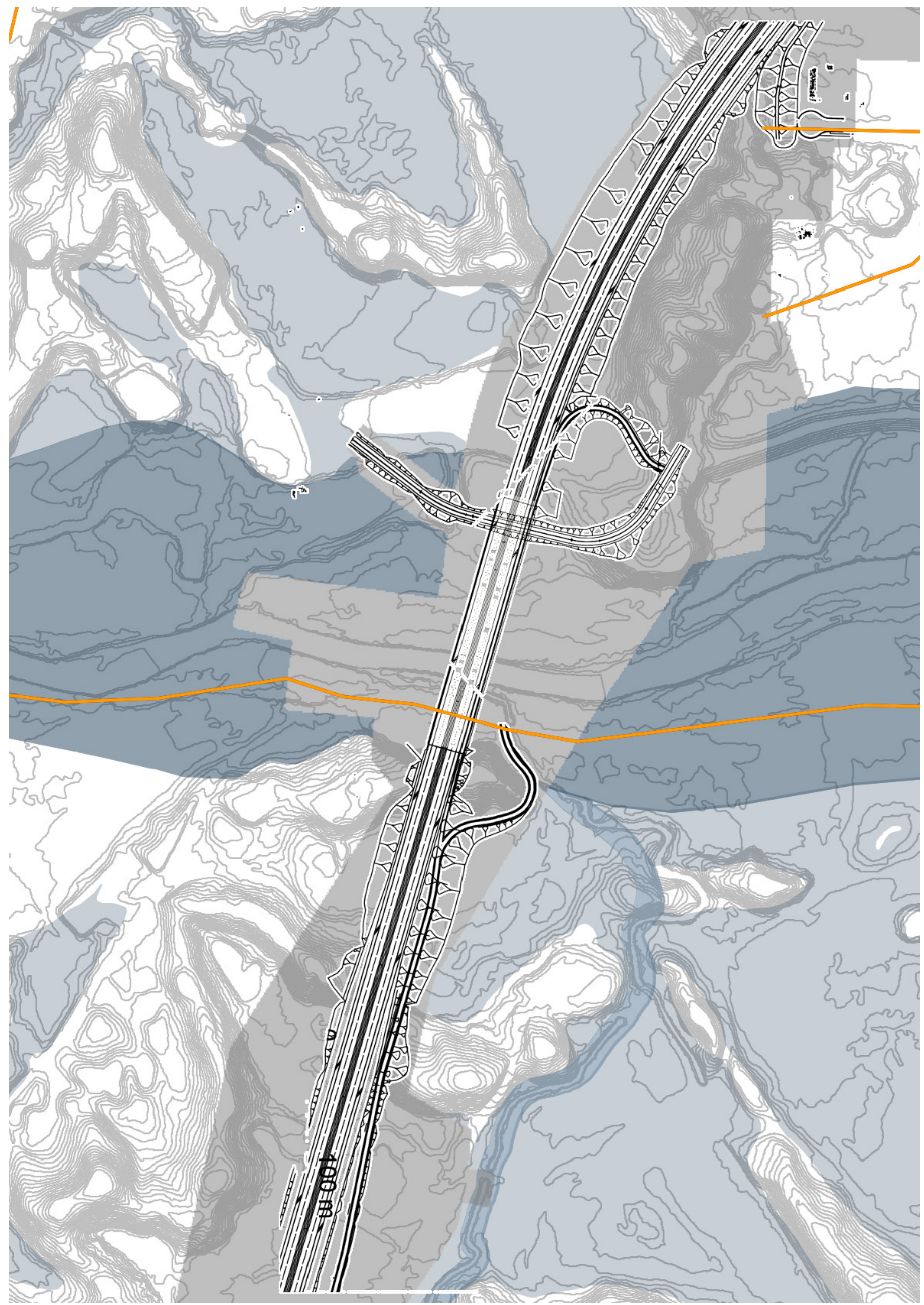

Fig 3.12 // Plan of bridge over the Waikanae River for the MacKcays to Peka Peka Expressway adapted from NZTA documentation. 


\section{The Expressway}

There was a concern, that with the addition of the MacKays to Peka Peka part of the expressway that crosses the Waikanae River, just east of Otaihanga, may cause additional damage during a flood event. The placement of the 180-meter-long bridge over the Waikanae River could be a large barrier across the river holding flood waters back. With the right combination of systems, this could help with flooding, moving the water out across the catchment and holding it. But has this been taken into consideration by the planners of the expressway? The 180-meter-long bridge will span the river corridor and its eight support columns have been specifically chosen so as to not affect the flow during a flood.

Perhaps it could have been designed to aid in the flood protection efforts as it is right next to Otaihanga, which is severely affected by floods, which could have been more beneficial to them. This could have been particularly helpful as Otaihanga may flourish with the addition of the expressway to Kapiti, providing greater access to and from Wellington more people may flock to Kapiti to live creating an influx in houses and the need for them. However, with more houses comes more potential damage that can be caused by the flood.
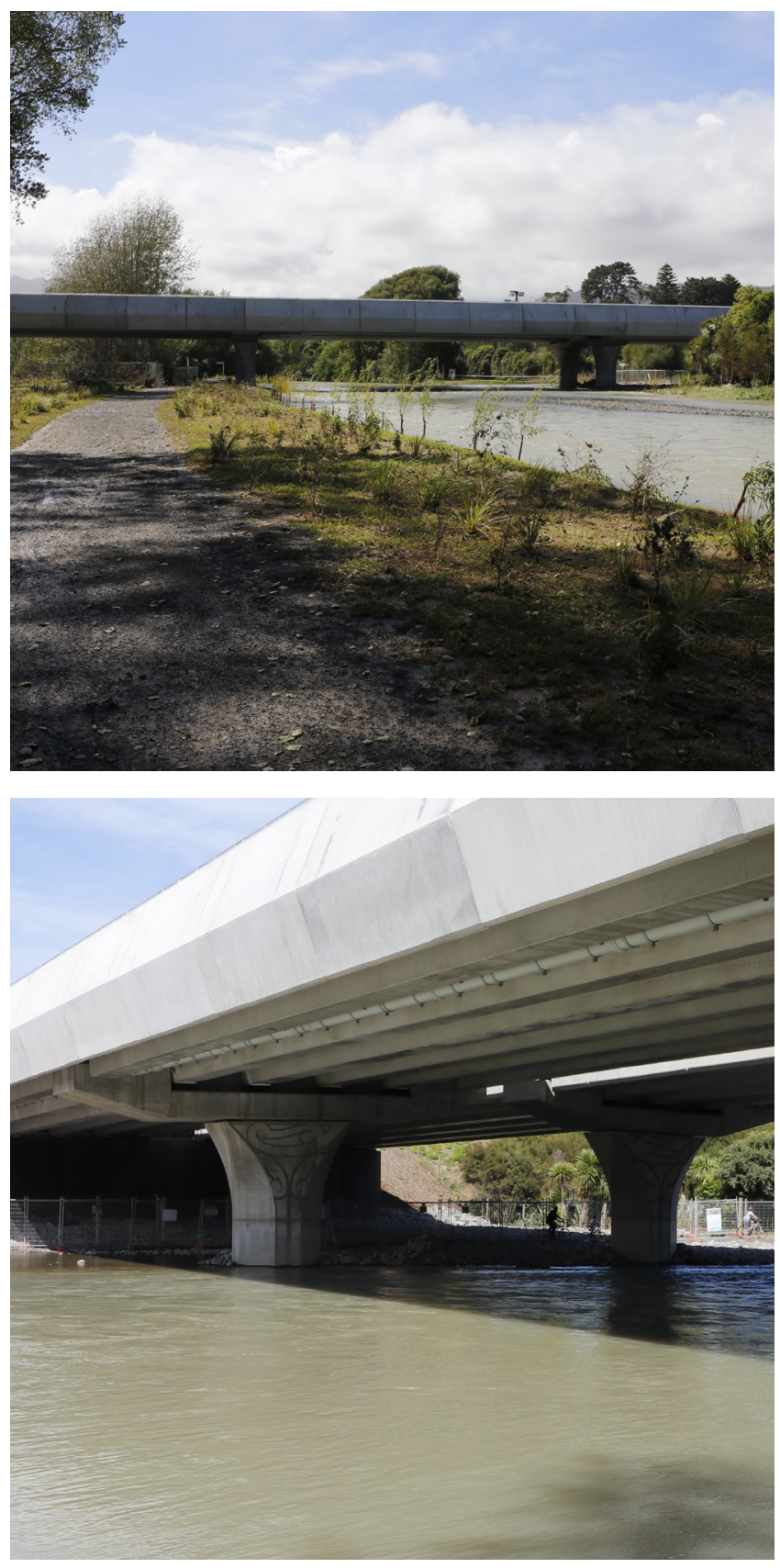


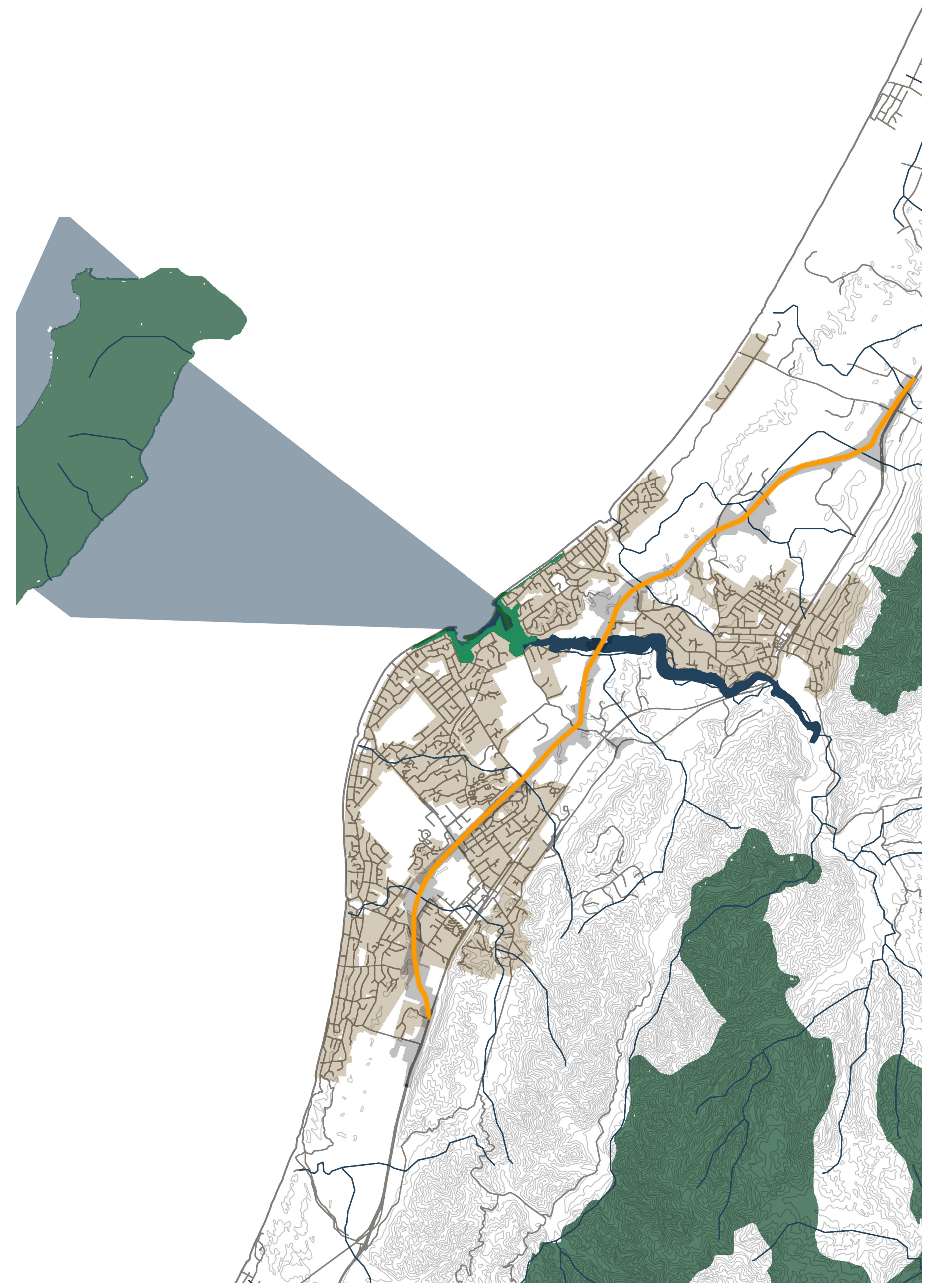

T Fig 3.15 // Flooding and a 5 meter sea level rise on the Otaki River. Darker Blue areas are greater depths generally in river or stream corridors. 


\section{Severing the corridor}
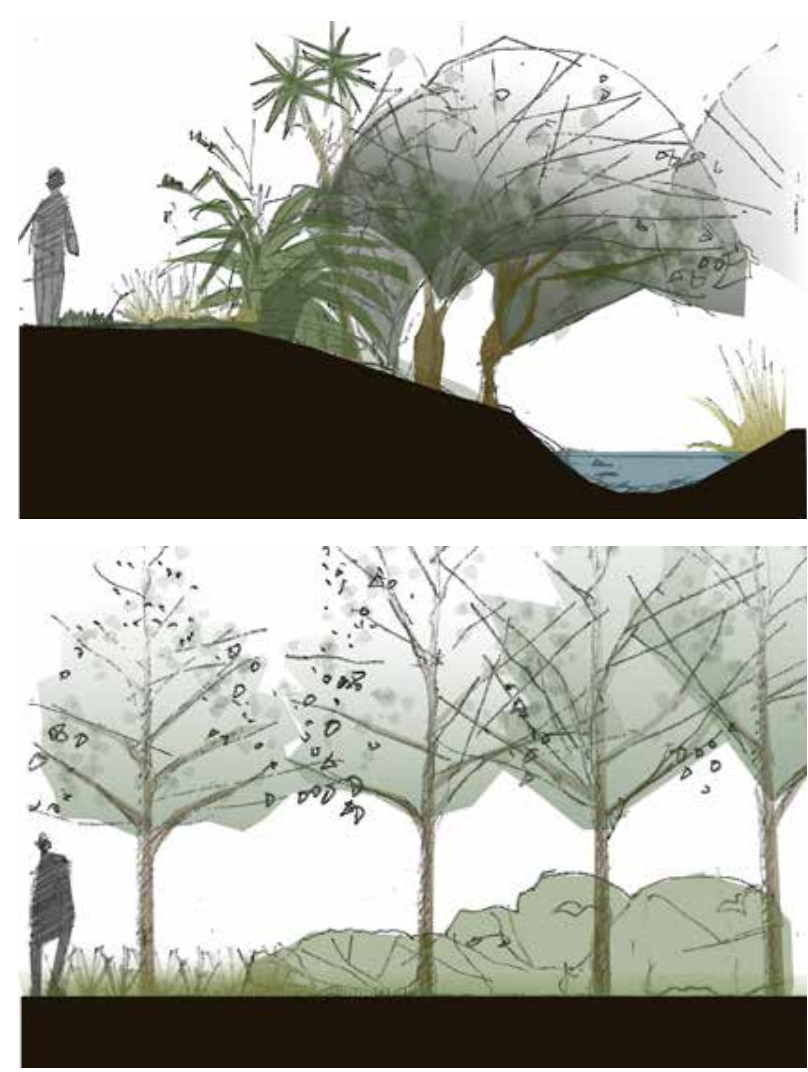

With the placement of the expressway going across the river, it creates a cut, dividing east and west from each other. This would also cut through the mountains to sea ecological corridor, which is discussed in more detail later in the research, possibly creating a barrier against the native fauna and flora. But, as part of the planning for the expressway and the crossing of the Waikanae River plans were put in place to replace and enhance any vegetation that had to be removed as part of the construction of the expressway. So there may be a small scar across the ecological corridor but it will be beneficial to it due to those plans.
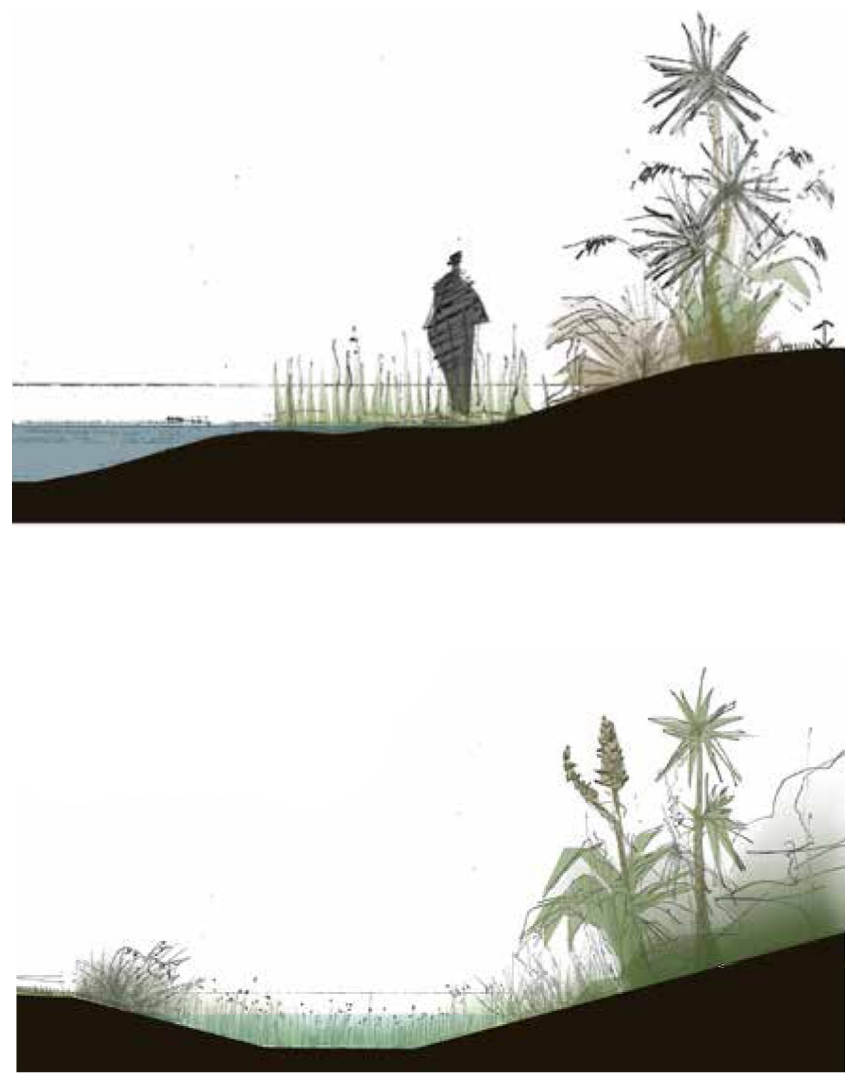

The solutions above presented by the NZTA are examples of landscape planting along the express way. They work as solutions for this project but have minimal effect on the Waikanae River as they are only localised to the expressway. But what would happen if they expanded along the river too, creating a more comprehensive planting plan?

Fig 3.16 // Top Left // Riparian planting, Urban and Landscape Design Framework for Mackays to Peka Peka Expressway Fig 3.17 // Bottom Left // Specimen Trees under planted with ground cover, Urban and Landscape Design Framework for Mackays to Peka Peka Expressway

Fig 3.18 // Top Right // Wetland/Storm water Pond Planting, Urban and Landscape Design Framework for Mackays to Peka Peka Expressway Fig 3.19 // Bottom Right // Storm water swales, Urban and Landscape Design Framework for Mackays to Peka Peka Expressway

Source: http://www.nzta.govt.nz/assets/projects/mackays-to-peka-pekaapplication/docs/management-plan-approved-landscape-part-3.pdf 


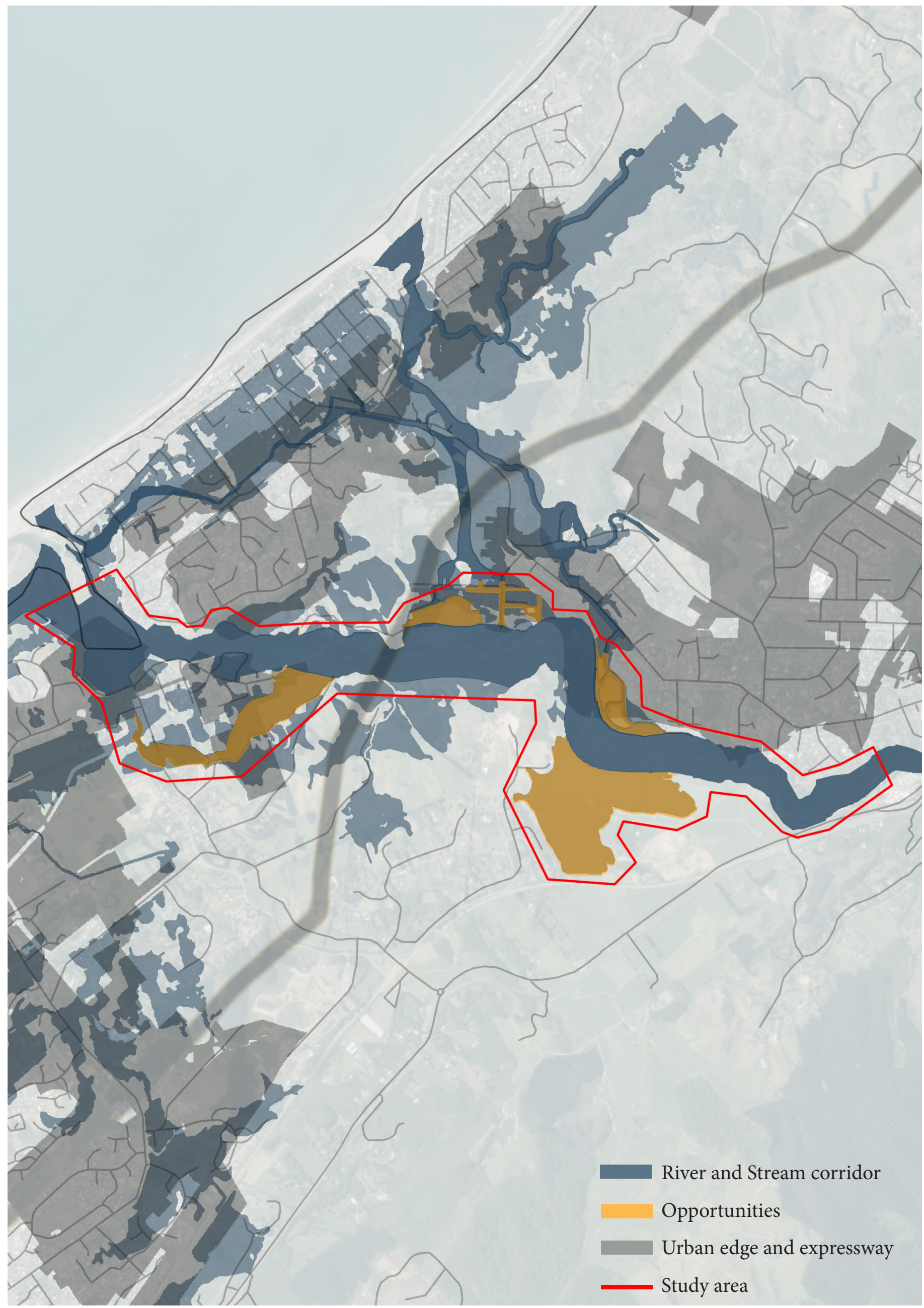

Fig 3.20 // Opportunities map. Restricted by the urban edge along the north side of the river. Opportunities in yellow are seen as the worst effected areas of the river corridor and so have been selected as initial sites. 


\section{Evaluation}

The purpose of the site background and issue analysis was to gain a better understanding of the site to inform design responses later on. The process of analysis has covered a range of areas that were developed through initial hunches and has confirmed them and brought out some opportunities and issues to work with.

Flooding in Kapiti has been an issue for residents from the time they settled and changed the river form. So there is potential here to design for this, and aid the continuing settlement of the site. Kapiti now has a huge potential with the addition of the expressway and Transmission Gully for the landscape to grow. From the review of technical plans and documents from the Wellington City Council and New Zealand Transport Agency it seems the opposite, many factors of the design have been carefully put in place to protect and enhance the natural landscape it goes through, this is also the case for the river as it has been taken into consideration that the river floods and it is important that flow is not disrupted.

The mapping and diagramming have confirmed and highlighted the issues and opportunities that can be used to inform initial designs and through to the final design. 


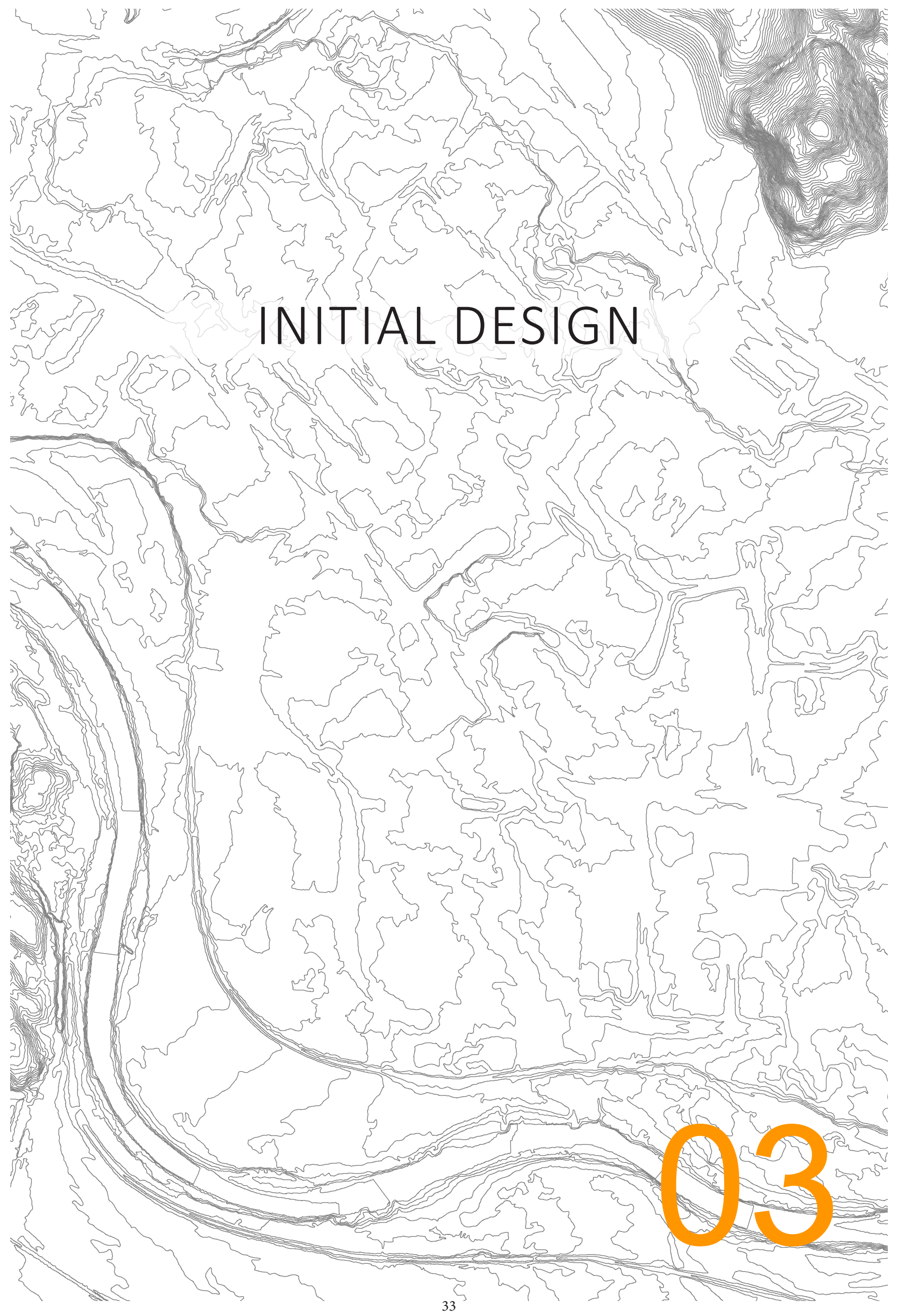




\section{The Archipelago}

In the process of creating some basic flooding maps of the Kapiti Coast to understand what the water is doing to the site, it occurred that what if this wasn't just a flood but a rise in the sea level? This developed a series of designs that looked at the reconfiguration of the coastal settlements into something more resilient to the changes that would eventually happen. These settlements would begin to reconfigure by moving to higher areas of land forming smaller close knit groupings of houses.

Sea level rise would take many years to take complete effect giving time to implement changes, rearranging communities to designated high ground areas across Kapiti. This would form smaller island communities with fewer residents than normal communities and built to be somewhat selfsustaining due to the reduced access that rising seas may create.

Through the exploration of this scenario, it became increasingly apparent that life like this would not work for everyone. The lack of access would become an issue for a region like Kapiti where a number of the population of the area is aging and are not as active anymore. So the exploration became a potential end result which later iterations would look at what would come before to produce these. 

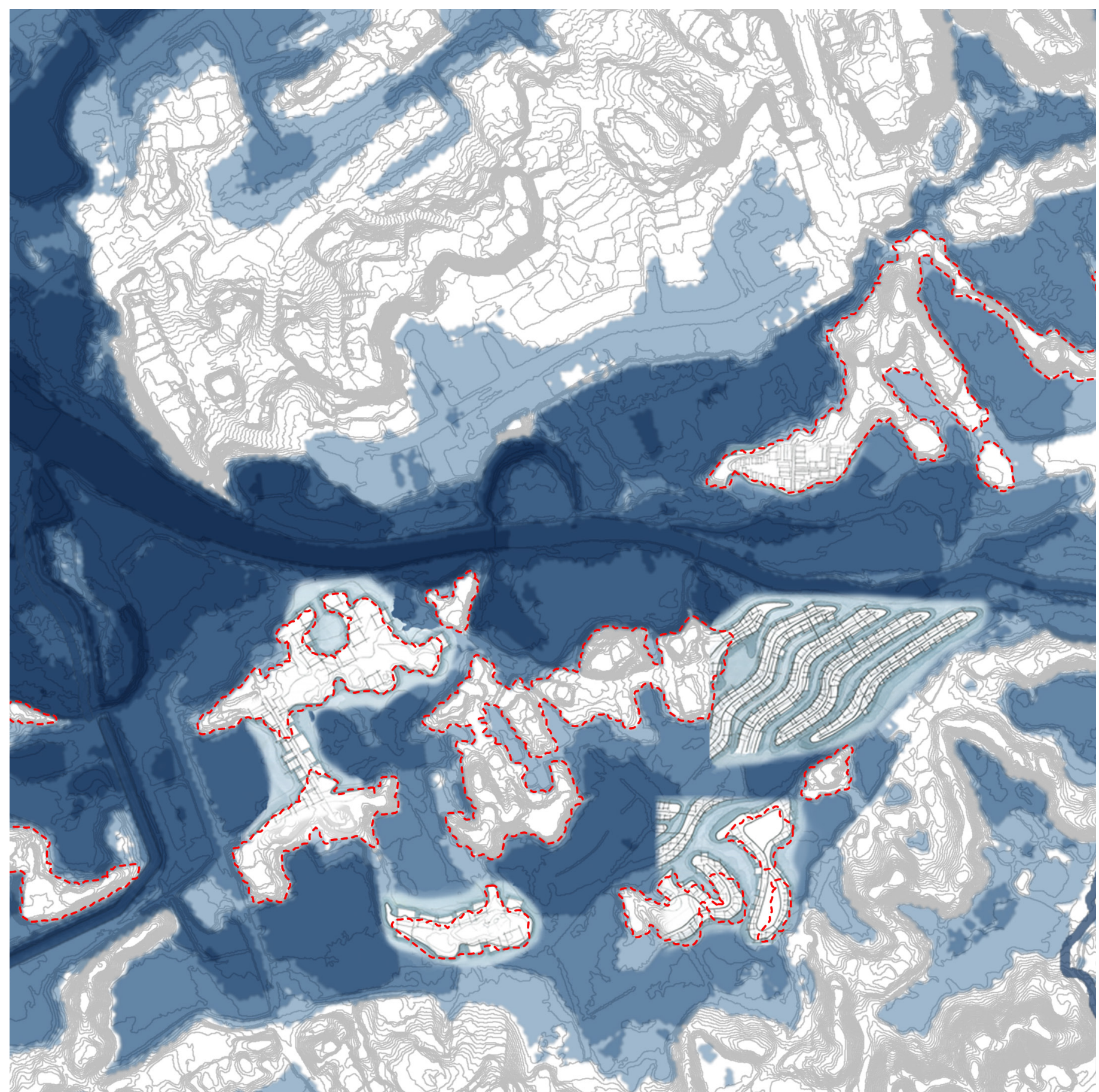

窝

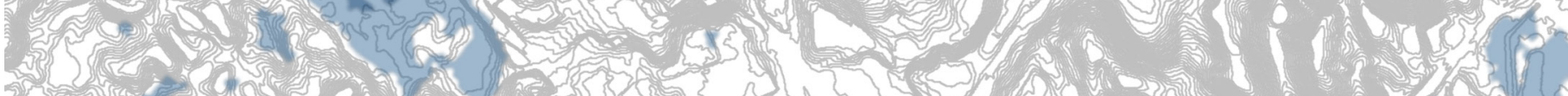
1). (5)

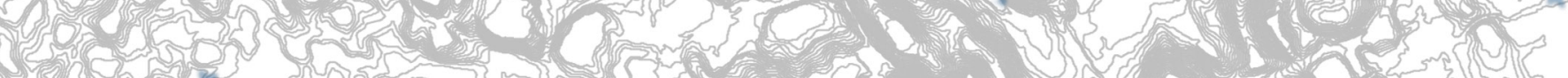
(2)



Fig 4.1 // Initial design location map, highlighted areas in red are existing landforms tested through design, un highlighted areas are constructed landforms 


\section{Cut Off}

Initial thoughts looked at the small chain of islands that would be created by the rising waters, once waters had risen access to these locations would be cut off and alternate modes of transport would have to be looked into. As well as the lack of access basic resources may also be cut off, power, water, communication even food may not be readily available any longer and water collection tanks and community gardens may be required to aid in resident's survival. The hope would be that as everyone on these islands is under the same situation they would band together and survive.

Upon further reflection and considering that a large percentage of Kapiti population is aging, areas like these would not be feasible to sustain people. Many people may not last long having to boat to a car and then to work or even to live so isolated from certain what we may call today as basic resources. This means for the continuing exploration of these initial designs access to the four basic resources would have to stay a priority. Some elements could still be used in later iterations as in flood or even sea level rise events some disruptions to these resources could occur for short periods of time. 


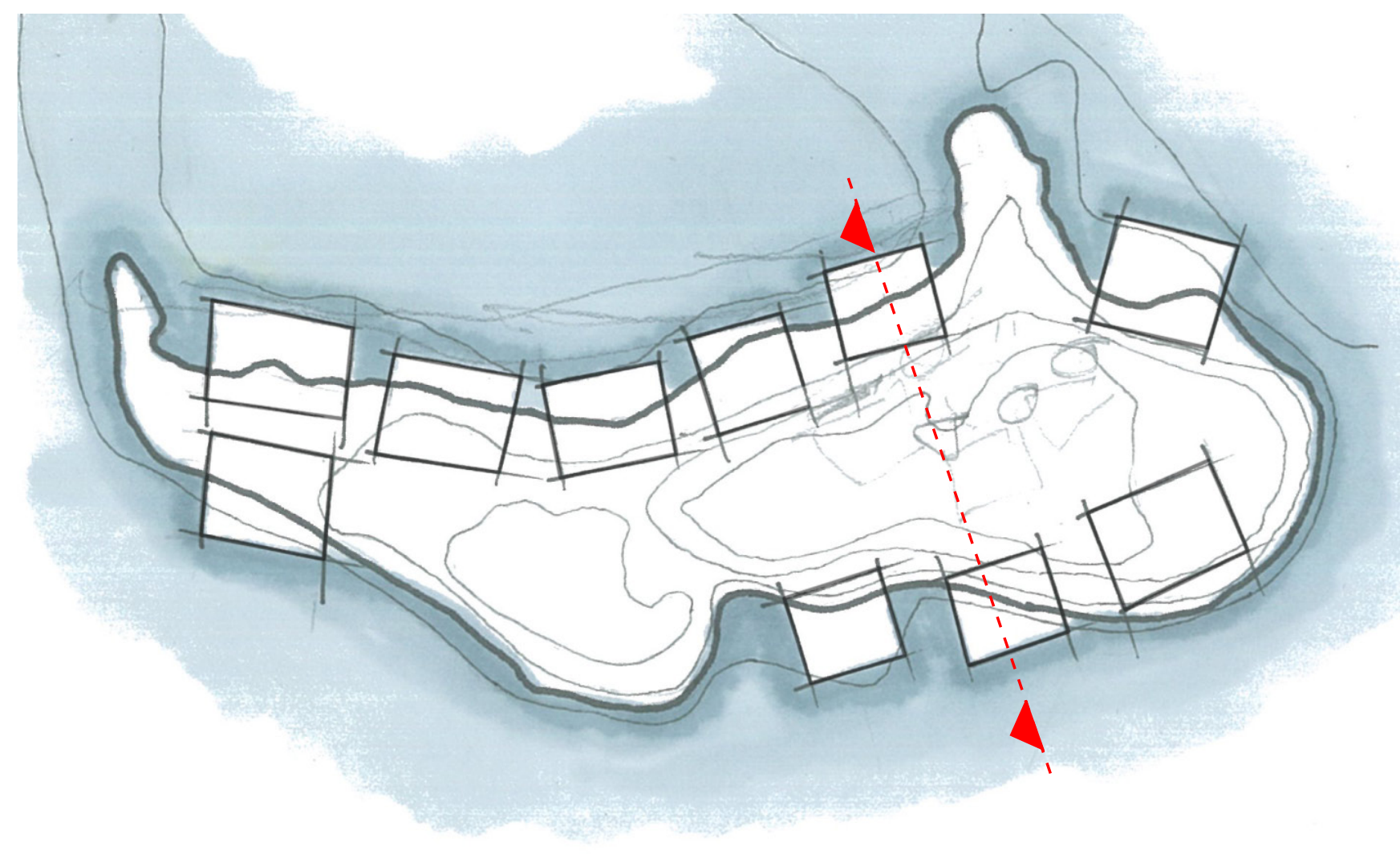

Fig 4.2 // Plan of first island design. A remaining land form after a $5 \mathrm{~m}$ sea level rise, With $2.5 \mathrm{~m}$ contours.
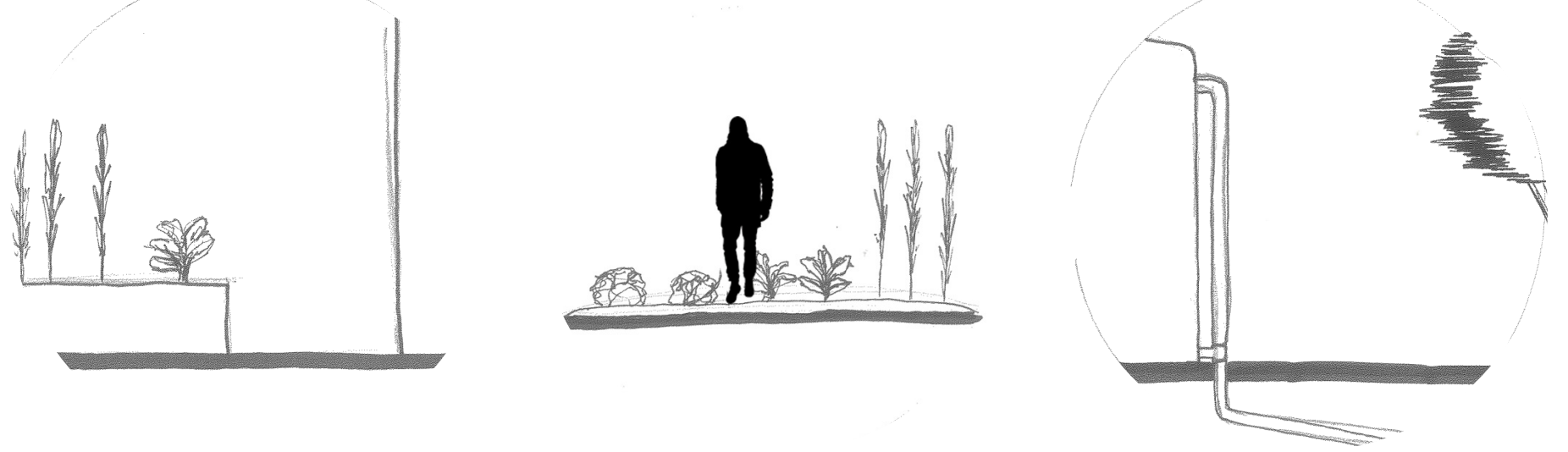

Fig 4.3 // Zooms of section on specific details of the islands functions, these specific detail the community gardens and rain water collection.

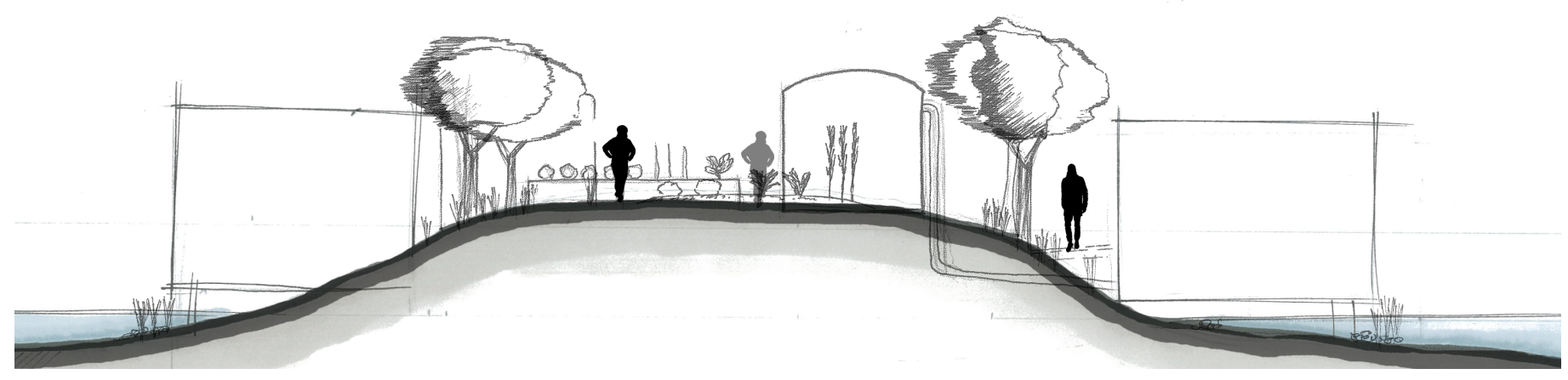

Fig 4.4 // Section of island design. 


\section{Bridges}

With that in mind, the designs needed to evolve so as to allow transport to and from each of the islands, allowing them to function as normally as they could without disruptions. Raising roads is currently used as a flood protection method. In this case, it would allow residents the ability to travel to and from the islands even with water levels rising. Water levels will fluctuate over time for flood events until one day when sea levels rise, houses could be strung across these bridge structures tying the islands together. Their backyards would seasonally flood and they would lose them for that time but for the rest of the time, it would be like normal. It would require the use of stilt housing and strong supports as water flows around the islands could become strong in larger floods, as well as objects floating down the river could collide with homes and potentially damage. 


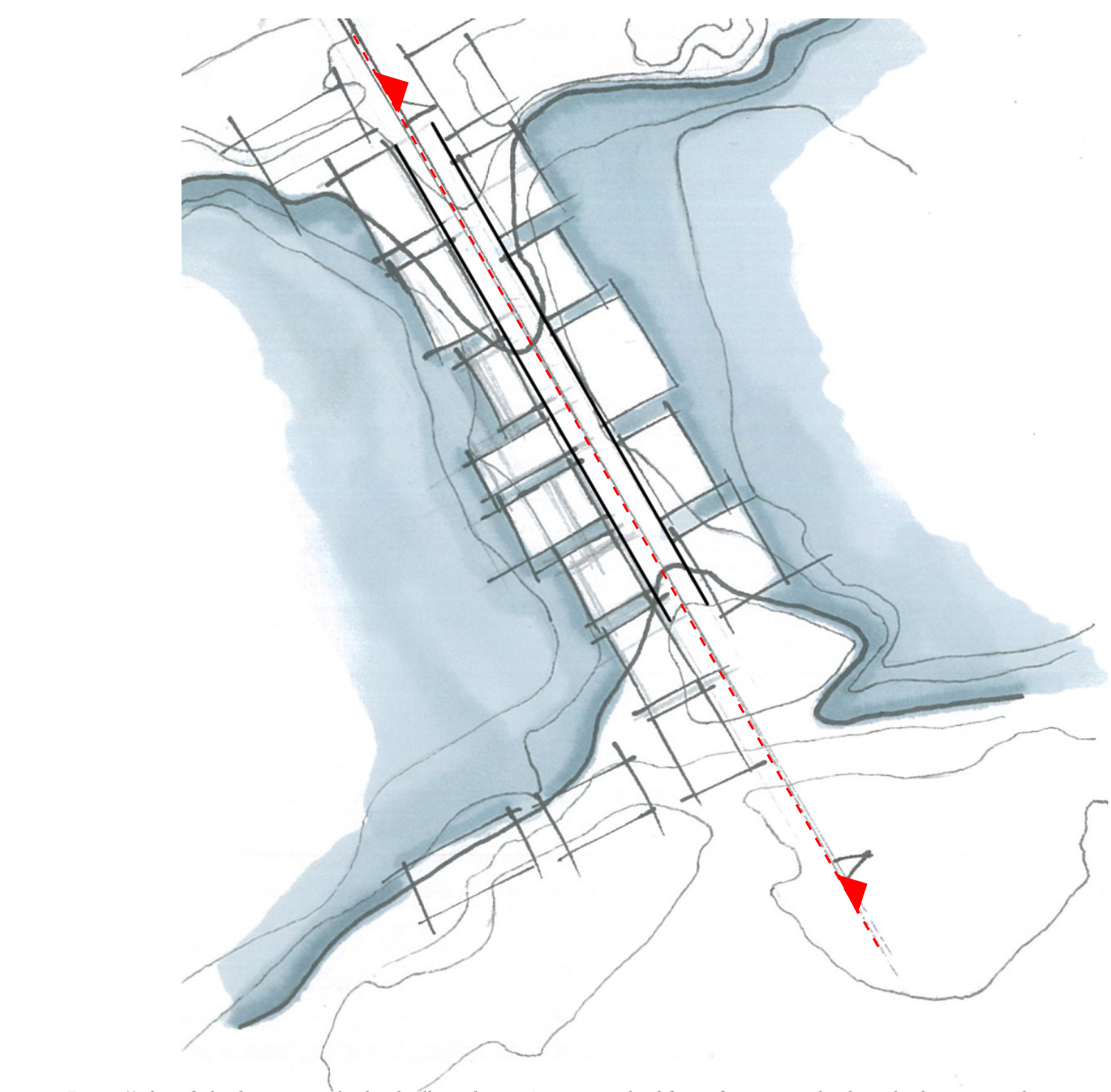

Fig 4.5 // Plan of island connecting bridge dwellings design. A remaining land form after a $5 \mathrm{~m}$ sea level rise, bridge spanning between two remaining islands. With $2.5 \mathrm{~m}$ contours. Not To Scale
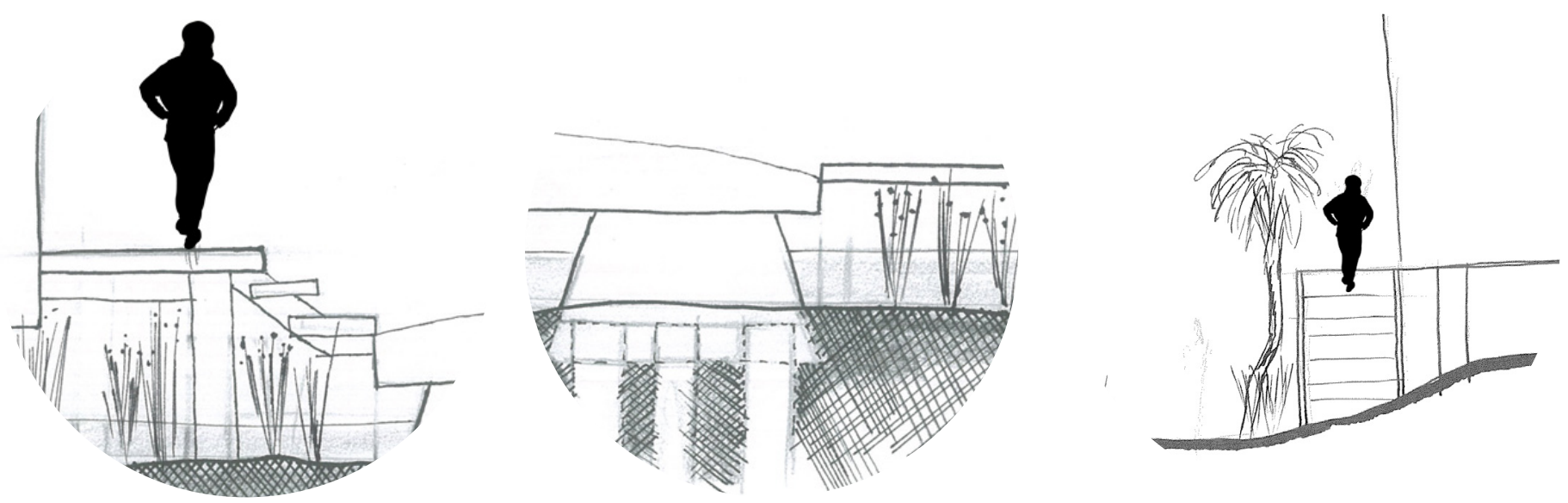

Fig 4.6 // Detail sections of design on specific details.

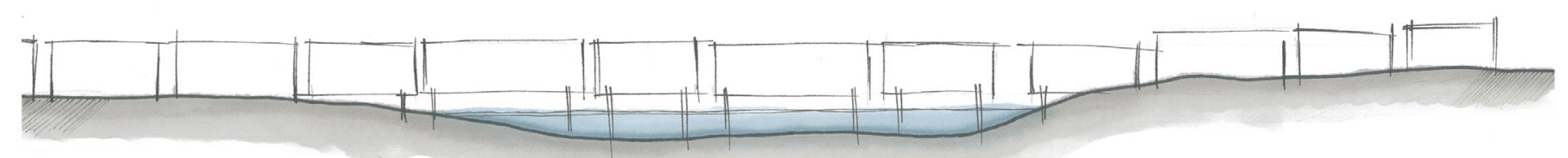

Fig 4.7 // Quick section of bridge housing design, aiming at showing relationship between water and the buildings. 


\section{The Cove}

The new formation of islands with access through their adjoining bridge networks would most likely function as small cul-de-sac communities. With the small size of each island and homes being packed together small tracks may join some residents to the main access routes of their island. Some areas may have their own private driveway but others may not have the room for that and will only have access via a pathway. Within the centre of a cluster of homes, there could be small private parks or open space that could be tailored to the resident's wishes, gardens, fields, gathering space for them all to congregate to, anything. 


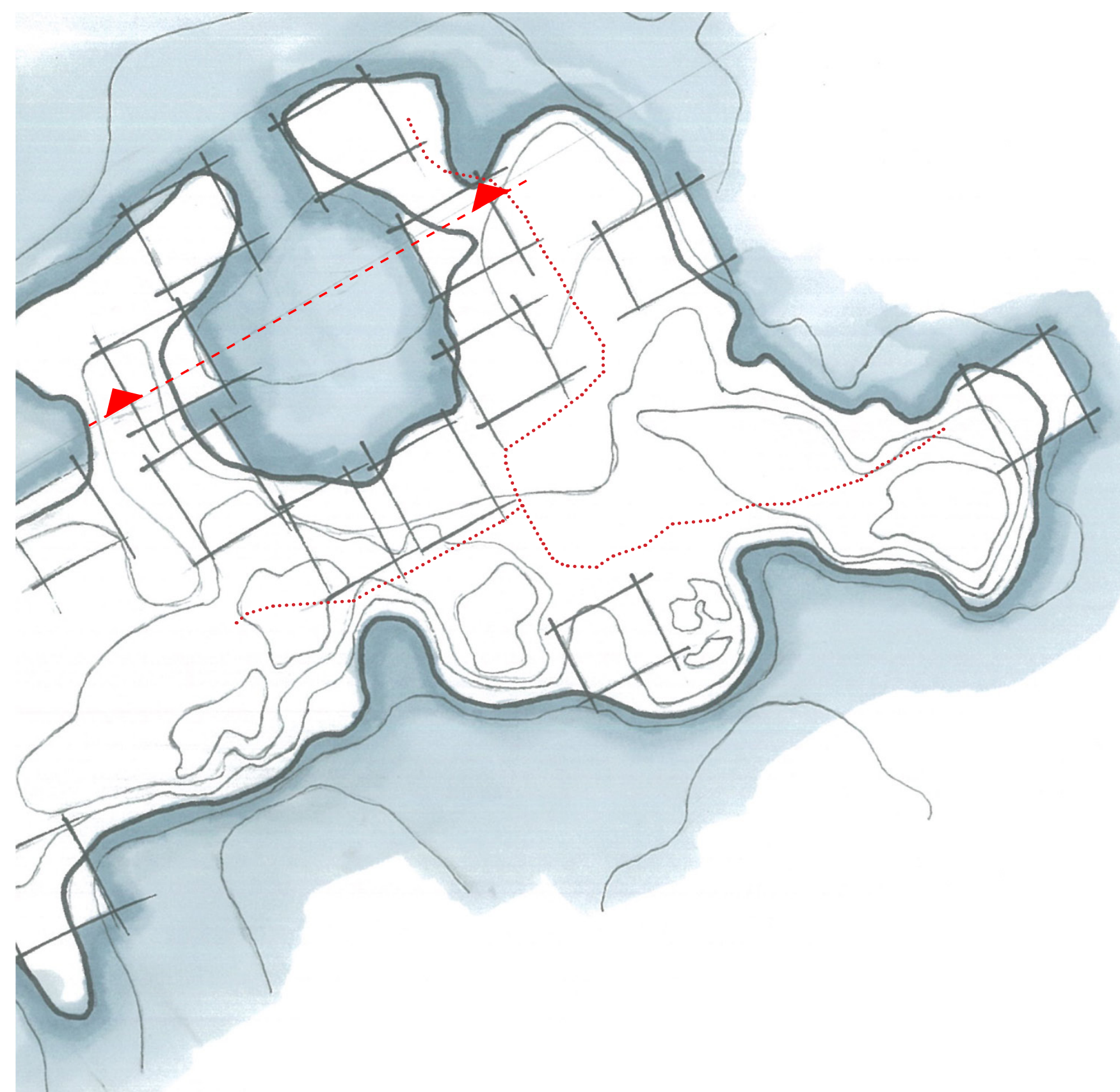

Fig 4.8 // Plan of cove island system. A remaining land form after a $5 \mathrm{~m}$ sea level rise, With $2.5 \mathrm{~m}$ contours. A protected cove creates an interesting interaction space between neighbours,

Not To Scale
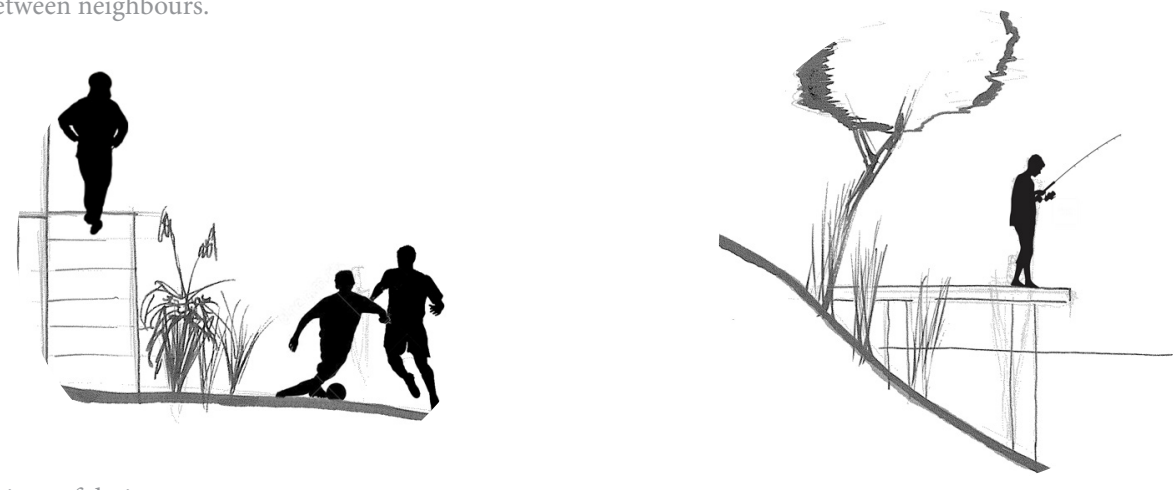

Fig 4.9 // Detail sections of design.

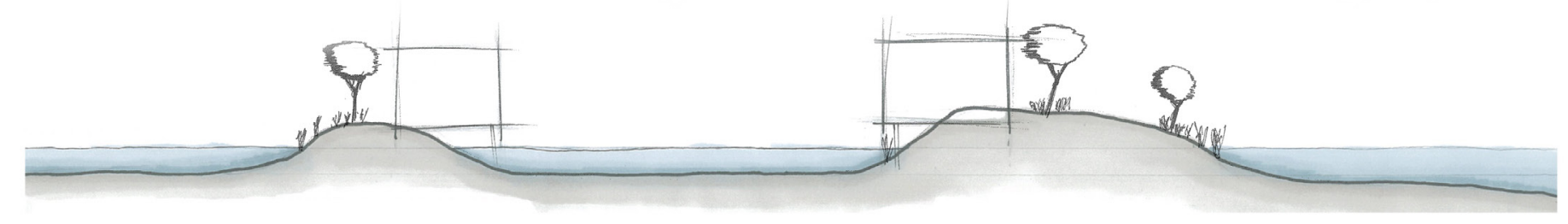

Fig 4.10 // Quick section of design aiming at showing the relationship of cove edges and the water. 


\section{Strips}

There is plenty of high point access on the site but what if we were to make more and increase the number of residences within this archipelago living situation. The location that this design was envisioned in is currently an overflow path near the village of Otaihanga. The river overflows into an area of farmland on the outskirts of the main part of the village, and flows around it out into the estuary. A series of undulating strips through the site would create high and low points, areas where people can live and when needed areas for water to flow through. The spaces between each of the strips would then become each properties backyard, which would flood when the river required to overflow through the site. 


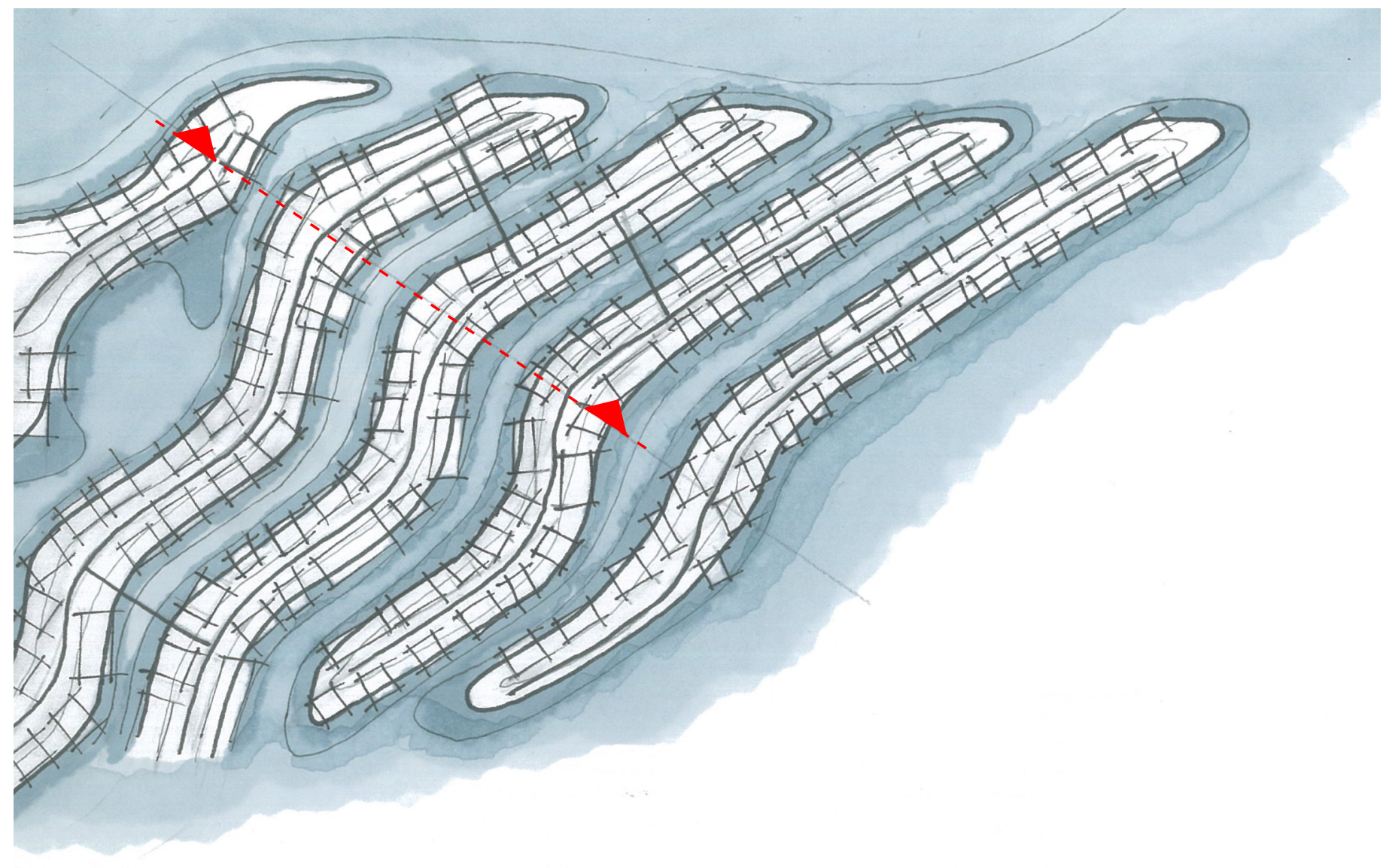

Fig 4.11 // Plan of Strip system. A constructed land form after a $5 \mathrm{~m}$ sea level rise, With $2.5 \mathrm{~m}$ contours. With the loss of most land due to the sea level rise, these bands of high ground are situated in the overflow path and still allow the water to flow through the overflow path.

Not To Scale
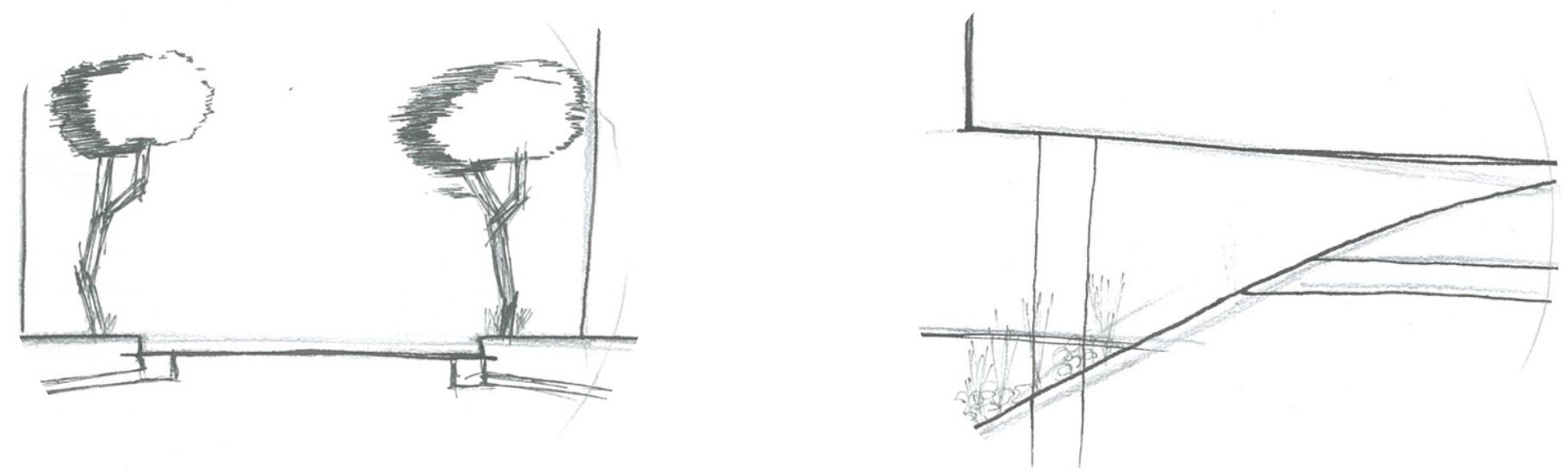

Fig 4.12 //Detail sections of design.

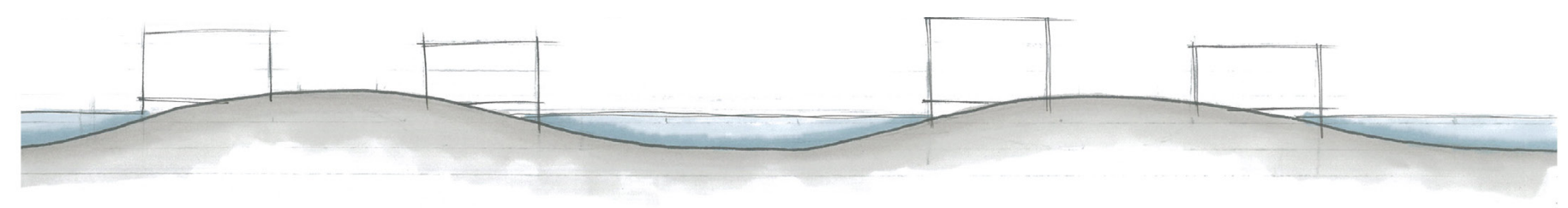

Fig 4.13 // Section of undulating strip design. High ground is for access and low points are backyards and overflow path. 


\section{Central Living}

Central areas of these islands could be built up and occupied by more residential abodes or they could become gathering points in emergencies if waters become too much. Public space that functions as parks, gardens, social space as well as functioning as emergency meeting points and safe spaces when waters become a bit too high or for other natural disasters. This particular design would work alongside the low high strip design, locations like these would be situated along the outside islands for residents from the strips to migrate to, not only during disasters but any time they would like. 


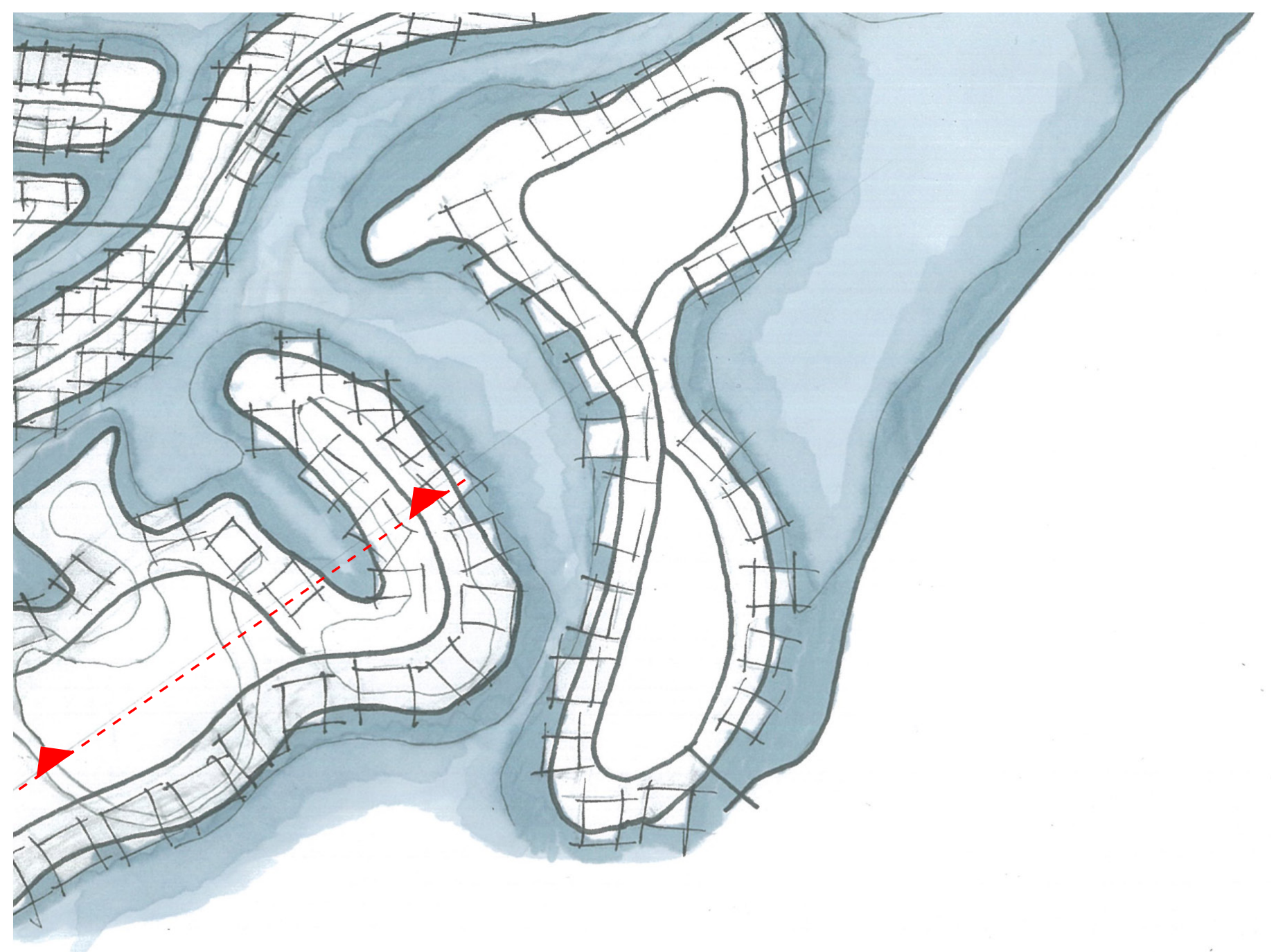

Fig 4.14 // Plan of adjoining islands to the Strip design. A remaining land form after a $5 \mathrm{~m}$ sea level rise, With 2.5m contours. Built up strips can be seen in the top corner.

Not To Scale
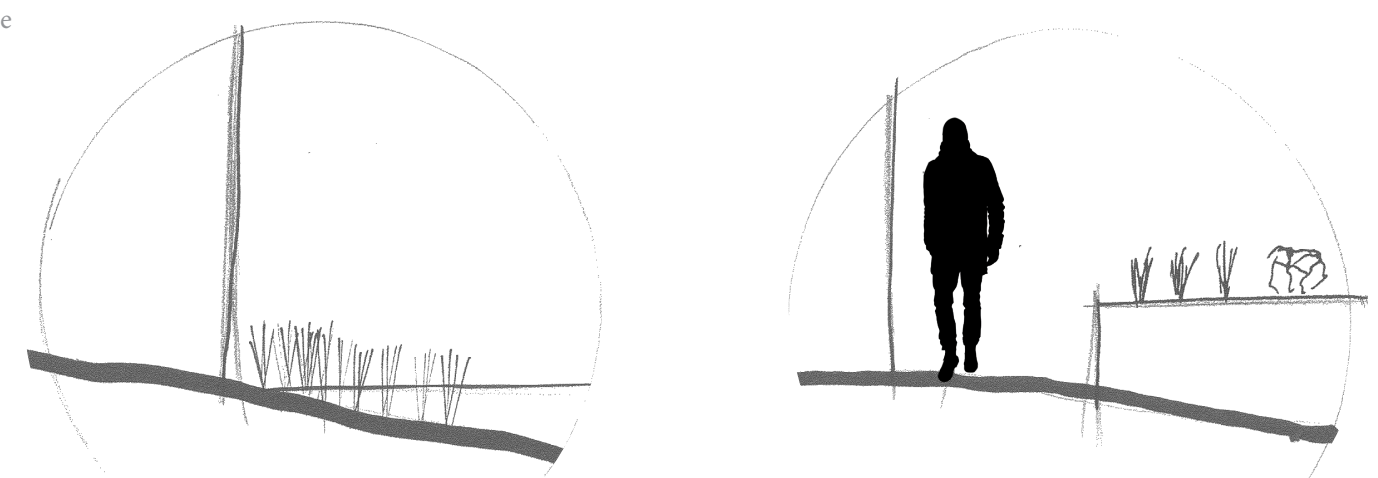

Fig 4.15 // Detail sections of design.

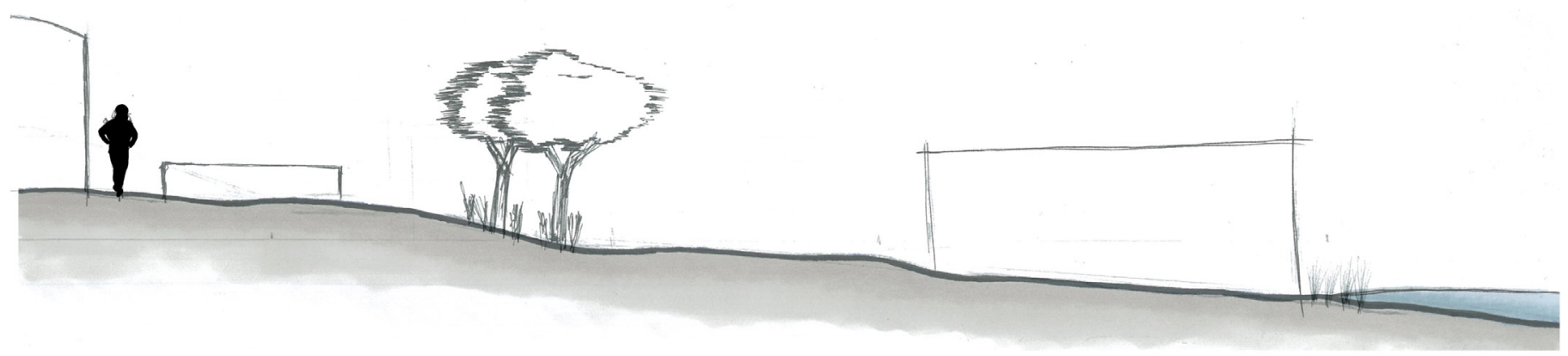

Fig 4.16 // Section of the relationship between water and community area. 


\section{Intensified}

The final exploration in this initial series aims at providing for the potential increased population of Kapiti in a densified community. If sea levels rose, if floods became more regular and only certain locations were suitable for building, usable land would become less and density would have to occur. Large clusters of building, would surround a central space creating a wall against the elements, these central spaces would function as shared backyards for all residents in each cluster across the site. 


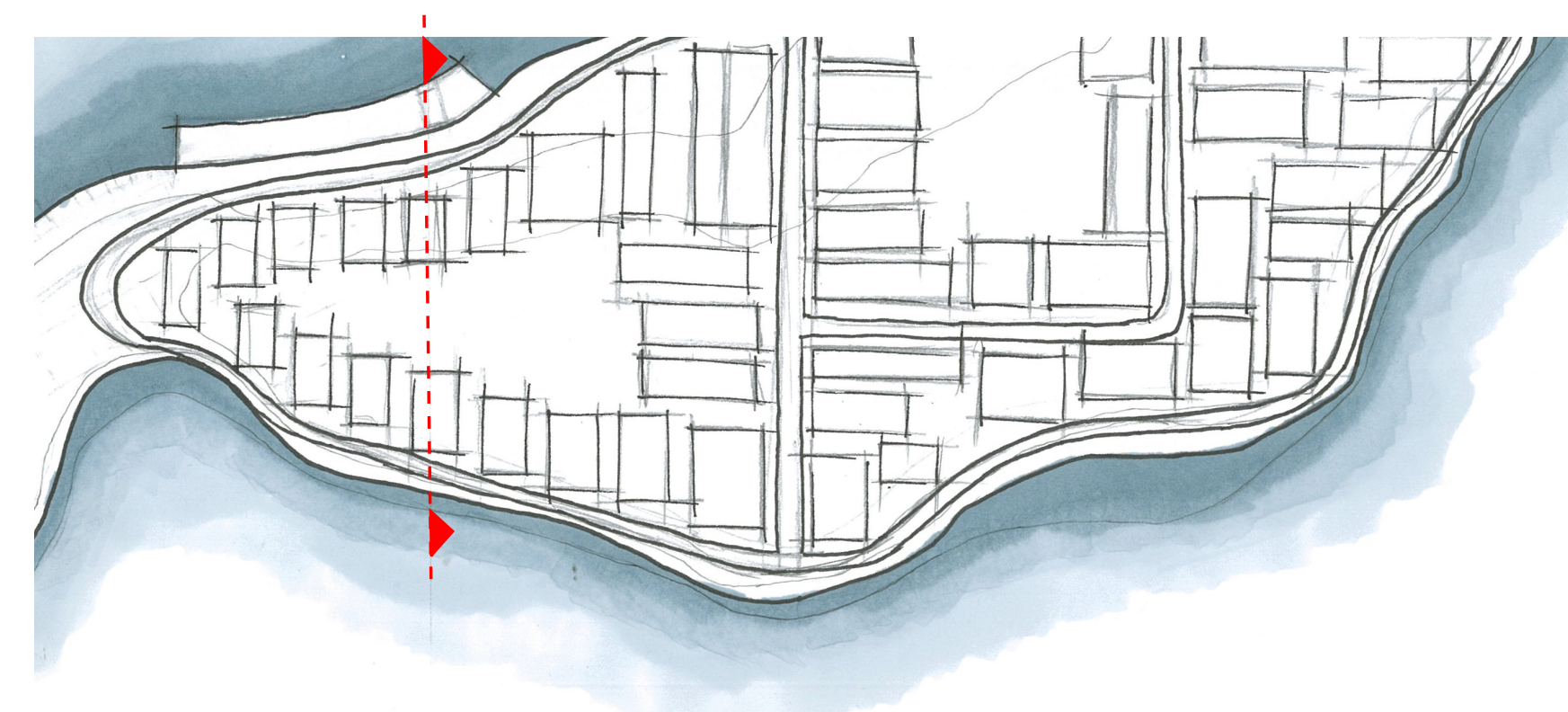

Fig 4.17 // Plan of built up design. A remaining land form after a $5 \mathrm{~m}$ sea level rise, With $2.5 \mathrm{~m}$ contours. A much more compact design, less land to build but with the same amount of people will mean living on top of each other.
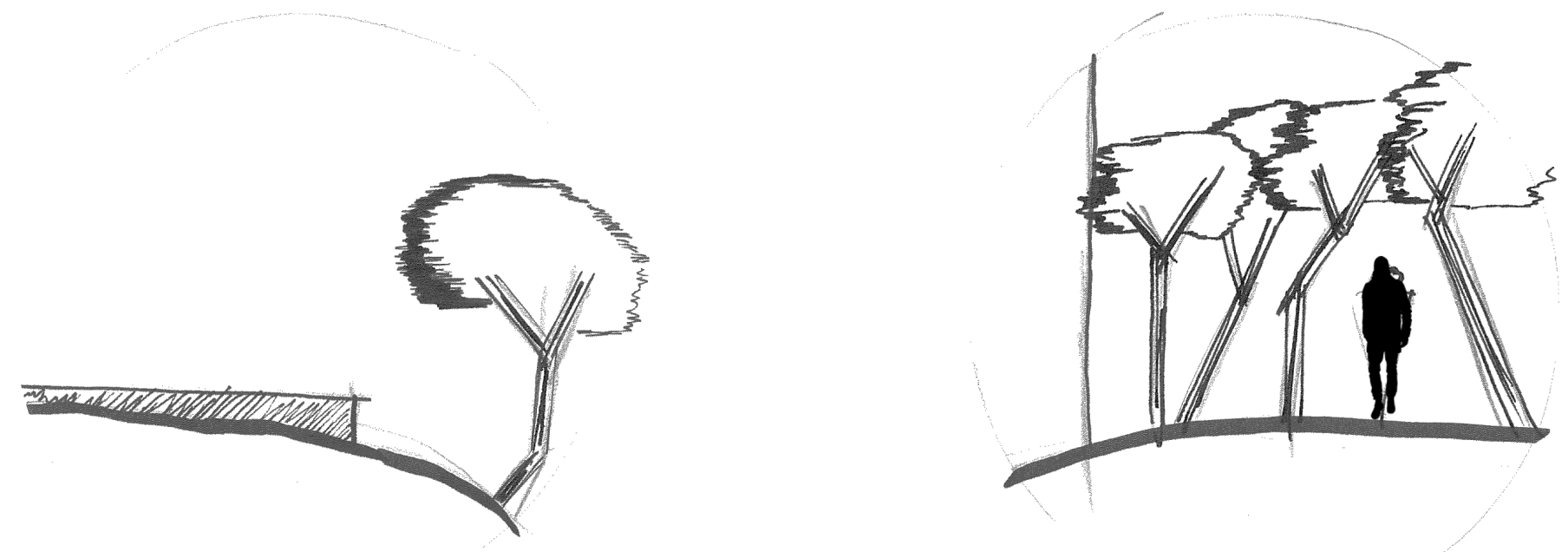

Fig 4.18 // Detail sections of design.

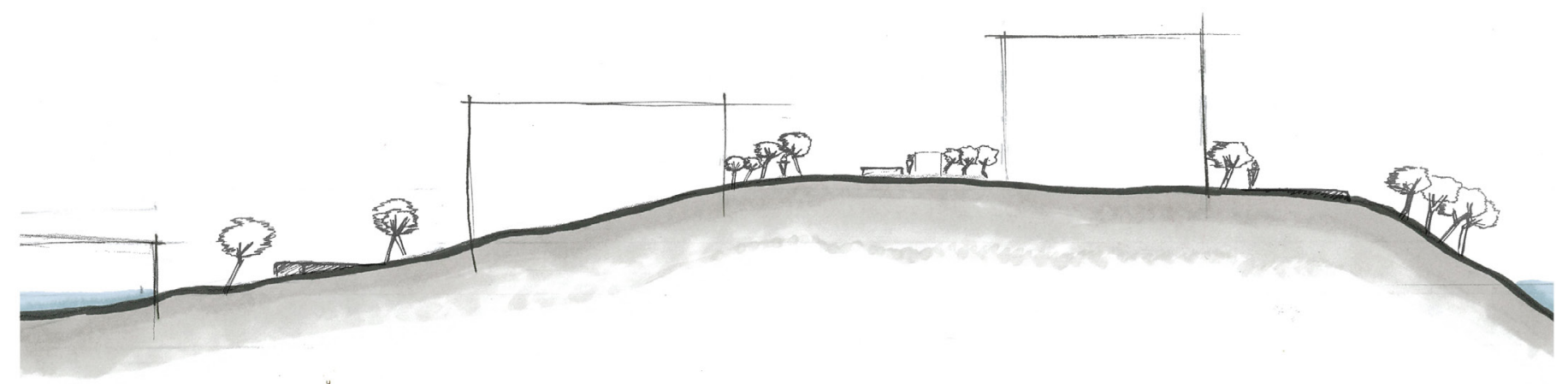

Fig 4.19 // Section across design. Scale of buildings can be seen from the relationship next to the trees. 


\section{Discussion}

A few conclusions were made from this set of explorations. One was the drastic change that the site would have to go through to get to this point and the large time scale that it would be looking at. An event like this could take anywhere from 10 to maybe 100 years to form which does leave a lot of time to prepare for it to happen. But what is really being asked is how do we solve the problem that is happening now and not so far into the future? Although some of the ideas working within these initial concepts could be used later not making this work a loss.

The social implications of these designs came to mind as well. Looking back at the design, how would this style of living be perceived to those who don't live there? Each community would essentially become their own private island, as access is lost due to rising waters. Car travel would be lost directly to your home and boats would have to become the predominant mode of transport. This is probably not possible to the average New Zealand family, thus this may attract only a certain class of people.

These initial designs failed to achieve what was being asked of the research thesis. With the new expressway going through the Kapiti Coast and the potential for Wellington, as a region, to expand because of it, we need more room in the future and these designs removed a whole lot of it, allowing the water to move in and push us back. At the beginning of these designs, the question was "How can we settle on floodplain areas?", Which we already do, as most of the Waikanae catchment is a floodplain and these initial designs don't really answer that. So maybe it is the wrong question to be asking.

A step back needed to be taken, and a review of what was being asked by the question. The issues were still flooding and the settlements that are affected by it, but there must be more to it. Methods of flood protection needed to be investigated and something more than just flooding and settlement. What else was going on in the site? 

8 ,
FURTHER
ANALYSIS

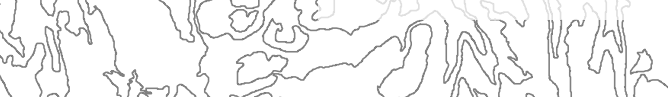
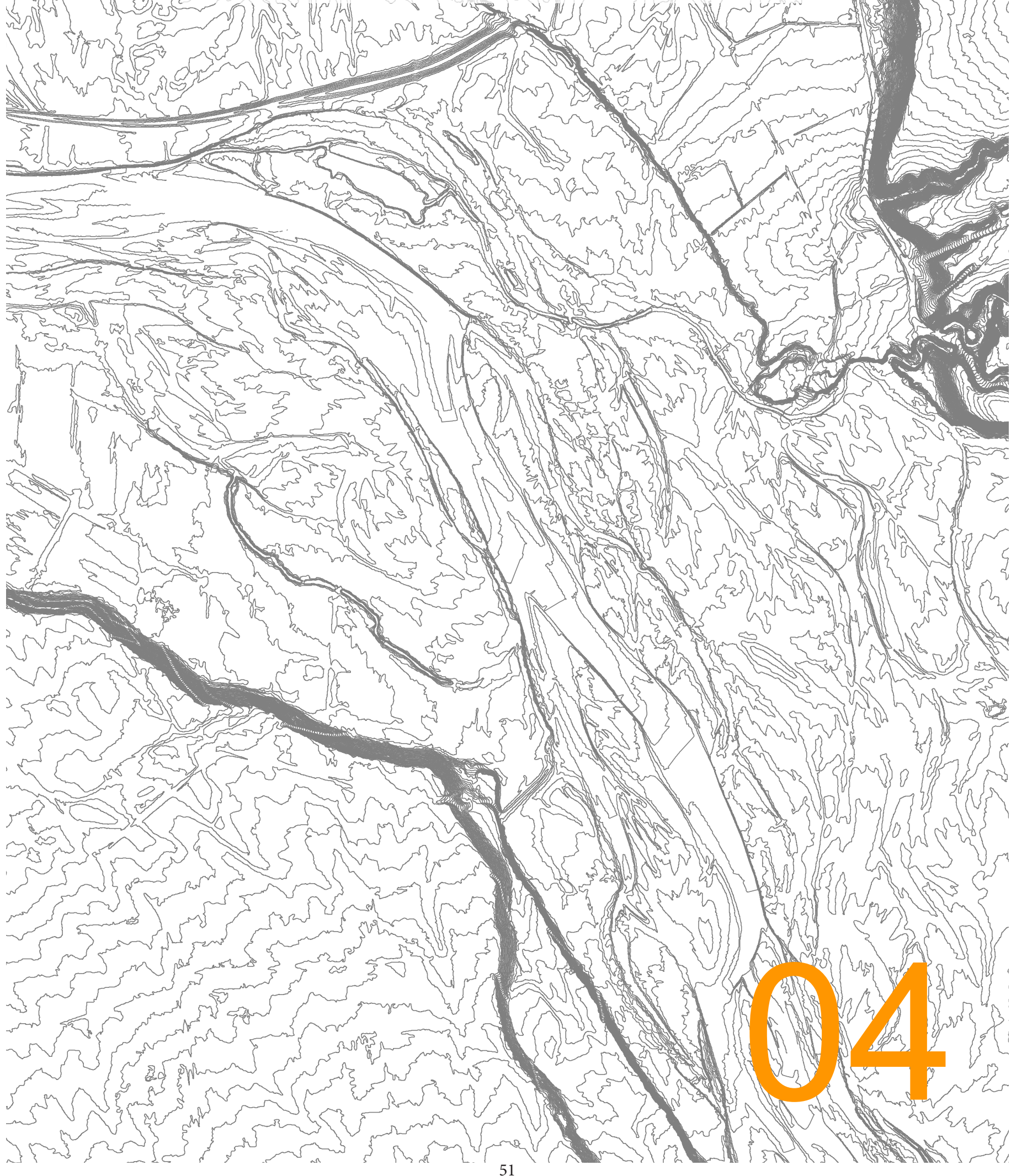


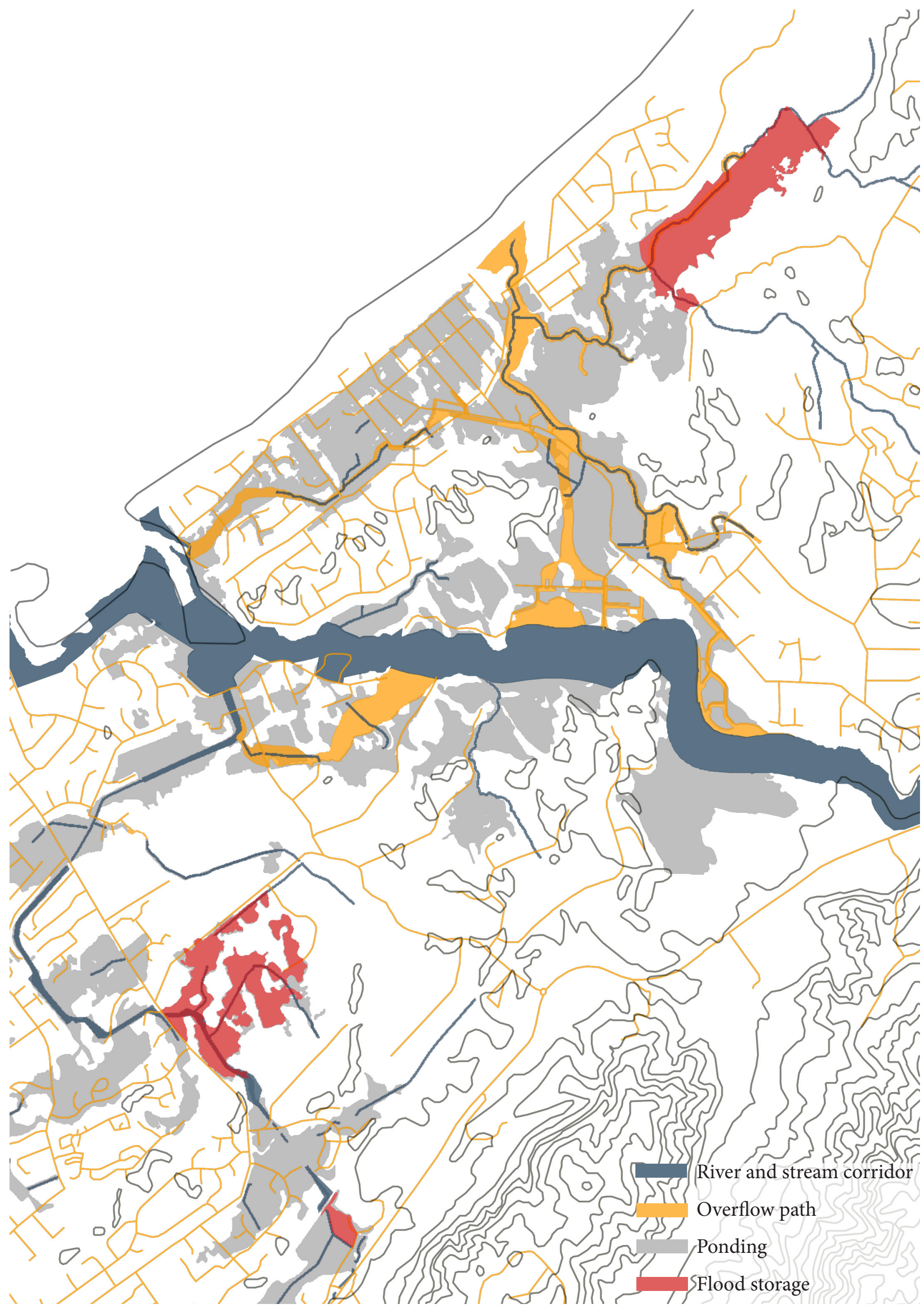

Fig 5.1 // Flooding conditions of the Waikanae River. Flood storage is nowhere near the river so has little help there. 


\section{Flooding}

Flooding is a natural occurrence of a river system. Flood hazard is the result of human modification of this sensitive river system through the removal of its natural features and addition of some forms of flood control. The Waikanae River has undergone some big changes over time. All rivers change over time as they meander across the floodplain but these are natural changes that a river goes through. It is only when humans start to intervene with the rivers course that problems occur. Before man intervened, the Waikanae River meandered across the catchment leaving scars where it has once been. When the land began to be settled areas along the river were drained and turned into farmland and slowly pushed the river into what it is today, post 1955, flood protection methods were implemented along the course of the river to hold back the water the next time it happened, but unfortunately it only moved the problem when it happened again.

While looking at how the Waikanae River functioned, two documents were reviewed, the Waikanae Floodplain Management Plan, and from that, the Waikanae River Environmental Strategy. Both these documents were created to aid in the efforts to protect and improve the Waikanae River, providing an agreed vision to work towards and setting out a range of recommended actions to enhance the river. In the first section the Waikanae River Environmental Strategy gives some background the updated strategy, saying that the river is of tremendous value and importance but it also refers to it as a special ecological corridor providing a "mountains to sea" ecological corridor from the Tararua Ranges to the Waikanae Estuary Scientific Reserve and then on to the Kapiti Marine Reserve and the Kapiti Island Nature Reserve. 


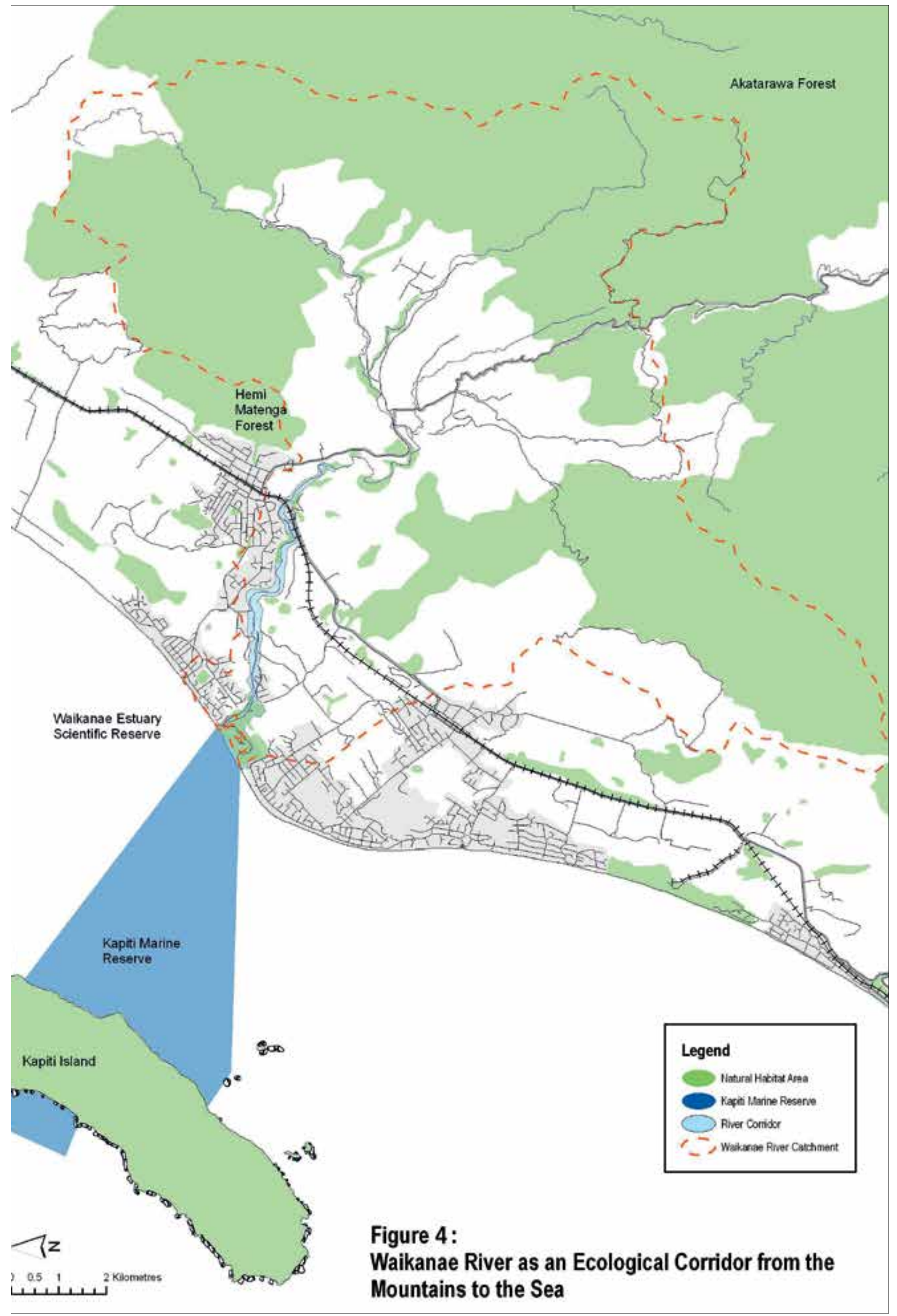




\section{An Ecological Corridor}

An ecological corridor provides for the native species the ability to move between habitats as well as creating genetic diversity amongst their populations. There is a large potential list of birds, fish and reptiles that live on the Kapiti Coast. With Kapiti Island being a predator free bird sanctuary, many of the species in Fig 5.4 can be seen across Kapiti, as well many migratory species use the Waikanae Estuary as a stop on their travels. Many of these bird species long ago would have called the banks of the Waikanae River home, but over time this ecological corridor has changed and no longer functions as well as it once did, and it may never again.

The indigenous vegetation along the river was once a patchwork of native plants. Inland where it is drier the vegetation would have consisted of Kohekohe and Tawa trees. Closer to the coast where it was wetter, wetlands and swamp forests were both areas that had the potential to contain many of the species in Fig 5.4 creating a very diverse ecosystem. This was all cleared to make way for farmland once the settlers arrived.

River vegetation or the riparian zone, is the strip of vegetation along the river bank that helps to dissipate river energy slowing water flow in flood events, reducing erosion of the river bank by binding the soil with its root system and minimising the damage that floods do. Riparian zones have both social and ecological values that add to the areas around them. Socially they contribute to the surrounding property with great views and amenities. Ecologically they provide habitat for the wildlife of the region and bind the ecological corridors. 


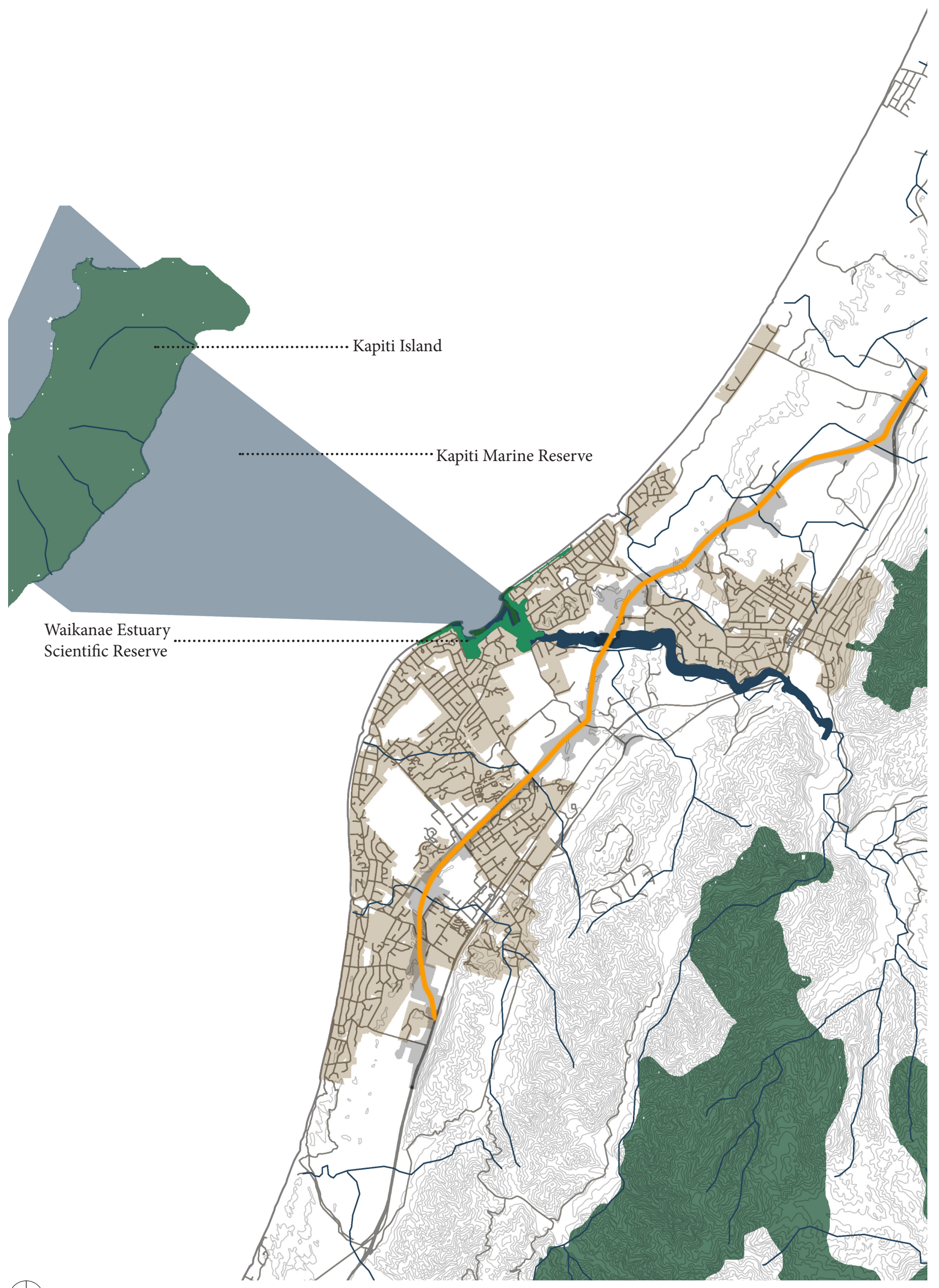




\section{Ecological Corridor}

Taking a look at the Waikanae River's ecological corridor provided from the Waikanae River Environmental Strategy Fig 5.2 it's hard to understand whether there is an established corridor or not, due to the quality of the image. To figure this out a new map was created to better understand it and see how urban sprawl may be affecting it. As can be seen in Fig 5.3, Kapiti Island and the Waikanae Estuary are connected via the Kapiti Marine Reserve but the Tararuas sit relatively disconnected from the rest, separated by Waikanae township and large amounts of farmland. Settlement along the Waikanae River has taken over the river edge and removed the river edge ecology.

A new opportunity arises. With the lack of natural river edge ecology along the Waikanae River, a chance to replace this could benefit the river and increase the value of the river to local communities, as well as perhaps aid in the protection of them. But we have passed the point at which just this will help to defend settlement, with floods seeming to be getting bigger and bigger every time, there may be a point where nature can no longer be resilient enough to aid us. 


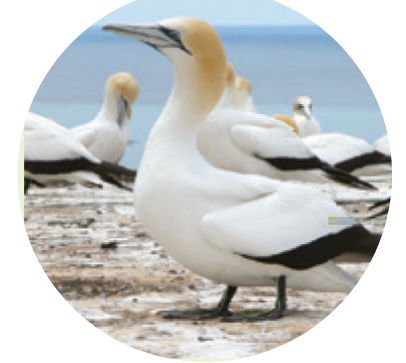

Australasian gannet/tākapu

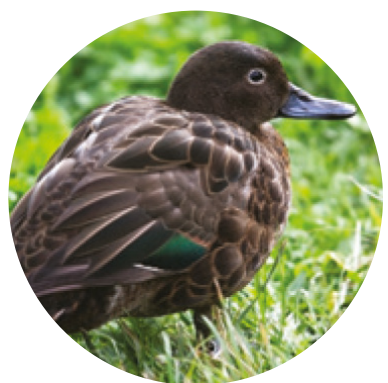

Brown teal/pāteke

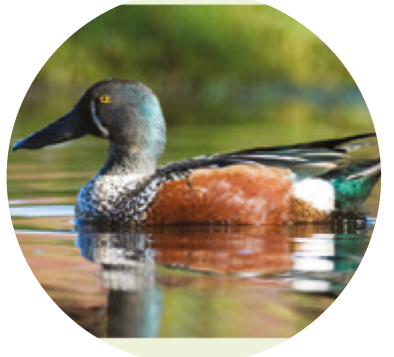

Australasian shoveler/ kuruwhengi

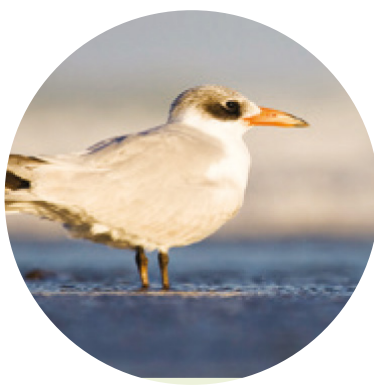

Caspian tern/tara nui

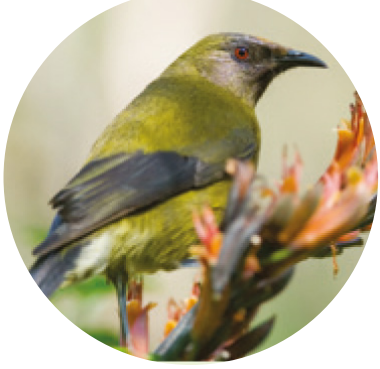

Bellbird/korimako

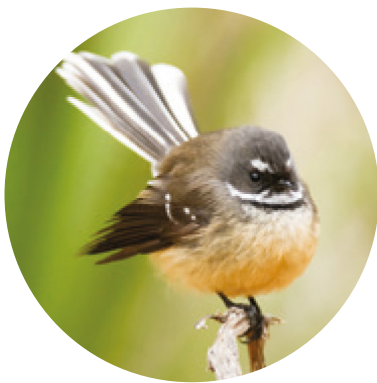

Fantail/pīwakawaka

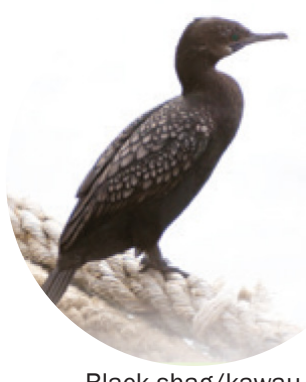

Black shag/kawau
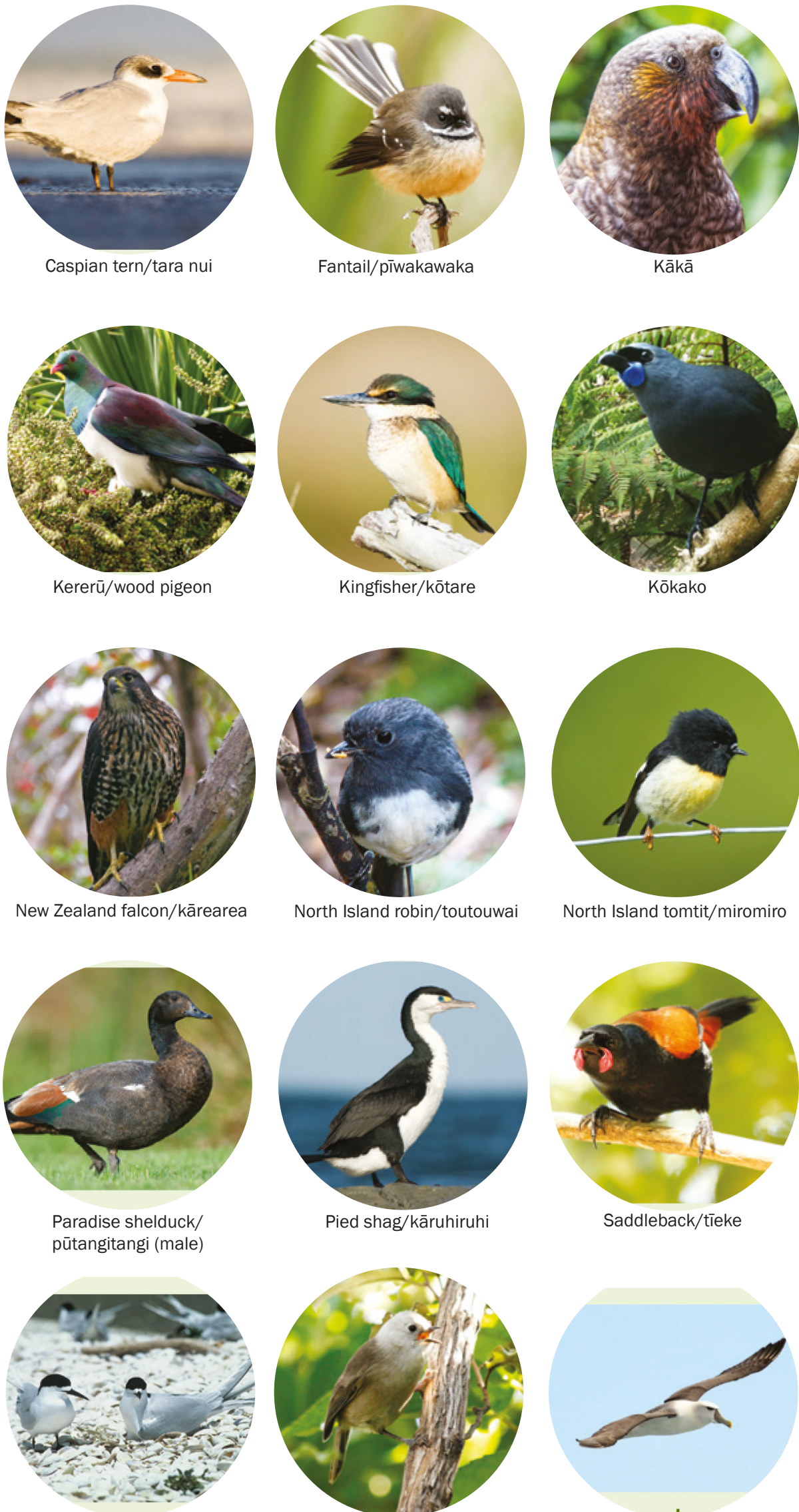

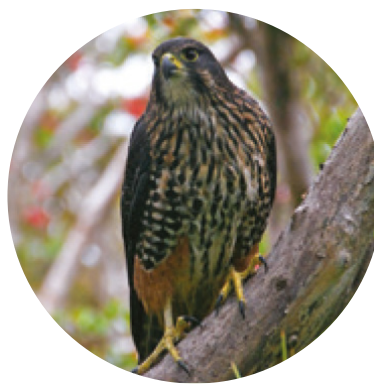

New Zealand falcon/kārearea

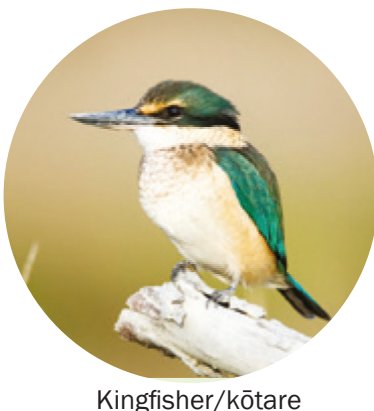

Kingfisher/kōtare

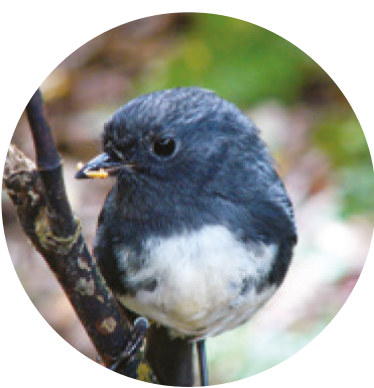

North Island robin/toutouwai

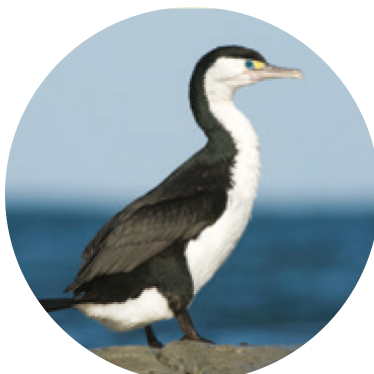

Pied shag/kāruhiruhi
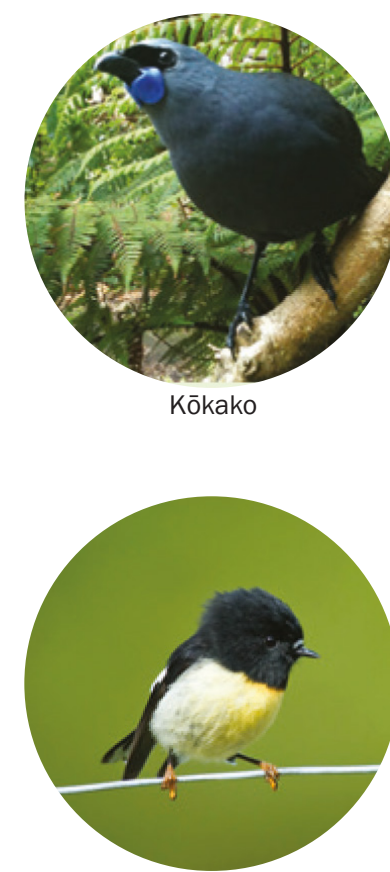

North Island tomtit/miromiro

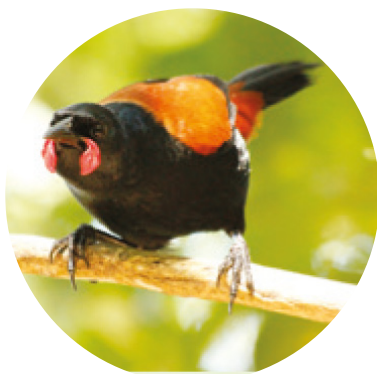

Saddleback/tīeke
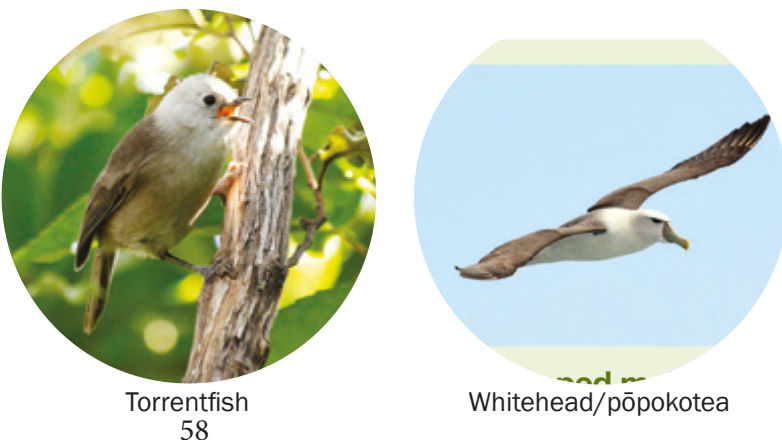

Paradise shelduck/ pūtangitangi (male)

White-fronted tern/tara

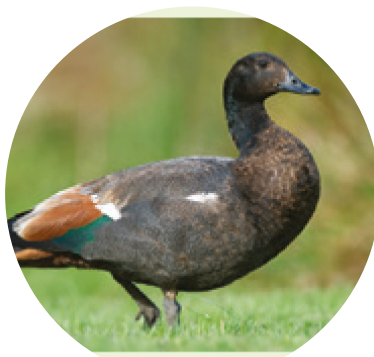

Paradise shelduck/ pūtangitangi (female

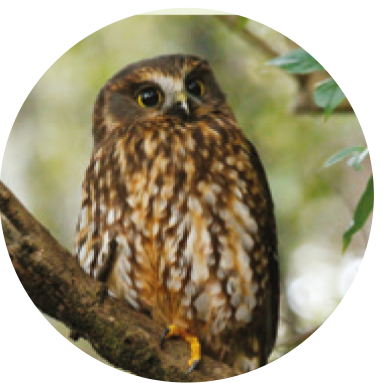

Ruru/morepork
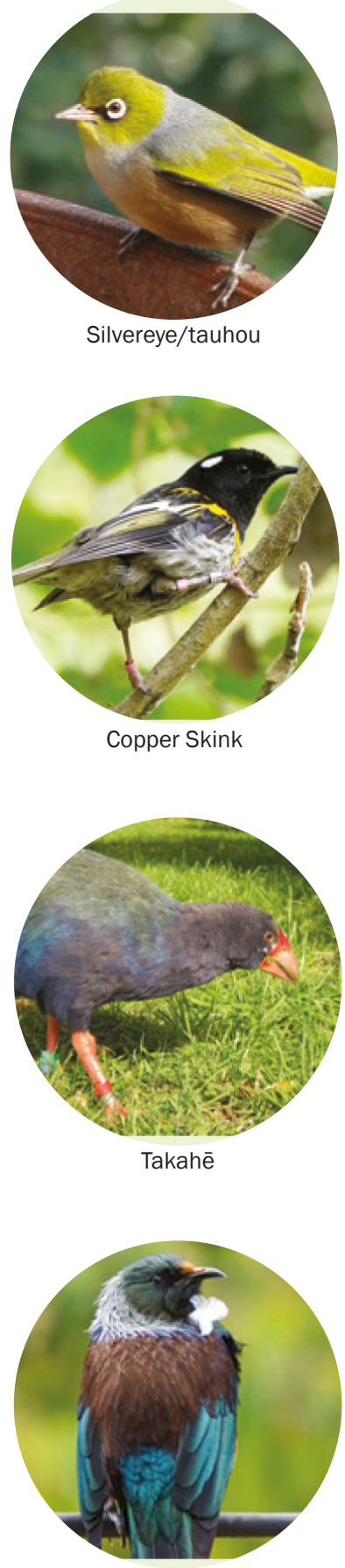

Tūī

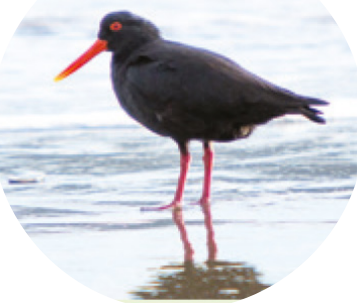

Variable oystercatcher/tōrea pango

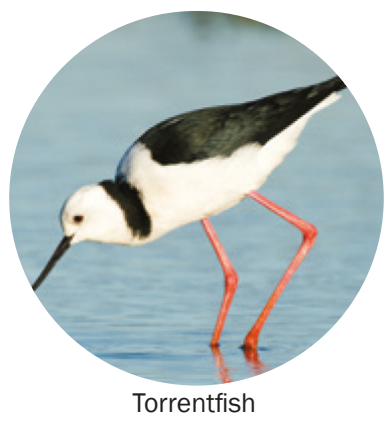




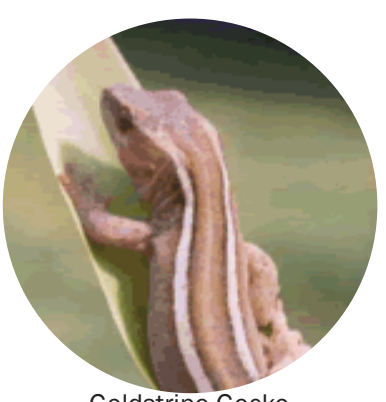

Goldstripe Gecko

Woodworthia chrysosireticus
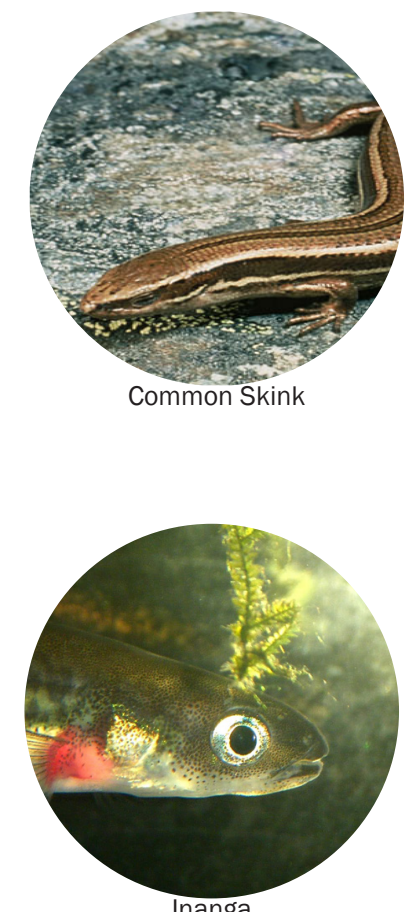

Inanga
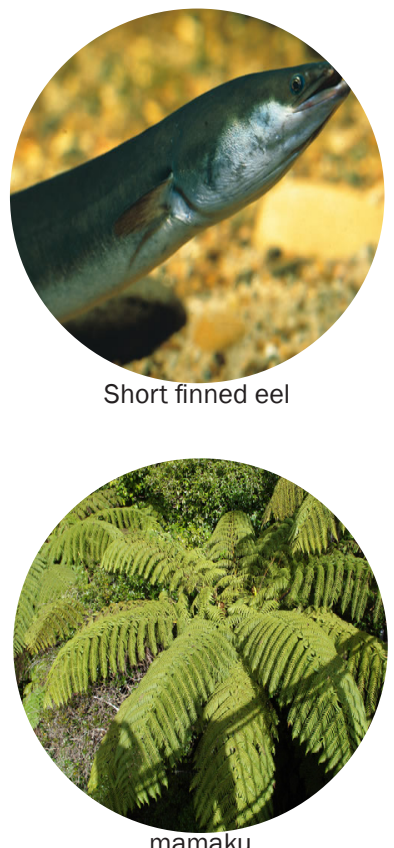

Cyathea medullaris

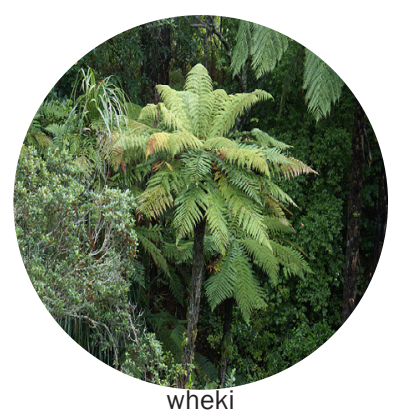

Dicksonia squarrosa

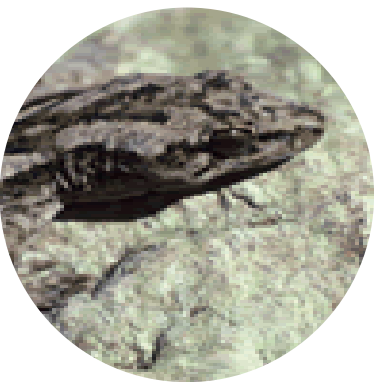

Common Gecko

Woodworthia maculatus
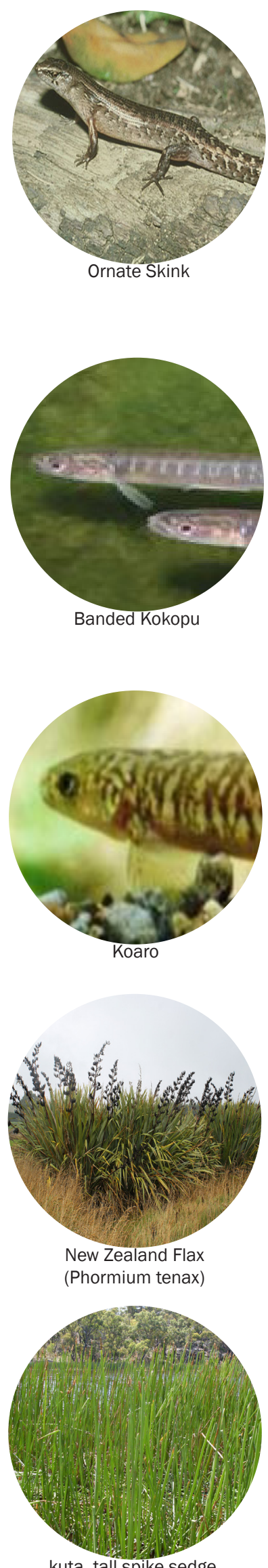

kuta, tall spike sedge, Eleocharis sphacelata

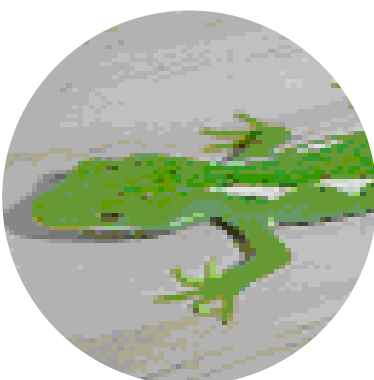

Wellington Green Gecko Naultinus elegans punctatus

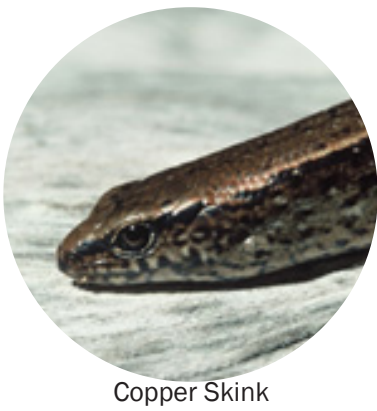

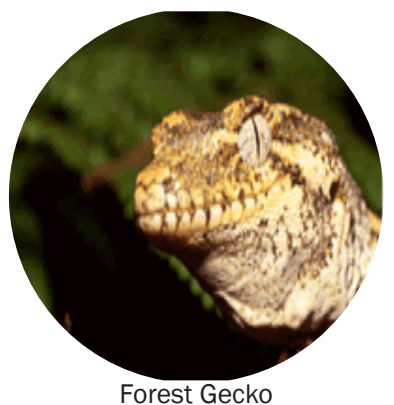

Mokopirirakau granulatus

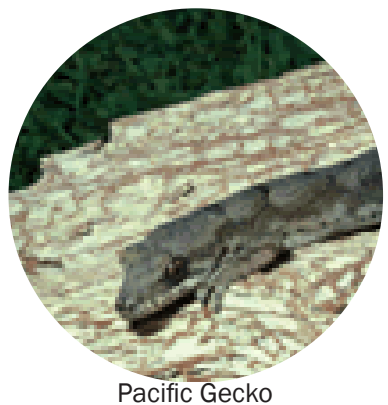

Dactylocnemis pacificus
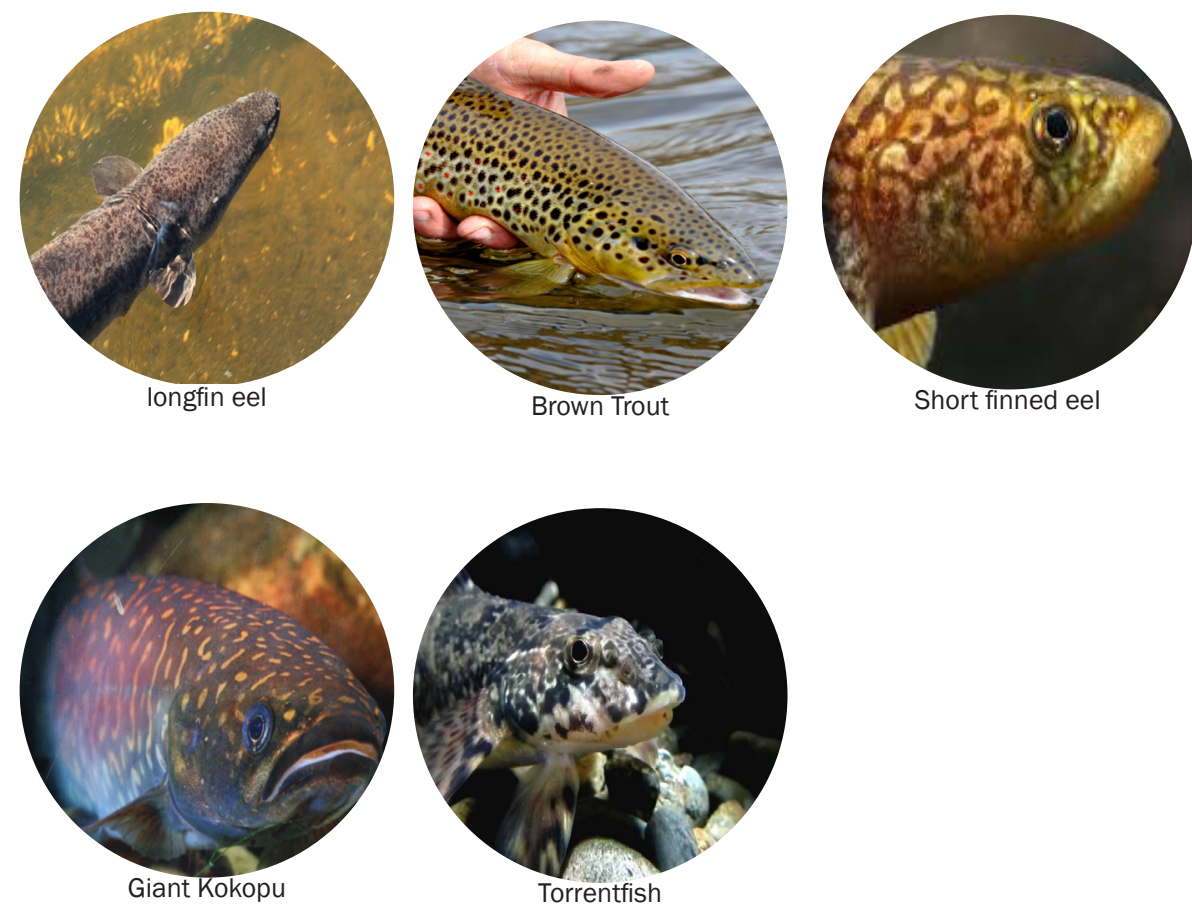

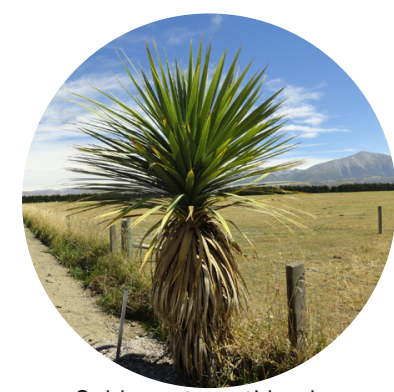

Cabbage tree, ti kouka, Cordyline australis

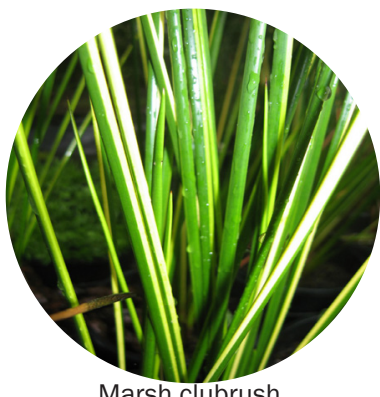

Bolboschø̄enus fluviatilis
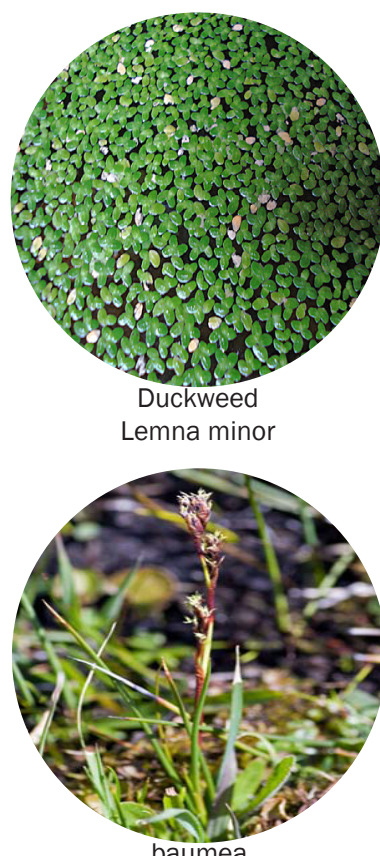

Baumea rubiginosa

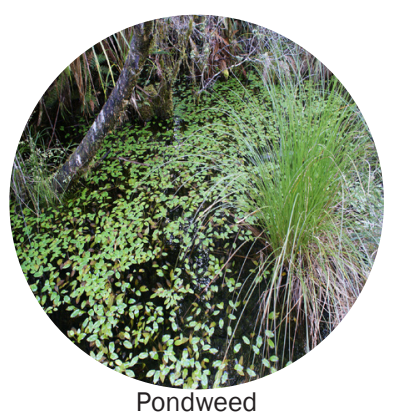

Potamogeton cheesemanii 


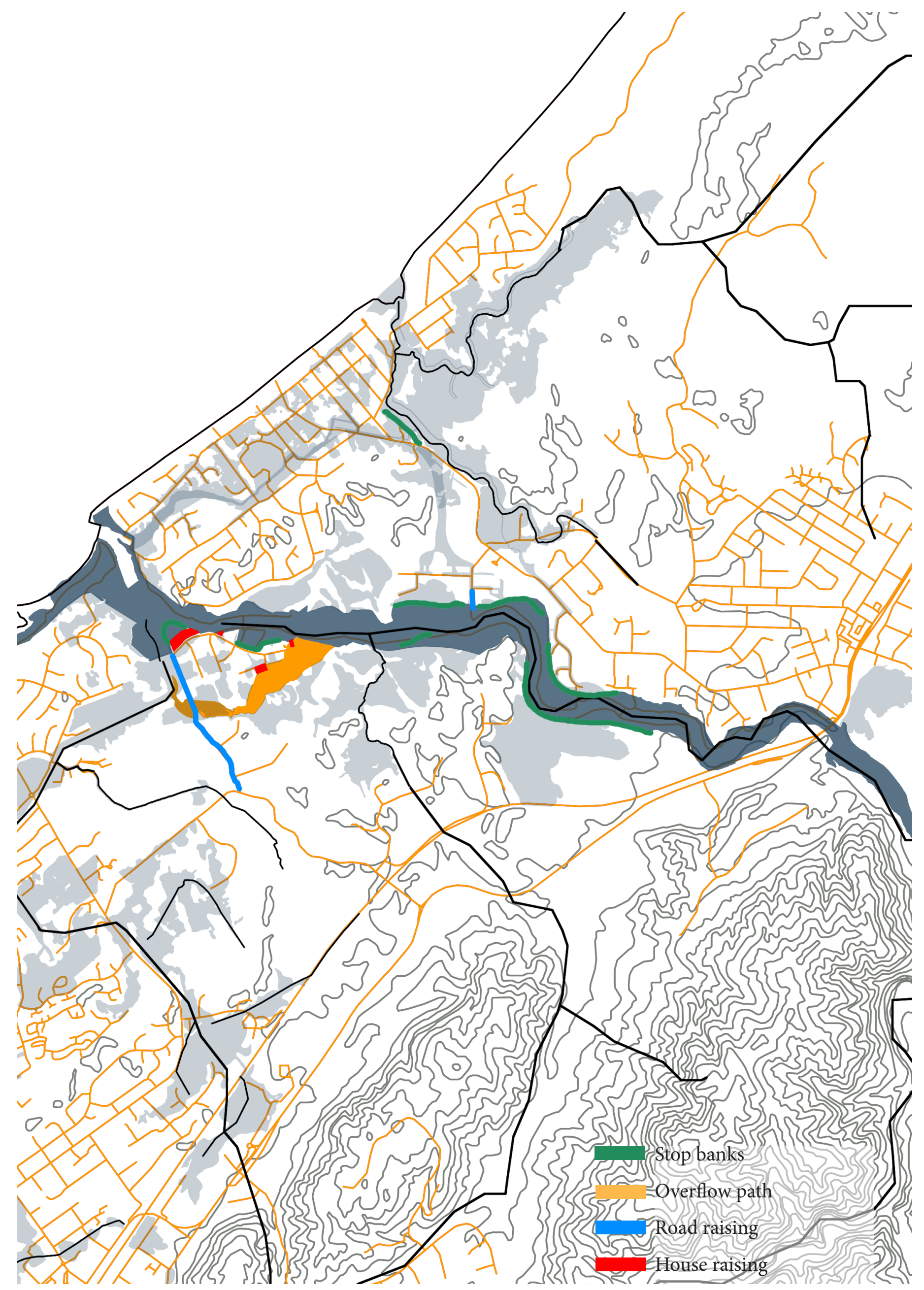

Fig 5.5 // Current Flood Protection Methods, Waikanae River. Stop banks in green can be seen to be patchy along the river. 


\section{Flood Protection/ Flood Control Methods}

Flood control is not a man made thing. Nature has its own ways of dealing with flood events, and man has had only a fraction of the time that nature has had to attempt the same. Humans have put in place many systems to try and control floods. From dams, diversion canals, stop banks, the list can go on. Along the Waikanae River stop banks are the main defence against flooding, along with some road and house raising in some of the worse areas. Although earlier implementation of stop banks along the Waikanae River has not seen much success, as seen after the 1985 flood, where the flood waters were just moved along the river.

Nature has had a lot longer to work on this issue, so why haven't we taken a leaf out of its book? Vegetation is a great defence, trees and bushes catch rainfall before it hits the ground. Their root systems absorb the water out of the soil, but in an article from Newcastle University Environmental Agency, they say that for there to be a real difference, large areas need to be reforested. This in combination with other smaller interventions, such as water storage areas, tree dams along smaller streams that connect with the river, and structures to slow the water down rather than flush it out to the ocean, has a chance to help reduce flood hazards.

Early human interventions are designed to move the water along and get it away from populated spaces. But really the best option is to slow the water down, reducing the impact it will have downstream and the damage it will cause. For the case at Otaihanga, there is no more downstream. It sits at the mouth of the Waikanae River so a combination of more upstream interventions as well as allowing the water to travel outwards from the river during floods will be needed. This is potentially possible. In the diagram across the area in orange is an overflow path, an area that in floods, the river already wants to travel across. Currently, this is private farm land, but once it may have been a path that the river took before humans tried to tame it. This path flows around Otaihanga and out into a stream which then flows to the Waikanae Estuary. Perhaps this could be a starting point to then work up and slowly change it for the better, allowing the river to evolve to the issue at hand. 


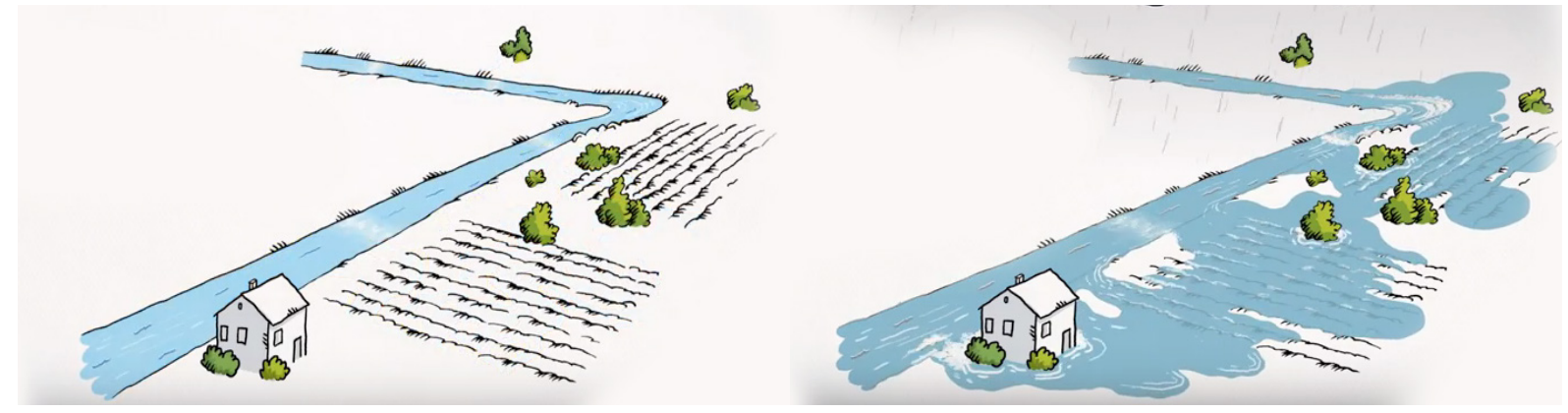

Fig 5.6 // Modified rivers accelerate flow and cause more damage downstream.
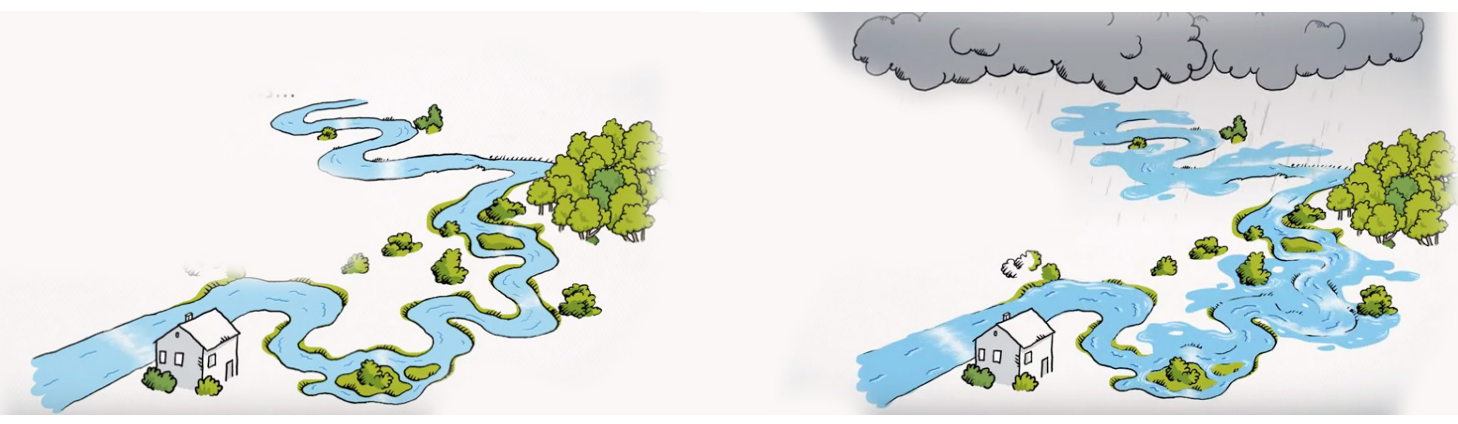

Fig 5.7 // A river naturally meanders which improves water quality and reduces flood risk. Flows are slowed and the peak of floods are delayed giving more time to prep.
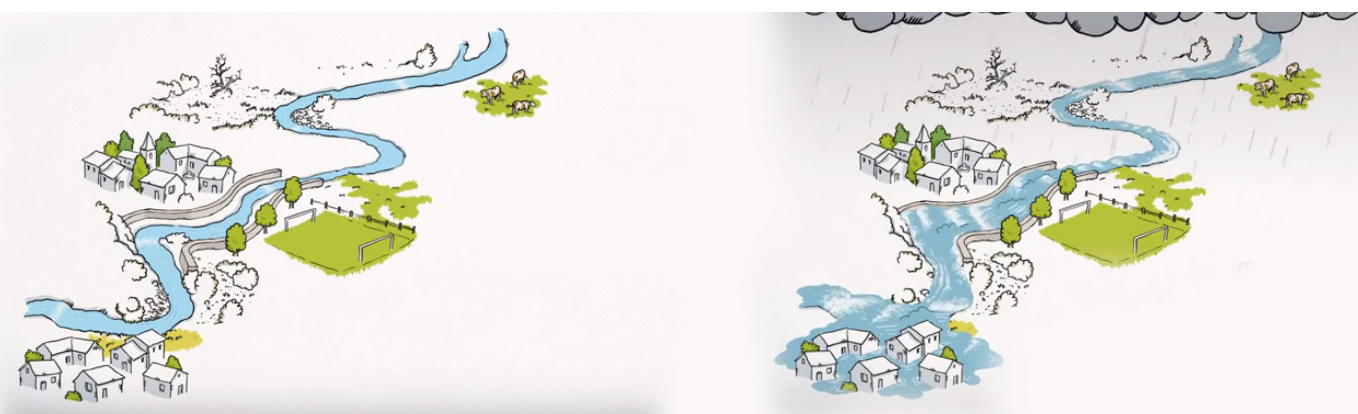

Fig 5.8 // Narrow river run to quickly and increases flood risk downstream
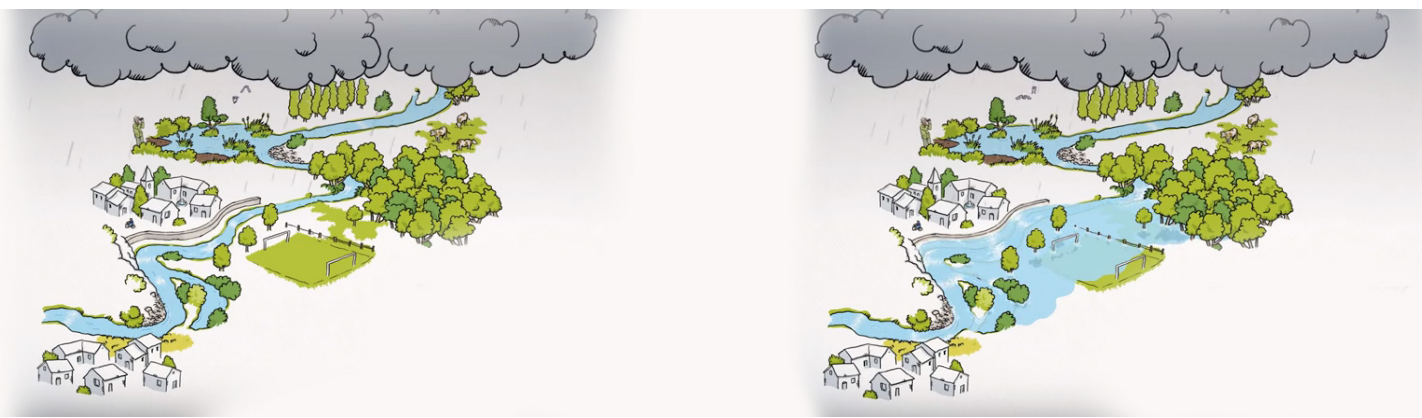

Fig 5.9 // Reconnecting the river with floodplains to protect vulnerable communities. 


\section{Natural Flood Protection}

Long before the development of any river floodplain area, streams and rivers would flood on a regular basis. This cleaned the stream of rubbish and deposited nutrients to the soil of adjacent land. Today, floods are seen as a hindrance, and we build walls and channels to move the water from them away from built up areas. This meant straightening of the rivers and streams, potentially lining them in concrete, but ultimately just move the problem. There is another way though.

\section{A more natural approach}

Natural flood protection methods offer a much more sustainable approach to dealing with floods over the current "Hard Infrastructure" methods. The BBC did an article on this in 2015 as the United Kingdom continues to deal with severe flooding. They say that "a combination of small-scale interventions with the aim of reducing the speed of the flow of converging water before it reaches larger rivers."(How Do You Stop Flooding? - BBC News) This form of intervention is great for smaller streams but a river needs larger scale approaches to deal with flood waters. On a larger scale, trees can help catch rainfall and take water from the soil allowing more water to penetrate it, but this is needed on a much larger scale to have a real effect on flooding of streams and rivers.

The Santa Clara Valley Water District offers three of many examples of natural flood protection methods that minimise impacts on the ecosystem and increase a creek or rivers capacity for flood waters. Crib-walls, overflow channels and bypass channels are the three methods mentioned by Santa Clara Valley. These methods are either aimed at strengthening the creek or river banks or their capacity.

Crib walls are made up of dead tree trunks built up along the banks of a river and then buried. Over time the logs will decompose and the root structure of planted vegetation on the bank will become a protection against erosion.

Overflow channels and bypass channels are a technique to increase the rivers capacity. Whereas bypass channels will never be seen as they are underground, and more a hard infrastructure technique. Large culverts divert water underground and run it under streets and homes. Whereas, overflow channels are visible, used when water flow is high and work parallel to the river.

\section{Reconnecting the river to the floodplains}

Maybe the best method of all is reconnecting the river to the floodplains. If a river is able to connect with natural floodplains, old channels, and less valuable land like sports fields, it can help to protect communities, preventing the cause of millions in damage to homes and businesses. These, and slowing the flow of the river through its natural meandering can improve water quality, improve biodiversity and reduce the risk of flood. But some rivers are beyond this point, and residential development has been built up too close to the edge of rivers and streams to be able to do anything with and other methods are needed. 


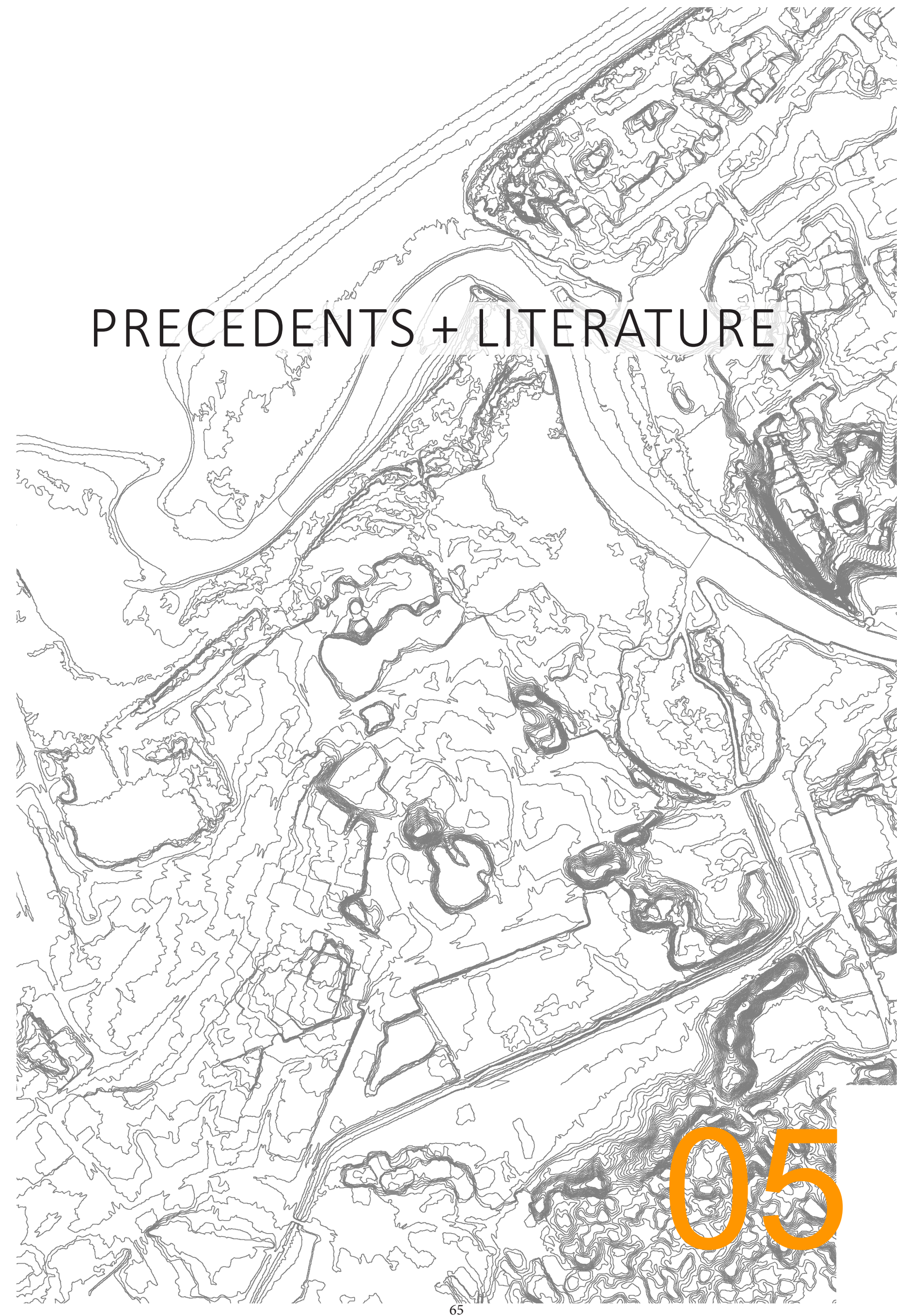




\section{Literature}

Despite our dependence on healthy ecosystems, society has made the decision to continue life as usual until a loss of valued goods and services is realised. Then, society will expect and rely on science to clean up the mess and make it look natural. Hilderbrand et al. 2005.

Humans have a take all, give nothing back relationship with this planet. But a shift is starting in this mindset. Rivers have meant livelyhoods for people all through history, providing potable water, transportation, irrigation for land and a renewable energy source. A healthy and functioning river can be very appealing and attractive to both residents and businesses as it does not just provide tourist benefits. A positive river system can have cost-effective flood control, improved water quality, reduced infrastructure cost and increase property values.

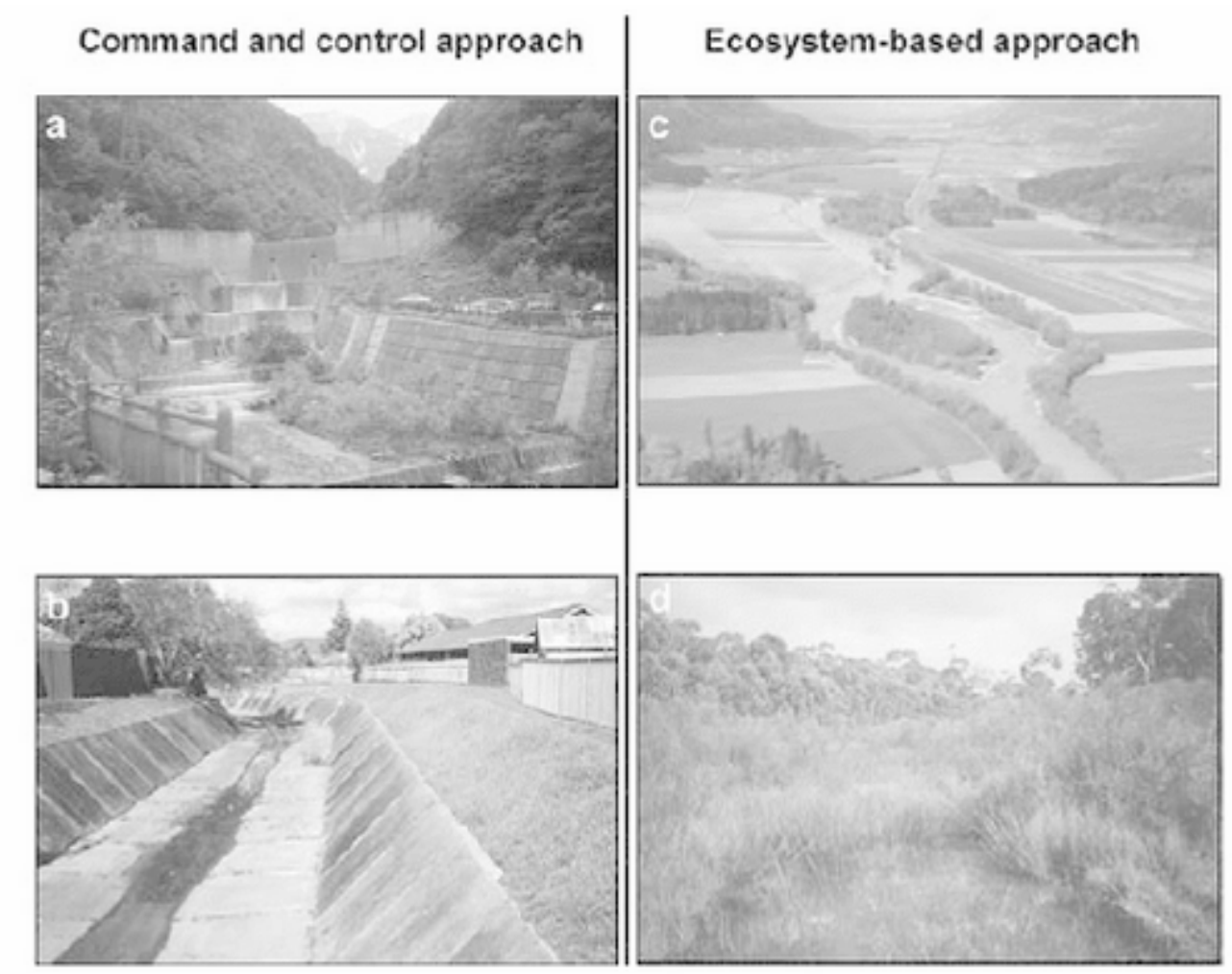

Ficura 1.1. Engincering- and ecosystem-based approaches to river management.

(a) Sabo damsarnd sediment maragement - Hokkaido, Japan (source: Kirstie Fryirs)

(b) "Stabilizing" rivers through urbanization and stormwater management-Cessnock, NSW (source: Kirstie Frivirs)

(c) Reinstating braided and anabranching chanrels along previously channelized rivers in "space to move" programs in Europe-c Jürgen Petutschnig (see chapter 11)

(d) Maintenance and enhancement of valley bottom swamps and wetlands-Barbers swamp, upper Shoalhaven catchment, NSW (source: Kirstie Fryirs)

Fig 6.1 // Engineering and ecosystem based approaches to river management. 
But, for any river problems, the general practice is the most practical and economical solution devised by an engineer. This generally involves the channelisation of the river which drastically alters the morphology of the river, which can be detrimental to the biology of the river. McHang proposed a 'design with nature' thought, working with the natural environment rather than against it, using living vegetation rather than artificial materials and hard scape.

However, with the case of some urban rivers, they are beyond the point of being able to work with the very little natural environment that is there. Brierley and Fryirs make the point that there is no turning back the clock, and replace what once was, and discuss the relationship of River Rehabilitation and River Restoration.

Their definition of River Restoration implies returning an aquatic ecosystem to a state as similar as possible to that which prevailed prior to human disturbance. So it refers to the repair of damage done to the indigenous ecosystem by humans in the hopes to re-establish the diverse and dynamic nature of that ecosystem. In contrast to this is its opposing idea, River Rehabilitation, which is a series of small-scale programs that aim to achieve a healthy and sustainable ecosystem with the conditions that exist.

The former of these two ideas could be said to come from a "command and control" approach. Channelising rivers, controlling them with man made structures and to benefit agriculture.

Environmental issues were ignored during this period and it was solely an economic concern. This slowly shifted after time to health and well-being of society issues and the natural ecosystem concern. But initial attempts to fix this failed and a new shift was needed.

A shift to an ecosystem perspective that does not attempt to control nature began to take effect. This approach aims to establish healthy resilient river ecosystems that can recover rather than resist. A healthy community, like a healthy body can only perform as good as its weakest part, and so a healthy river is a product of a healthy society and communities.

These texts have brought up a crucial issue with the thinking of this research. The aim has always been to restore the river to a pre-European system, but nature is a never to be repeated structure and there is no way of reversing time to do so. It has changed the thinking behind the project; "how can we make a healthy river ecosystem and in response a healthy social and economic ecosystem?". Because a healthy river is a healthy community. 


\section{River City}

\section{SLA \\ Gothenburg, Sweden}

As part of an international workshop to assist the development of Gothenburg City's central harbour, ten selected teams created a new vision for its future. SLA was a team leader for one of those ten teams at the international river city workshop. SLA and its team turned what was seen as challenges to the city of Gothenburg into opportunities and qualities they could work with.

The challenges that Gothenburg faced when this workshop was running were what many cities in the 21st century are facing today. Climate change and sea level rise on the banks of the Gotaalv River present flooding risk to the city centre. To make the city more resilient and on par with flooding risk interventions, preventing flooding will be integrated into the urban fabric to both protect the city and harbour including public life along the river this is another of Gothenburgs challenges.

Gothenburg is made up of small communities that don't interact together, the idea to solve this issue is to try and stitch the city together across the Gotaalv River. By creating bridges, floating houses, parks and public spaces along the river edge, the idea is that it will nurture social inclusion of the various cultures and generations to interact with each other. A segregated urban habitat will be changed by creating temporary meeting spots in areas on both sides of the river and the crossings of it too.

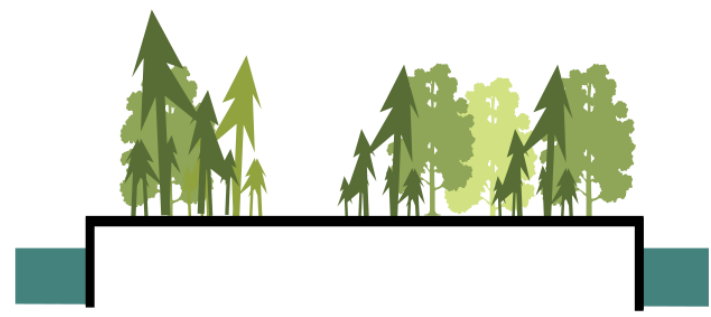

Go green, starting Monday!

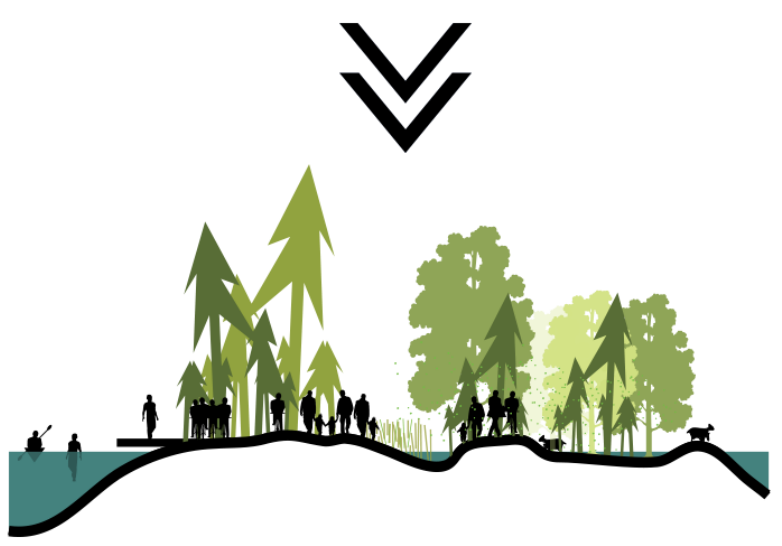

Inclusive

programming

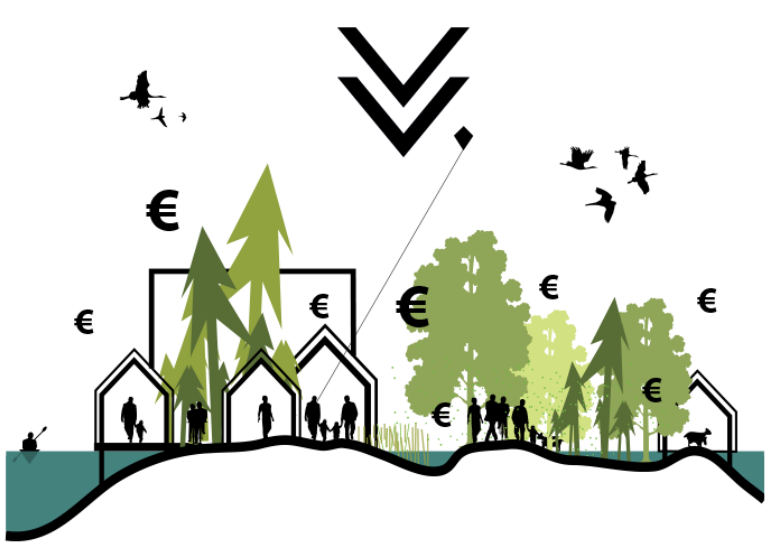

Dynamic

planning process 
SLA highlight the issue that "there is a tendency towards wanting to solve every issue in a master plan." Their solution is a dynamic process rather than a linear one that attempts to fix all issues at once. Using small interventions at those meeting spots, these can then be departure points for evaluating further development of the site. But first, as they put is to "Go Green, Starting Monday" meaning starting straight after the workshop, planting vacant plots of land and creating those temporary urban designs, then moving on to the inclusive programming and finally enhancing the quality and equity of the urban life.

Climate change is going to be an issue that Kapiti will also face in the future, if it isn't already. SLA's process of starting small, thinking big and scaling smart could be a strong process for the rehabilitation of the Waikanae River to follow. Starting small, beginning initially with small specific areas of the river targeted as being locations that would have the most benefit for minimising the effects of flooding. Thinking big. Thinking of the entire river corridor and how these initial sites may affect it once they are implemented. Scale smart, build up the next stage based on where it is needed.

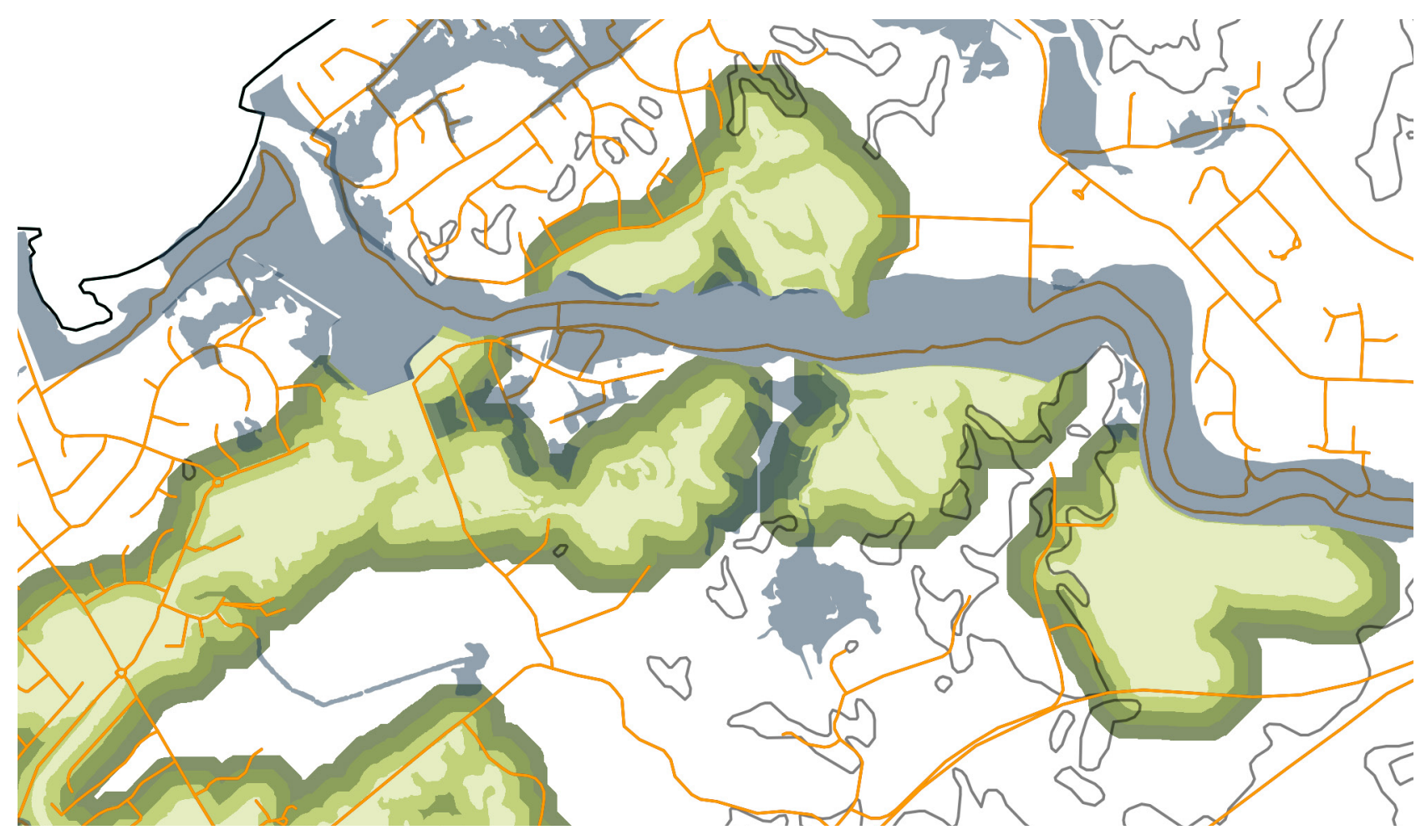




\section{Intermediate Natures}

\section{Michel Desvigne \\ Biesbosch Stad Rotterdam}

This project was created at the Architecture Biennale Rotterdam in 2005, and looked at the confluence of the Rhine and Meuse Rivers. Due to its location, it is under constant threat of flooding but the idea behind the project was to make room for water, re-naturalising the delta while at the same time constructing massive residential neighbourhoods for Rotterdam's development.

The site is currently surrounded by dykes and large dry areas used for farming. It once had meandering branch streams running through it before it was drained, filled in with noncompressing sand. The once boggy ground of the banks of these streams sank while the sand filled streams stayed uncompressed, and left them higher than the once banks, creating an inversion.

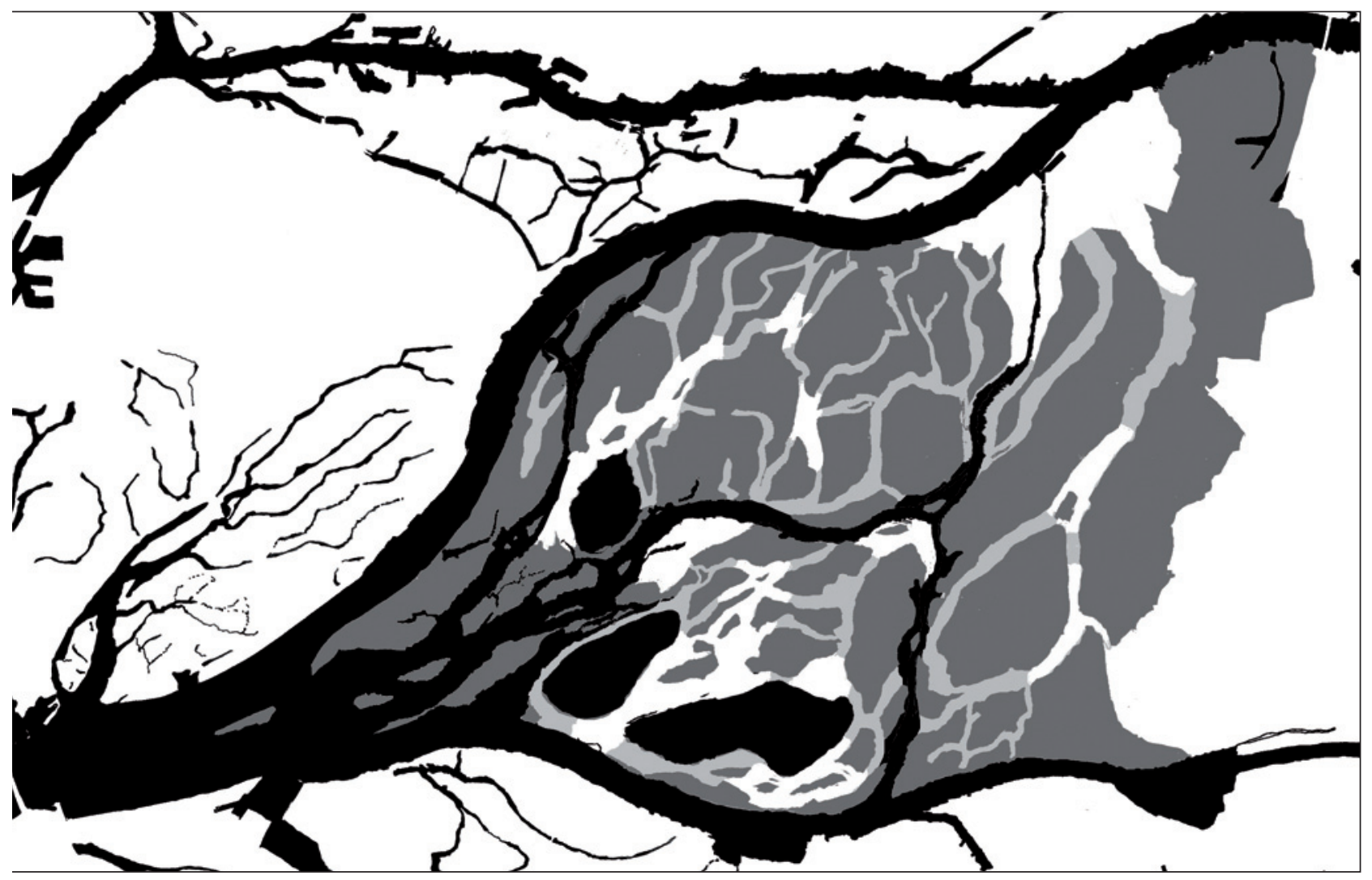




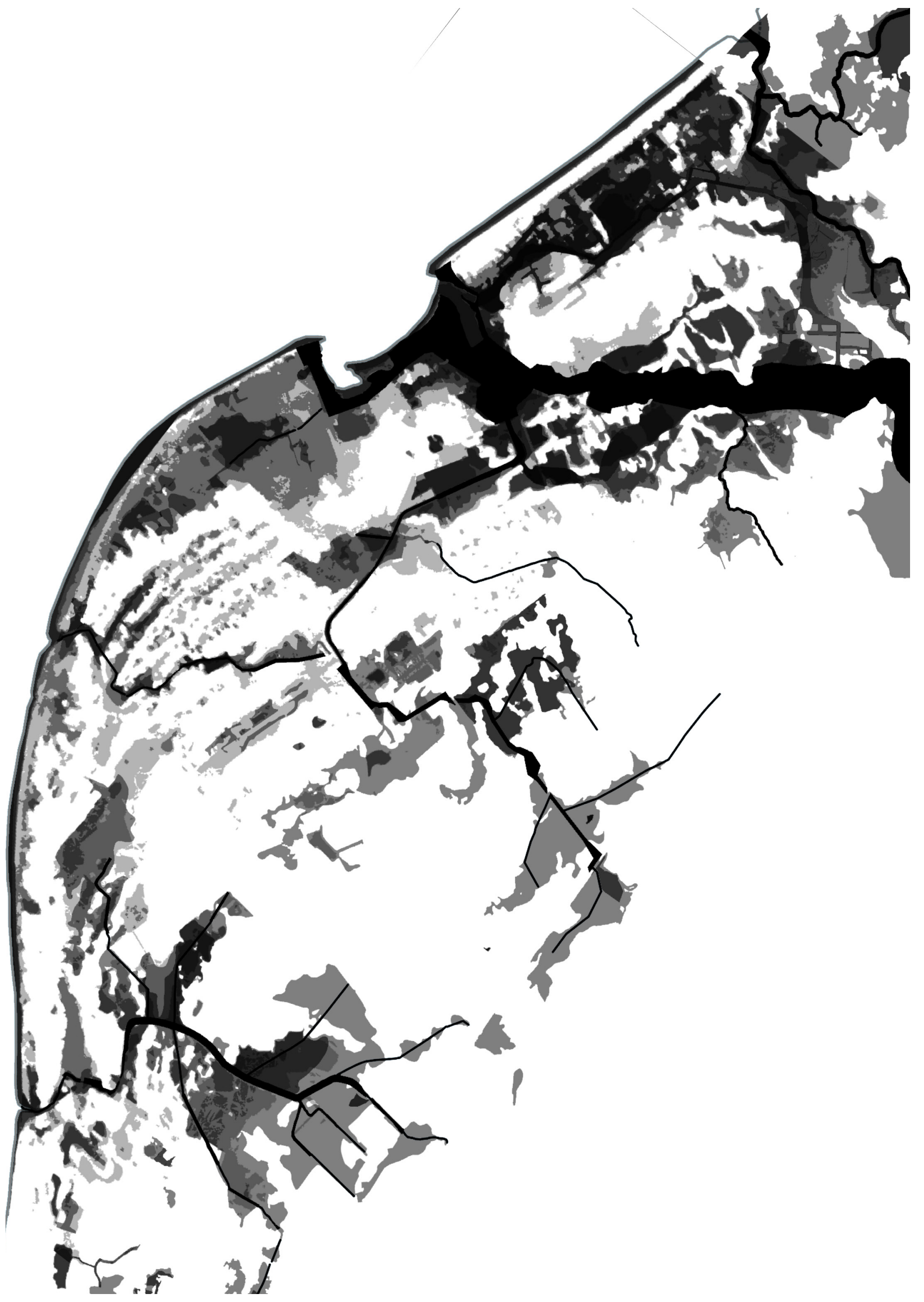

Fig 6.5 // Michel Desvigne, Biesbosch Stad Rotterdam, high ground low ground damage applied to Kapiti. 
The odd phenomenon was then enhanced with the idea to break down the dykes and move the materials atop the sand mounds creating dry areas in grey and white in fig 6.4. Without the dykes to stop the water it would be able to flow freely in floods - dark grey areas. This would leave spaces to live on, not behind the dykes but atop the newly formed dry areas creating an archipelago like landscape which would continue to be farmland but be liable to flooding now without the dykes.

Desvigne calls this a "paradoxical assignment making room for water while at the same time creating scenarios for massive construction of residential neighbourhoods". Which is what may need to happen along the Waikanae River. Currently, the river is trying to make room but it is unwanted as it causes great damage to homes and business during floods. But, what if it were allowed to? Able to flow freely across areas like farmland, sports fields and bush land. Giving the water a place to go that isn't so life threatening may solve some issues, and from this, residential areas could be built up from the high grounds.

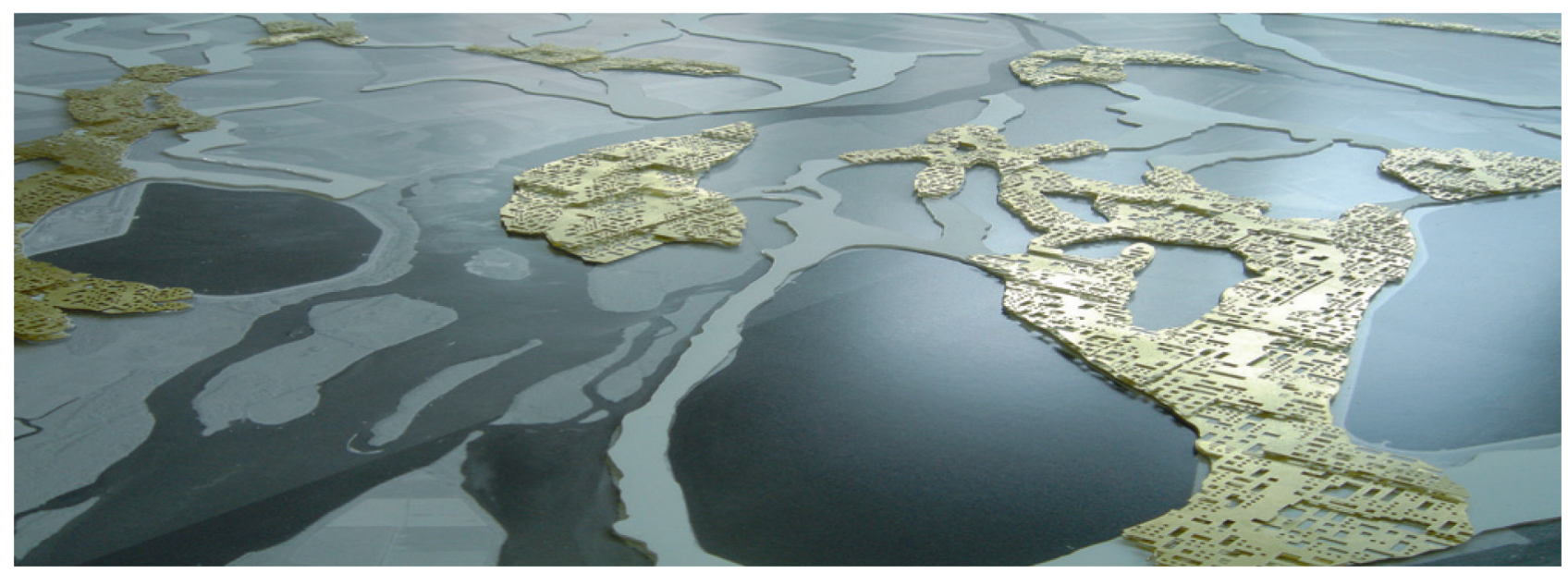

This interesting series of events that are happening in this project of Michel Desvignes could easily be applied to Kapiti. Although the two sites are hydrologically different, in ways they are working in similar fashions. Desvignes site has no issues with flooding but the idea is to let it flood where Kapiti has an issue with flooding and it is not really wanted. But, both in the future will grow and need that extra land and these high ground areas are going to be the only safe places along the river edge. 


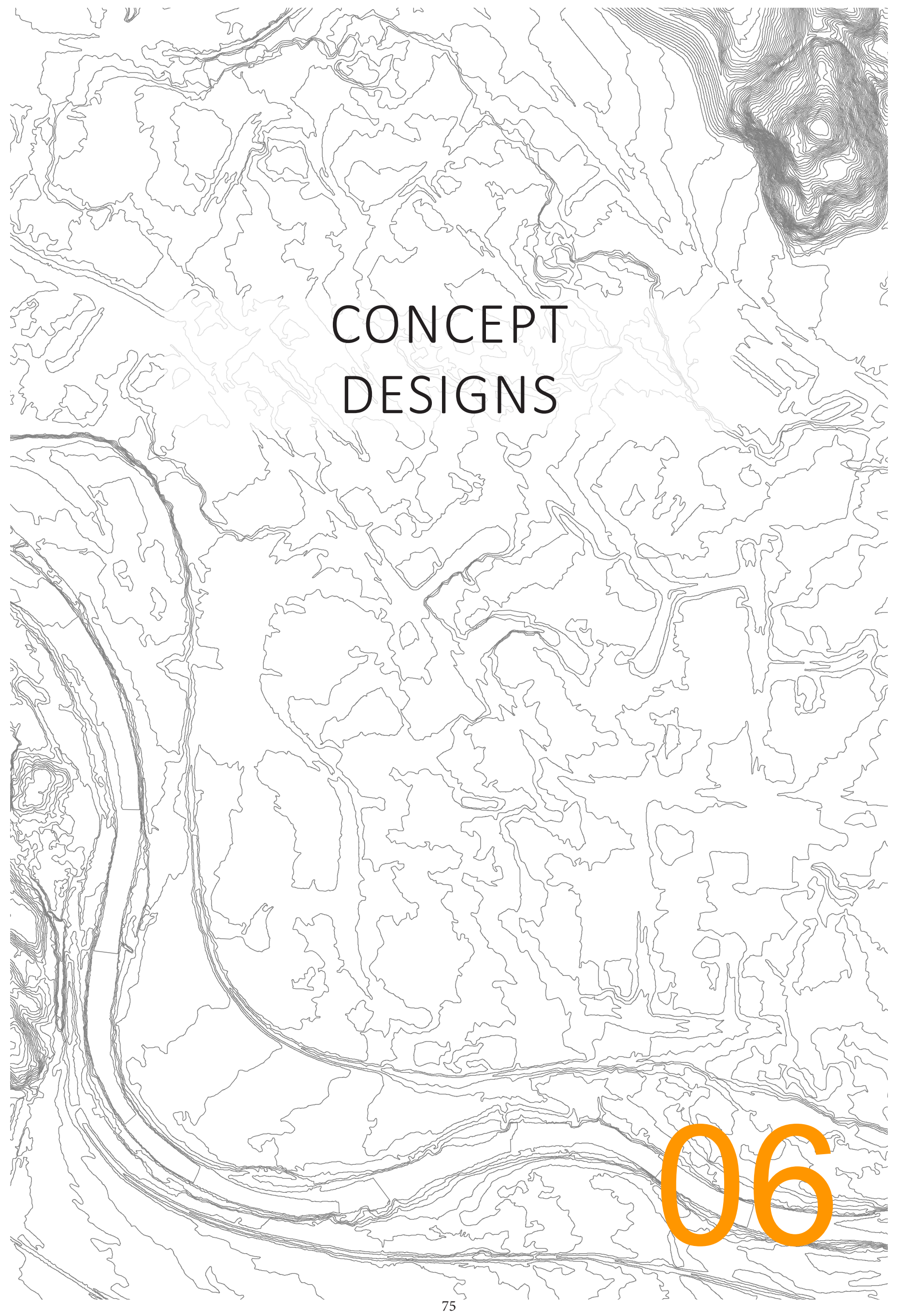




\section{Ecological Corridor}

The second phase of concepts still had its two defining factors to deal with, flooding and settlement. Yet they were approached from a different perspective. Within trying to re-understand the site after the initial concepts, the importance of the Waikanae River to its location was made. To the district of Kapiti, it is seen as a mountains to sea ecological corridor linking the Tararuas with the Kapiti Marine Reserve. However, by looking at how special those two locations are, and then back to this linking band, the connection is only just there. The Waikanae River is not celebrated as what this title gives it.

The new series of designs went by re-naturalising the river corridor and implementing natural flood protection methods along the Waikanae River. The initial focus area was Otaihanga. A small settlement at the mouth of the Waikanae River, it being probably one of the worst affected areas along the river with its close proximity and the river mouth having tidal effects on the flood waters as well.

There is an area of farmland that runs behind Otaihanga and wraps around it joining to the estuary on the other side. This area is designated as an overflow path, where water from the river flows when there is too much in the river corridor. This was perhaps an existing channel in the past and the reason why there are no buildings in the area.

Concepts started as a combination of re-naturalising the river corridor by heavily planting the river and adjoining streams with functional activity spaces, sports fields, playgrounds, etc. Large areas for activites that would not matter if flooded because they would most likely be called off due to the conditions. These areas would be those that would draw people to engage with the site. In floods, these areas would be used as storage systems for flood waters.

Concepts slowly moved away from this by having more vegetation and less activity to slowly evolve into a forested reserve, heavily planted in native vegetation in an attempt to restore something that may have once been present pre-European settlement. The hope for the heavy planting of certain areas would be that it would catch more of the water that falls as rain and still move the water away from the river and store it during a flood yet still attracting residents and visitors to explore the native forest. The problem with a revitalisation project like this, with the aim to aid flood protection, is that for any progress or effect on flooding large areas, the entire river corridor would need to be restored. 




Fig 7.1 // Top // Overflow corridor concept 1 sports fields and forest. Access road in orange. Dual use space, sports fields are sacrificial when overflow path is flooded.

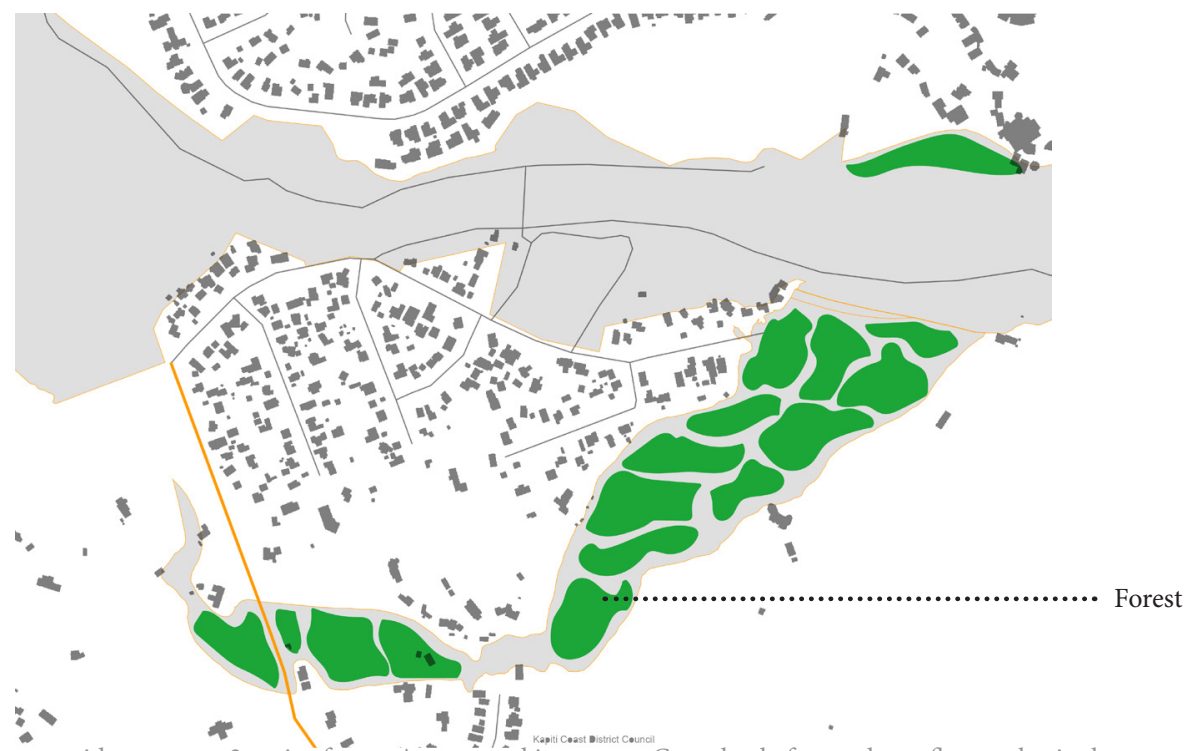

Fig 7.2 // Middle // Overflow corridor concept 2 native forest. Access road in orange. Completely forested overflow path, single use on just flood diversion.

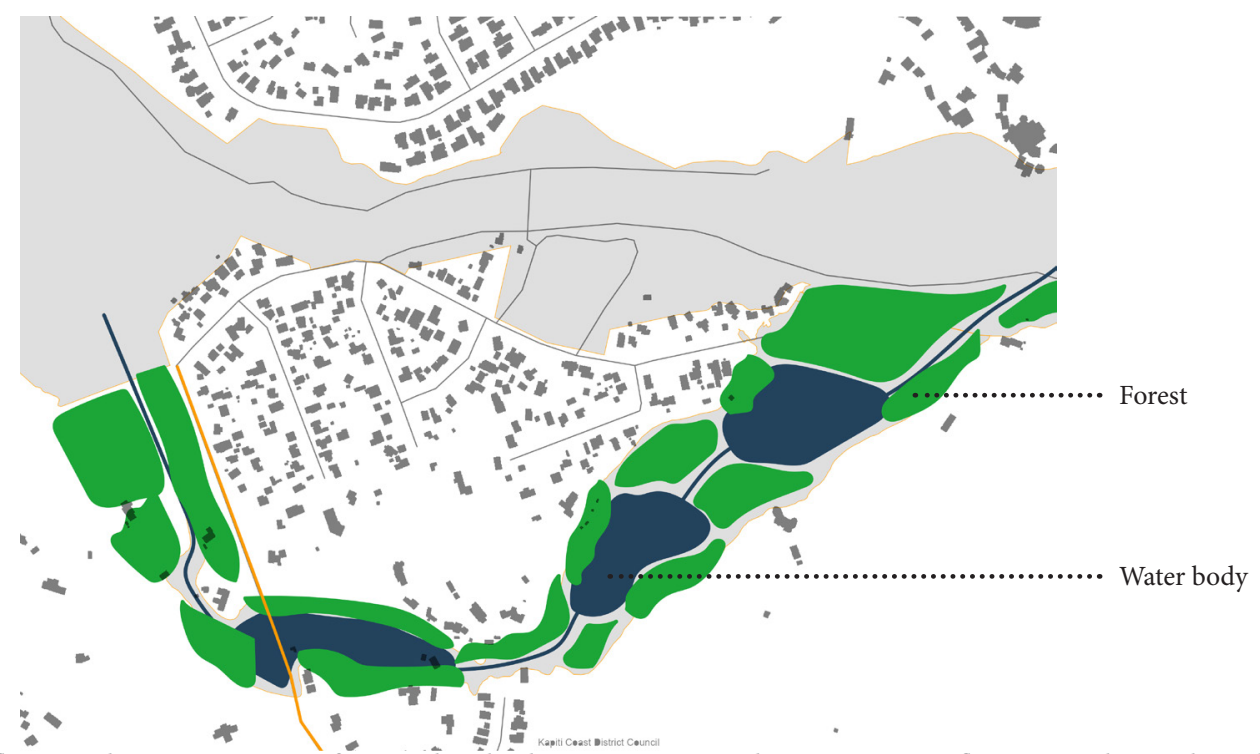

Fig 7.3 // Bottom // Overflow corridor concept 3 native forest and wetland system. Access road in orange. Water flows across the site through the forested overflow path. 


\section{Exploration Sketches}
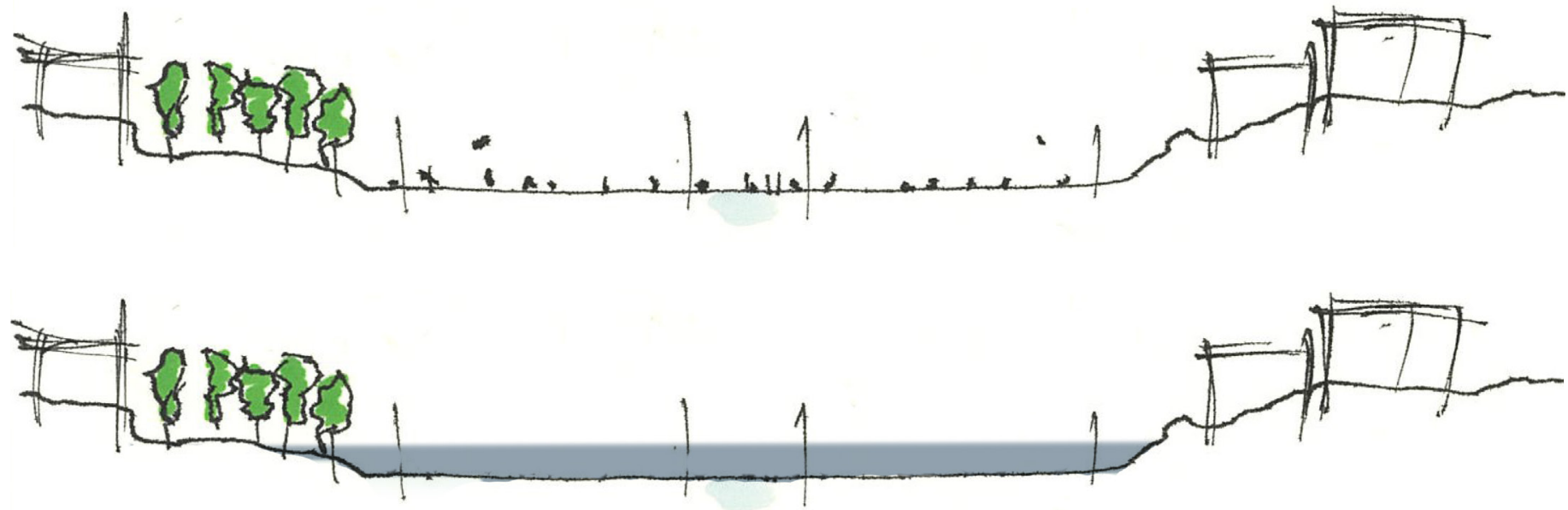

Exploration 1: Sports fields unflooded and flooded. Sports fields will not be used during flooding so perfect location in the overflow path.
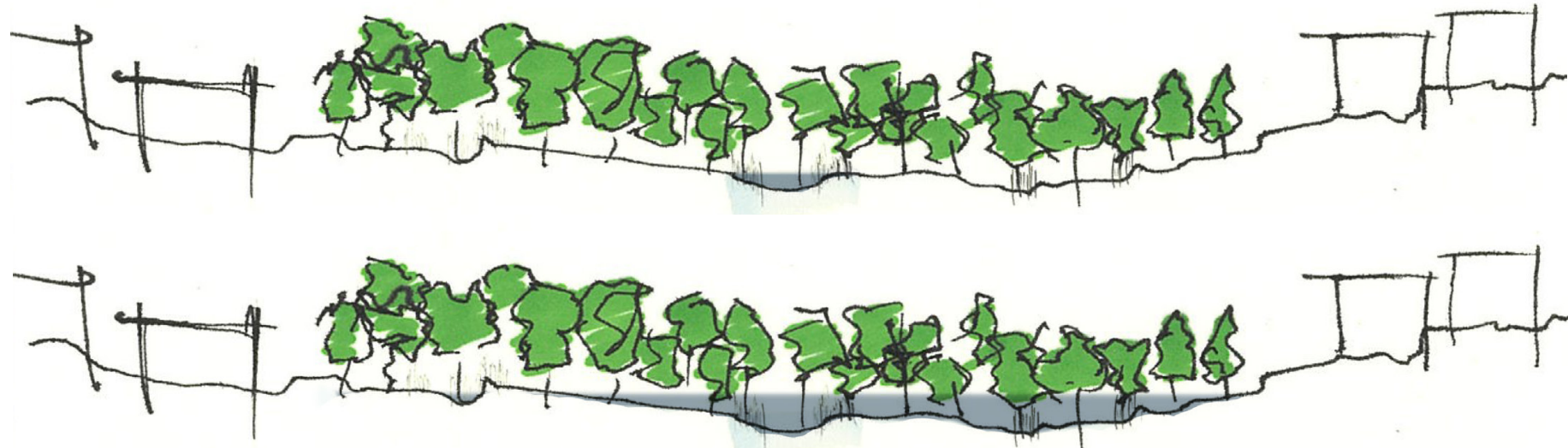

Exploration 2: Native forest unflooded and flooded. When flooded vegetation will slow flow of flood waters, reducing impact downstream.
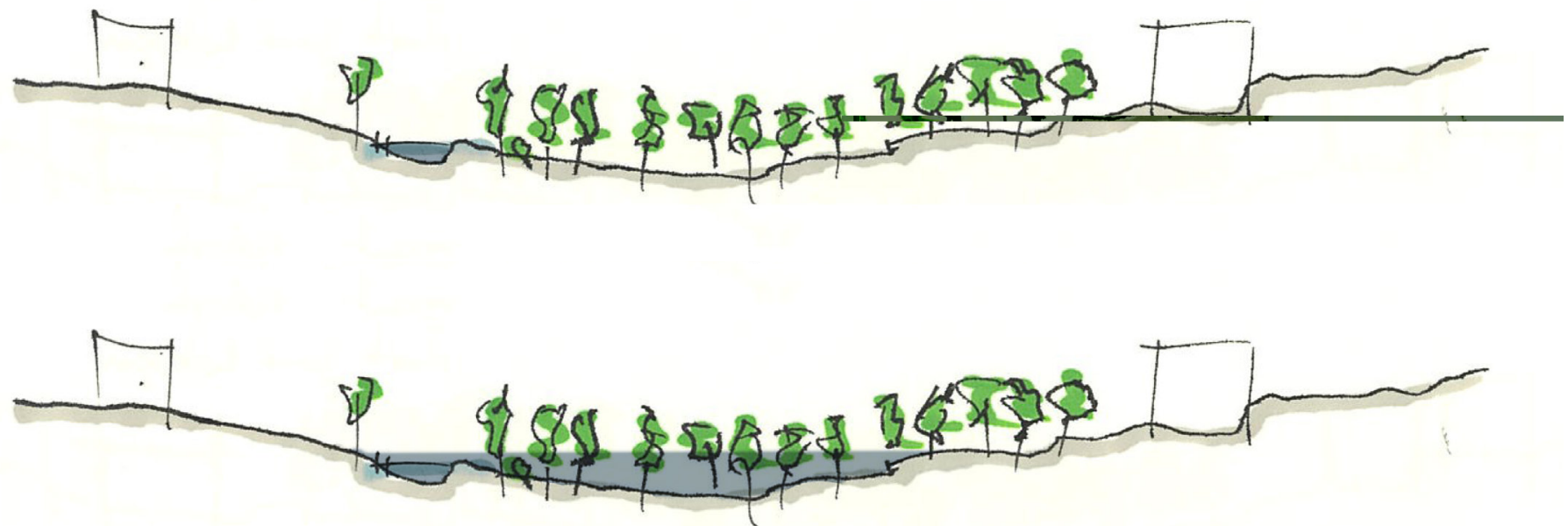

Exploration 3: Overflow stream unflooded and flooded. Stream running through site will flood out into forest slowing flood flow. 


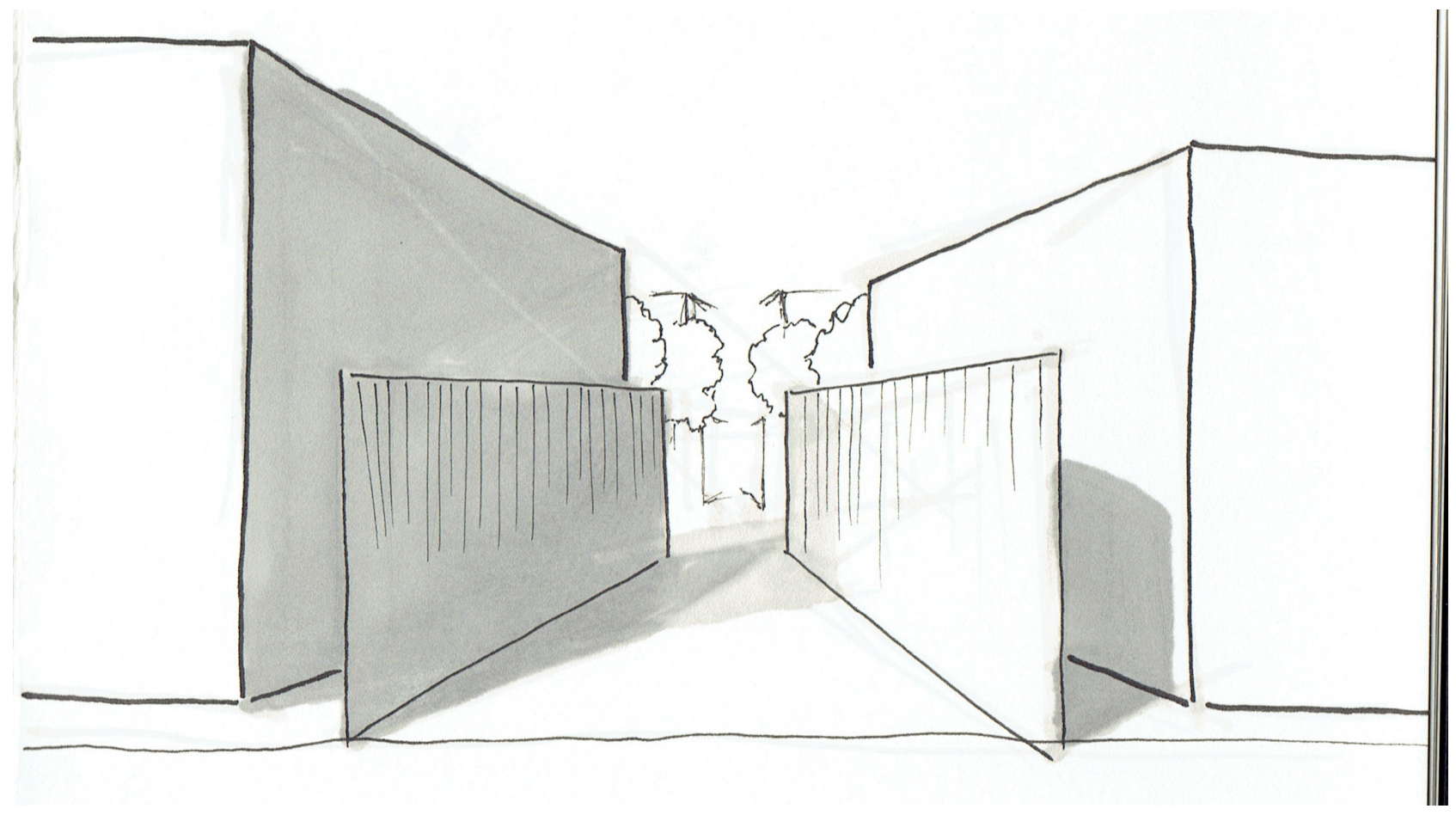

Transition from road between houses to overflow park.

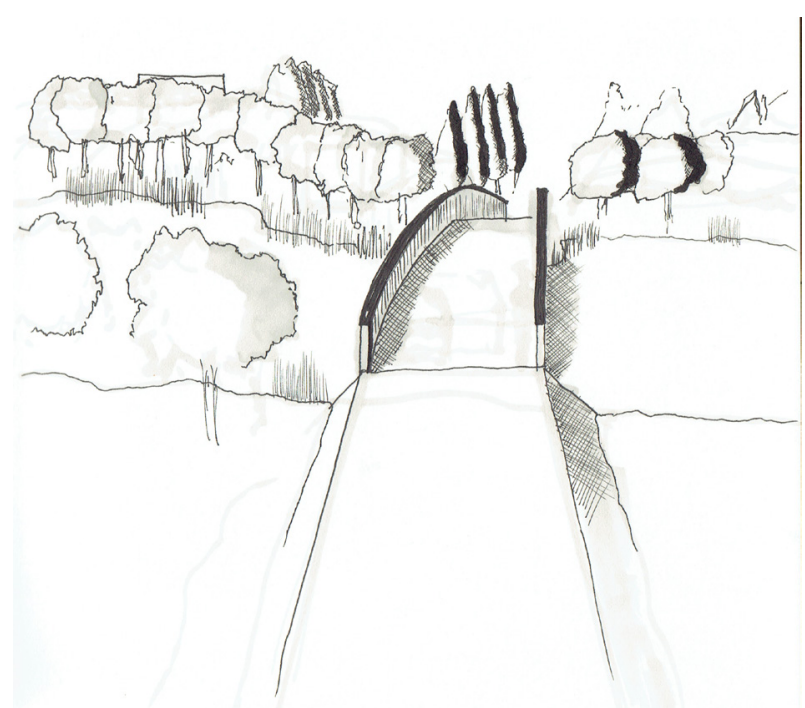

Relationship between road and the ecological corridor.

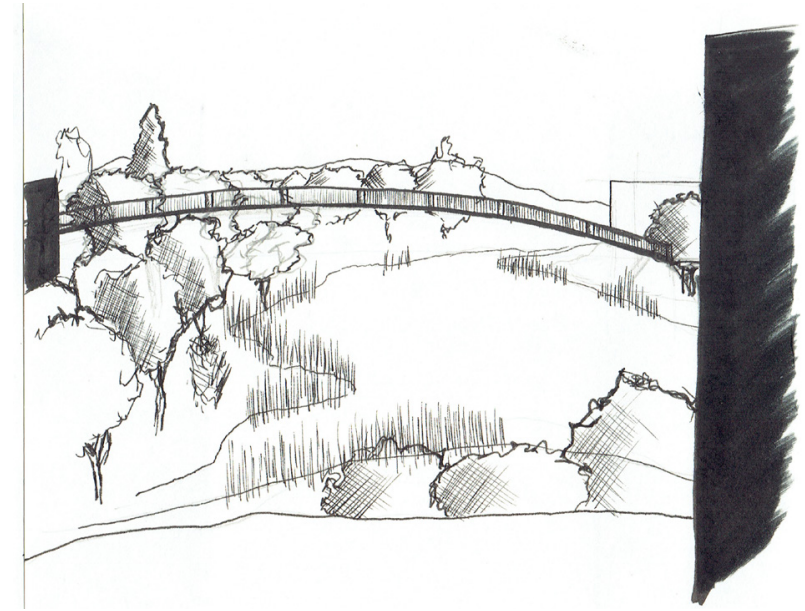

Road and ecological corridor relationship.

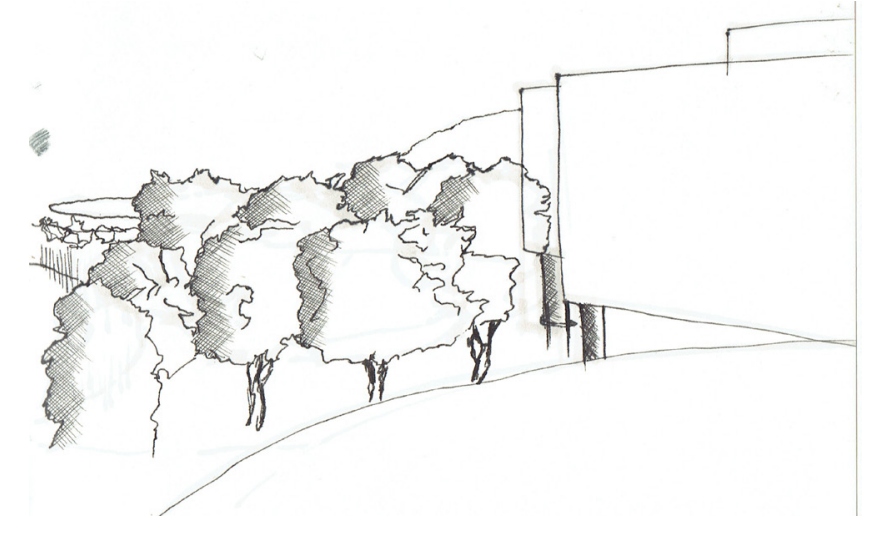

Ecological corridor and housing relationship.

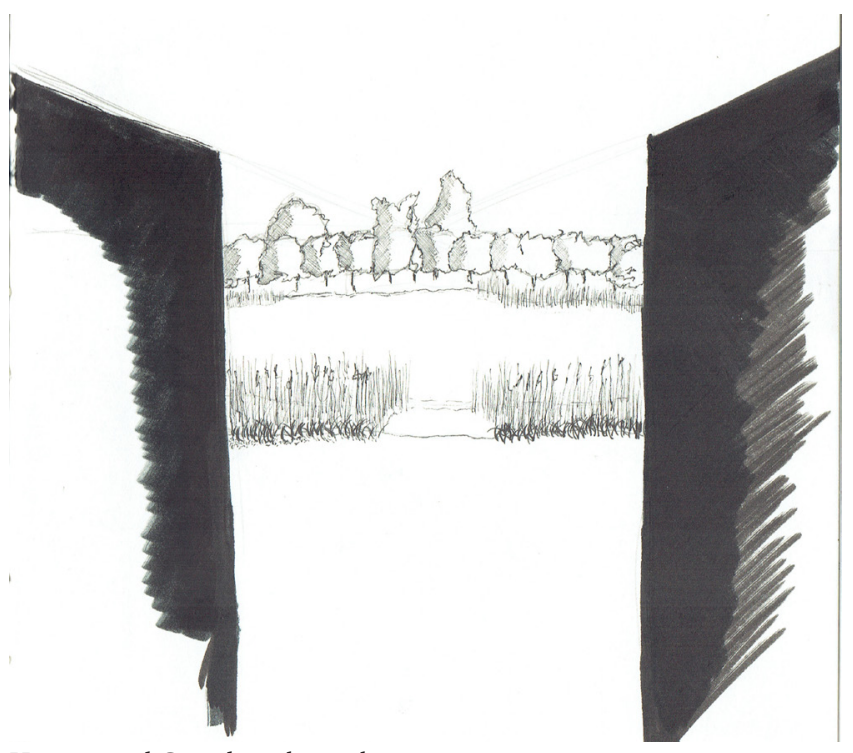

Housing and Corridor relationship.

Fig 7.4 // Series of exploitative sketches to understand the design moves and thinking throughout the process. 


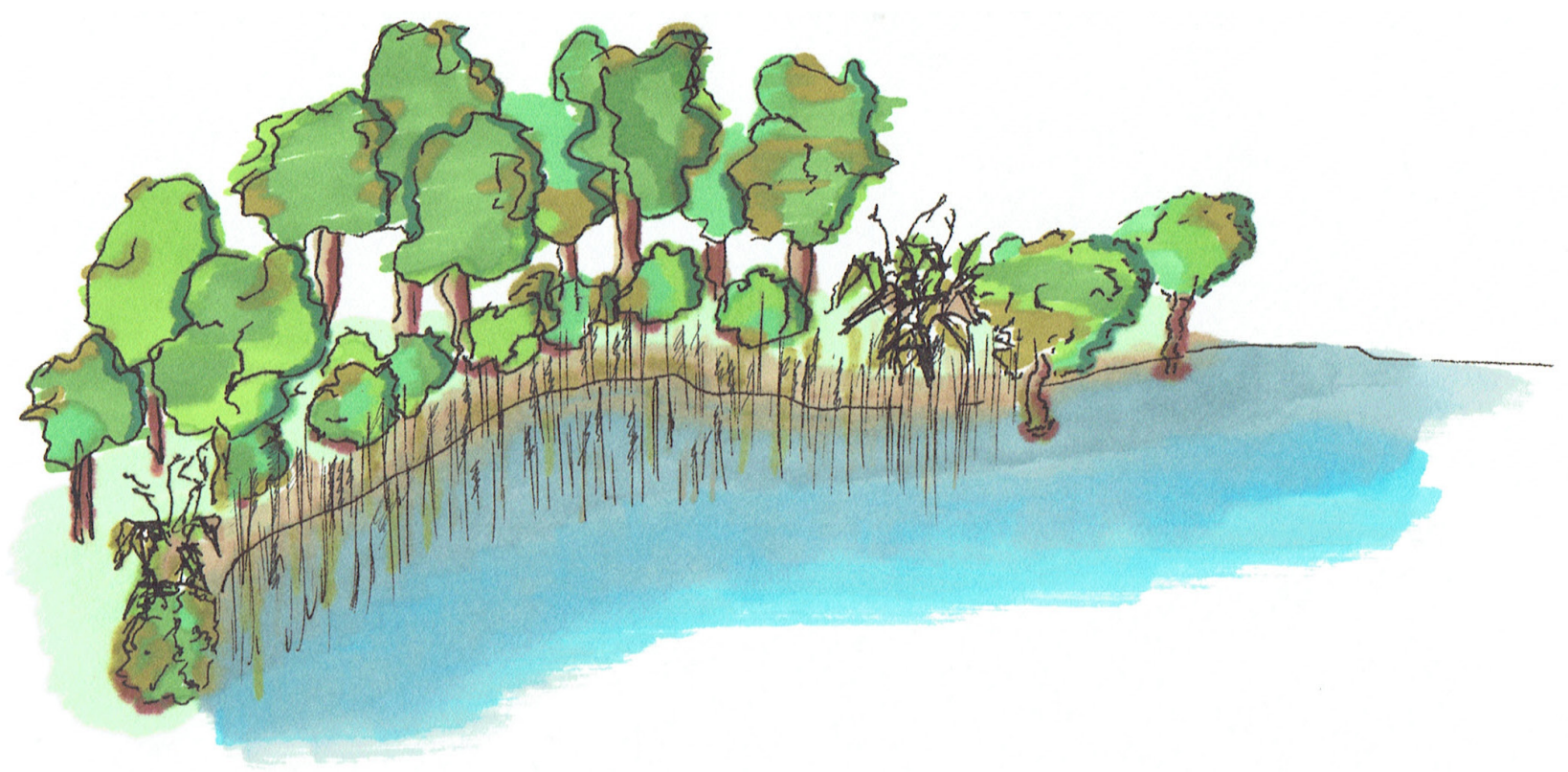

Ecology edge
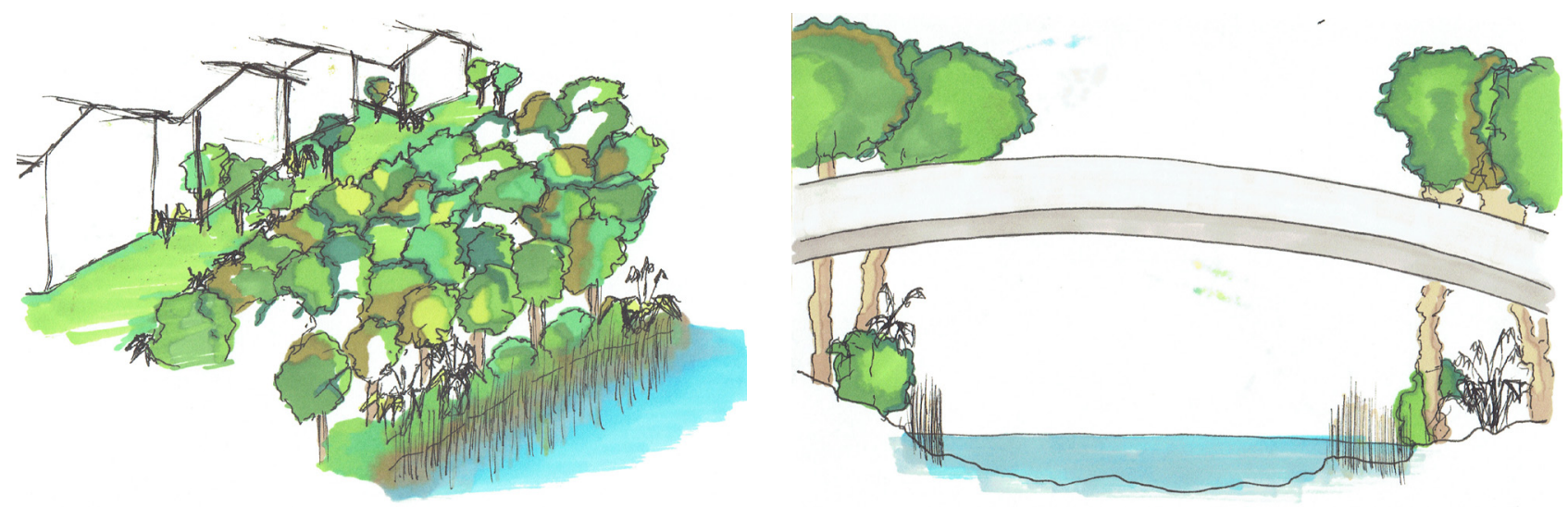

Housing and ecology edge

Road and ecology relationship

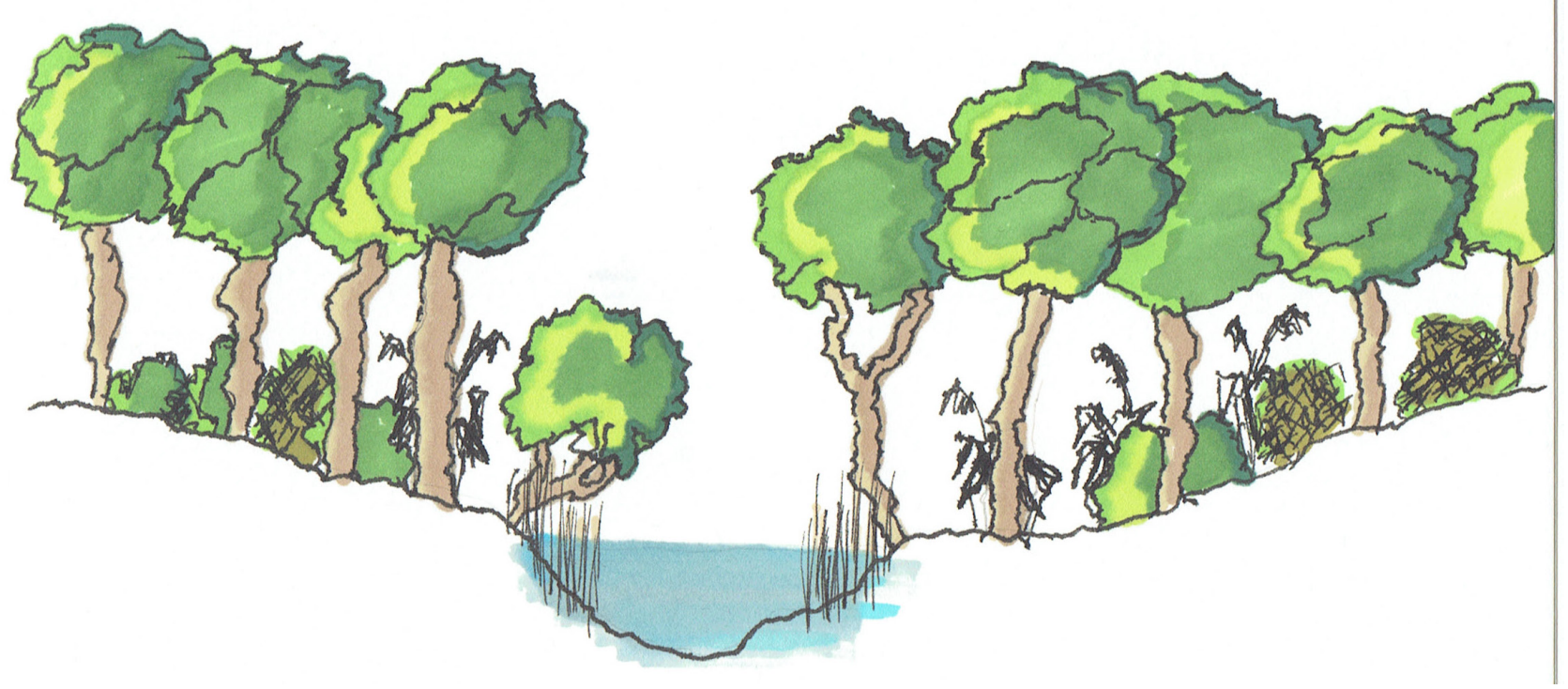

Waterway and ecology relationship

Fig 7.5 // Series of exploitative sketches to understand the design moves and

thinking throughout the process. 


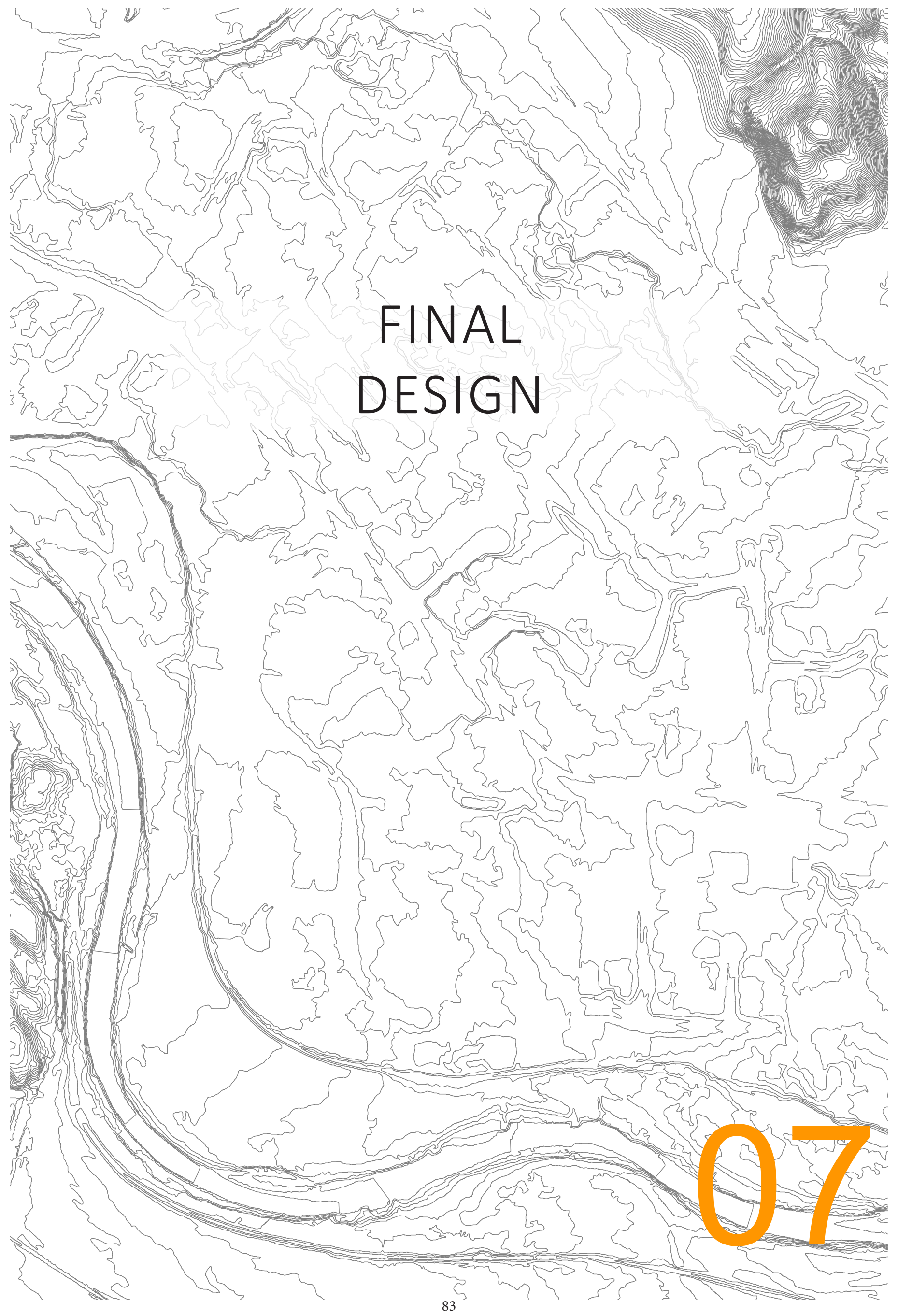




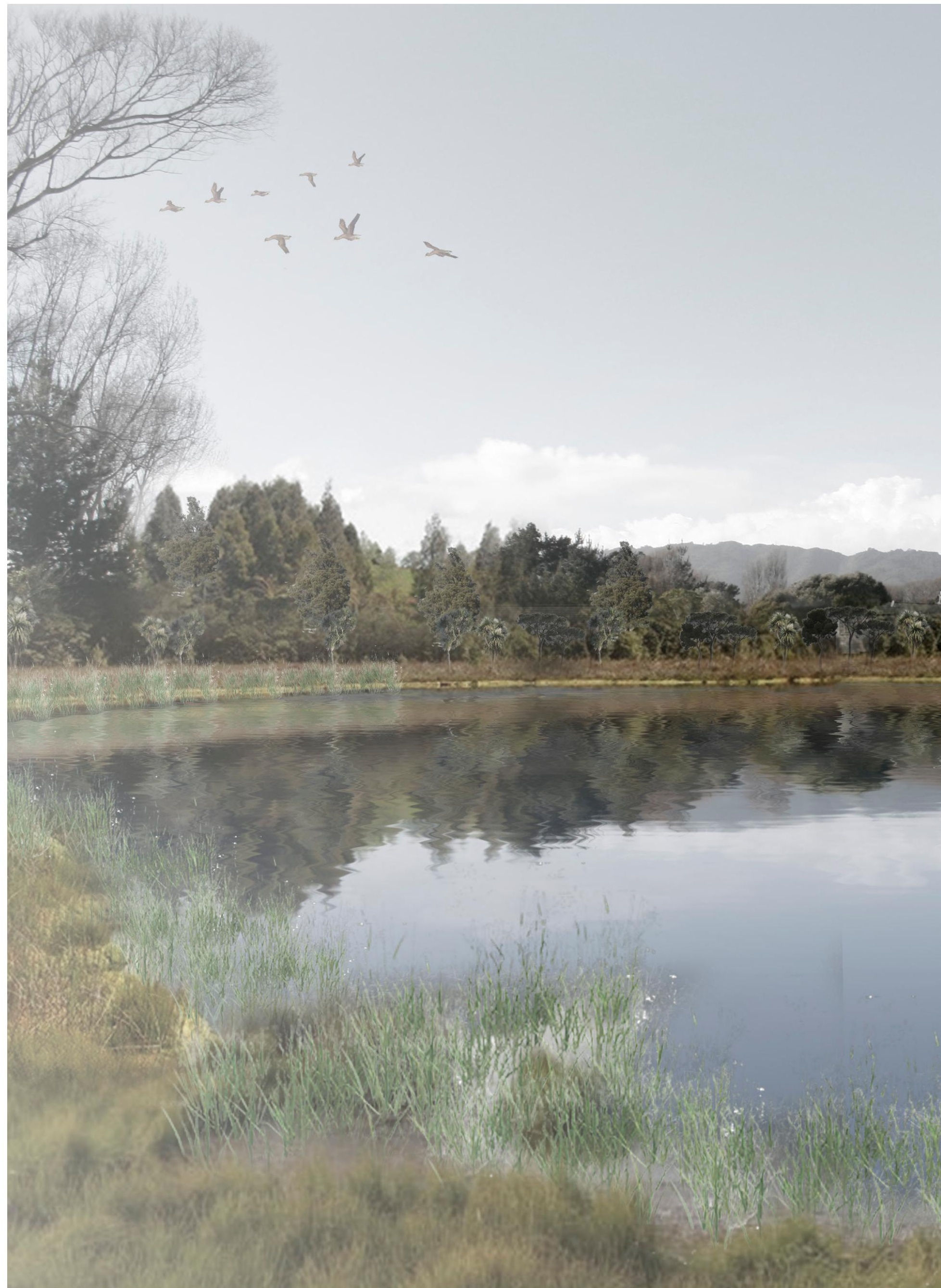




\section{Final Design}

The Waikanae River is an important ecological and social asset to the Kapiti coast. It is the link between the Tararua Ranges and Kapiti Marine Reserve out to Kapiti Island. Socially it provides great recreational value to Kapiti with great walking tracks, swimming holes and plenty of fish species to try and catch if you can. But it's such a destructive feature when it floods causing so much damage and doesn't have the same presentation that the other features of the ecological corridor have.

Alone, one site of change would do very little. Multiple large sites along the river corridor would be needed to make a great difference, and if the river is slowly changed over time it will work. One day it will become one large machine, built up of many smaller components. 


$$
3-2
$$




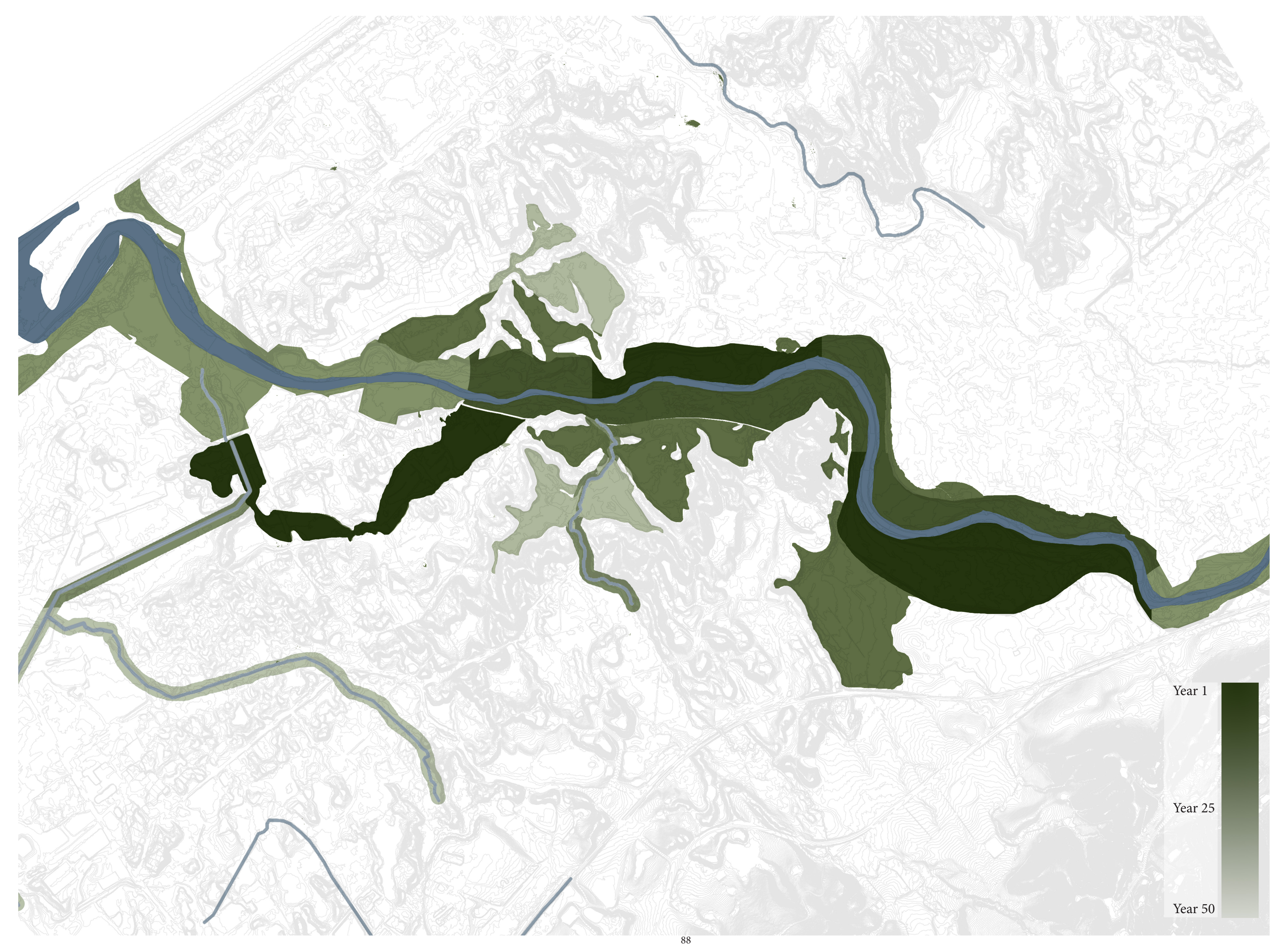


Staging the Design

For the best possible outcome for the river and the communities around it, for the revitalisation of the river to have any lasting effect on how the river floods, the entire river or at least a large portion of it would have to be changed. To do this all in one go would become a huge undertaking. Vast areas of planting would have to mature too before they function optimally in flood control. To begin with, these areas would require regular maintenance to help them along and reduce the risk of vegetation loss until they mature, but this can be worked around if done periodically.

A key idea from the River City project was their staging of the design, starting small, thinking big, scaling fast. This issue of the flooding of the Waikanae River cannot be solved in one move, it needs to start small. Small for a river scale. Because for this to work properly large portions of the riparian zone need to be re-established. Starting small means you can focus on a single area and put $100 \%$ into it at once, rather than doing 100 things at $1 \%$ of the productivity.

The idea is that three locations will be the initial starting points for further expansion of the design Once the three locations have reached a point at which they can function alone, a new layer of revitalisation can be added and another after that until complete. Then once enough of the river is complete, settlement can start along the edge of the ecological corridor.

For the first stage of the river re-habitation process, three sites have been chosen to initiate the process. These sites have been selected because they are open areas along the river that flood regularly with the river. The three sites are the overflow path behind Otaihanga, Kuri Road Park and Otaraua Park. 


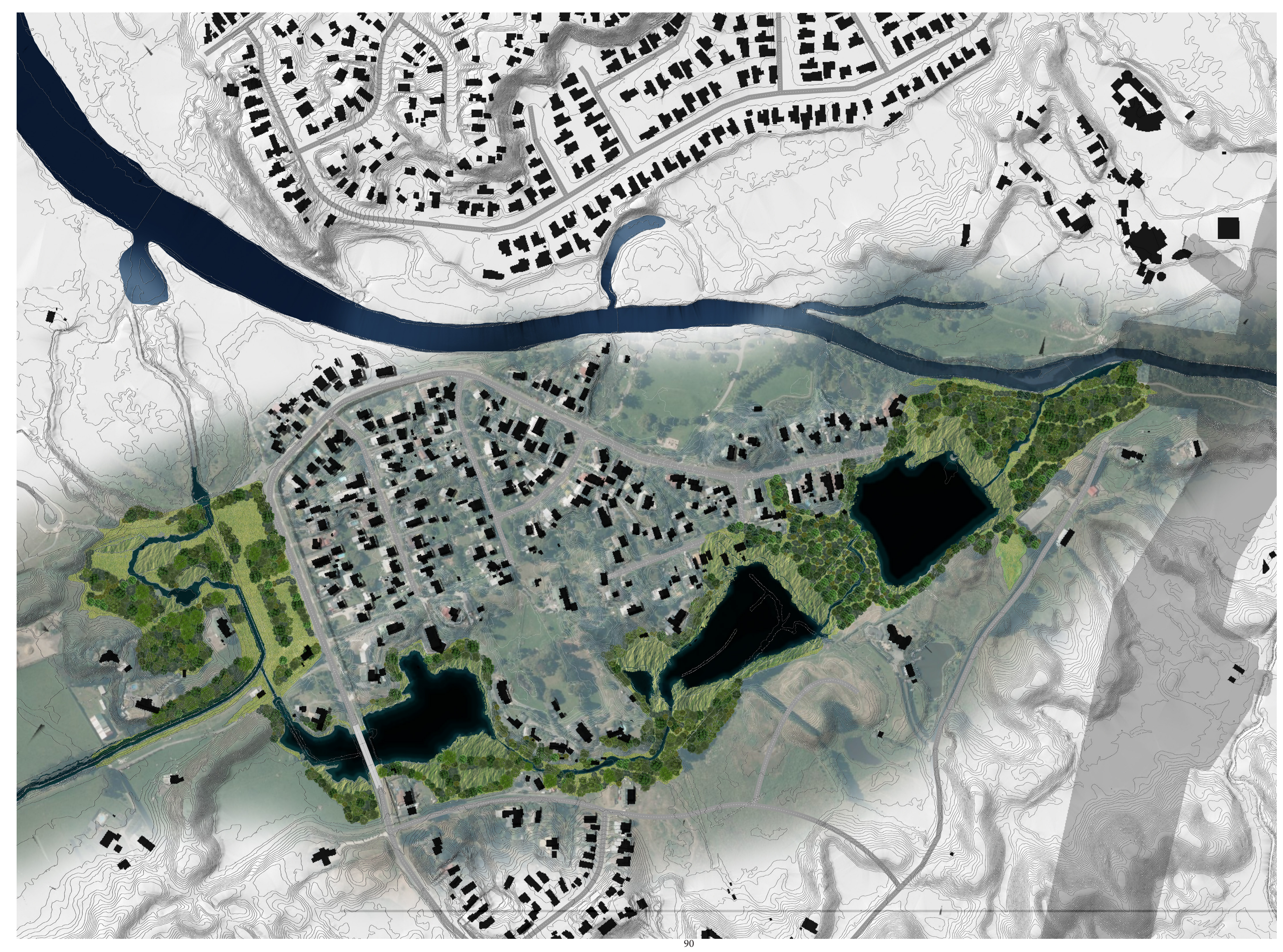




\section{Otaihanga Overflow}

The first of the three initiating sites wraps around the small township of Otaihanga. It is currently a low lying area between the main village and outlying dwellings that is clearly seen by locals as a flood zone. Utilising the overflow path that the river takes through this farmland, the design here is a series of wetlands and native forest that during a flood becomes a large water holding area, moving the flood waters away from the river. Holding it in the system for a period of time before it is passes through and exits out into the Waikanae River Scientific Reserve. At the other end of the overflow path it will go through a similar process before exiting into the river again and out to sea.

Soil from the centre of the site that is removed to form the lakes, will be relocated to the outskirts of the site in areas that are lower than the rest, as dual protection creating a hybrid of natural and structural flood protection. For the site to function on a day to day basis outside of a flood, an inlet to the site will need to be created to feed the lakes from the Waikanae River. This should also help encourage the flood waters to flow onto the site rather than letting it get to a tipping point before it overflows.

The sections in the overflow path will be lowered, and removed soil will be used to build up the surrounding edges of the site, creating a hybrid of natural and structural defence. To allow the site to function outside of a flood event an inlet on the Waikanae River will be built to encourage water to flow through the site on a regular basis as well as in a flood event.
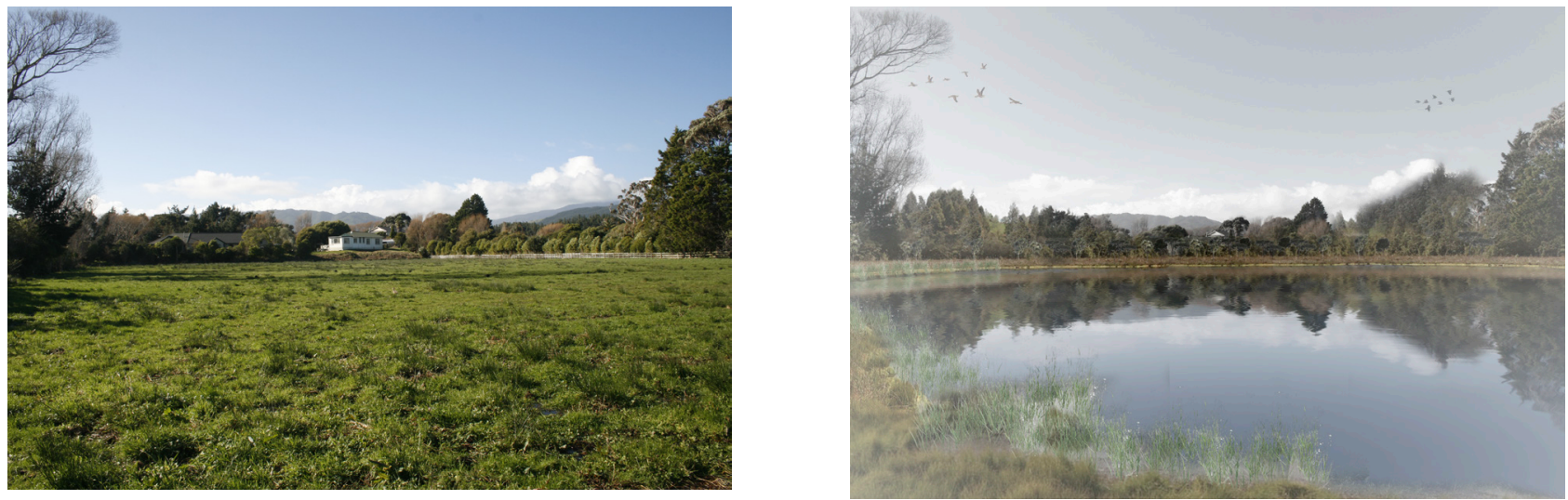

Fig 8.5 // Left Image // How the site looks currently, site is currently farmland. Farmland naturally floods, at time image taken ground was very saturated. 


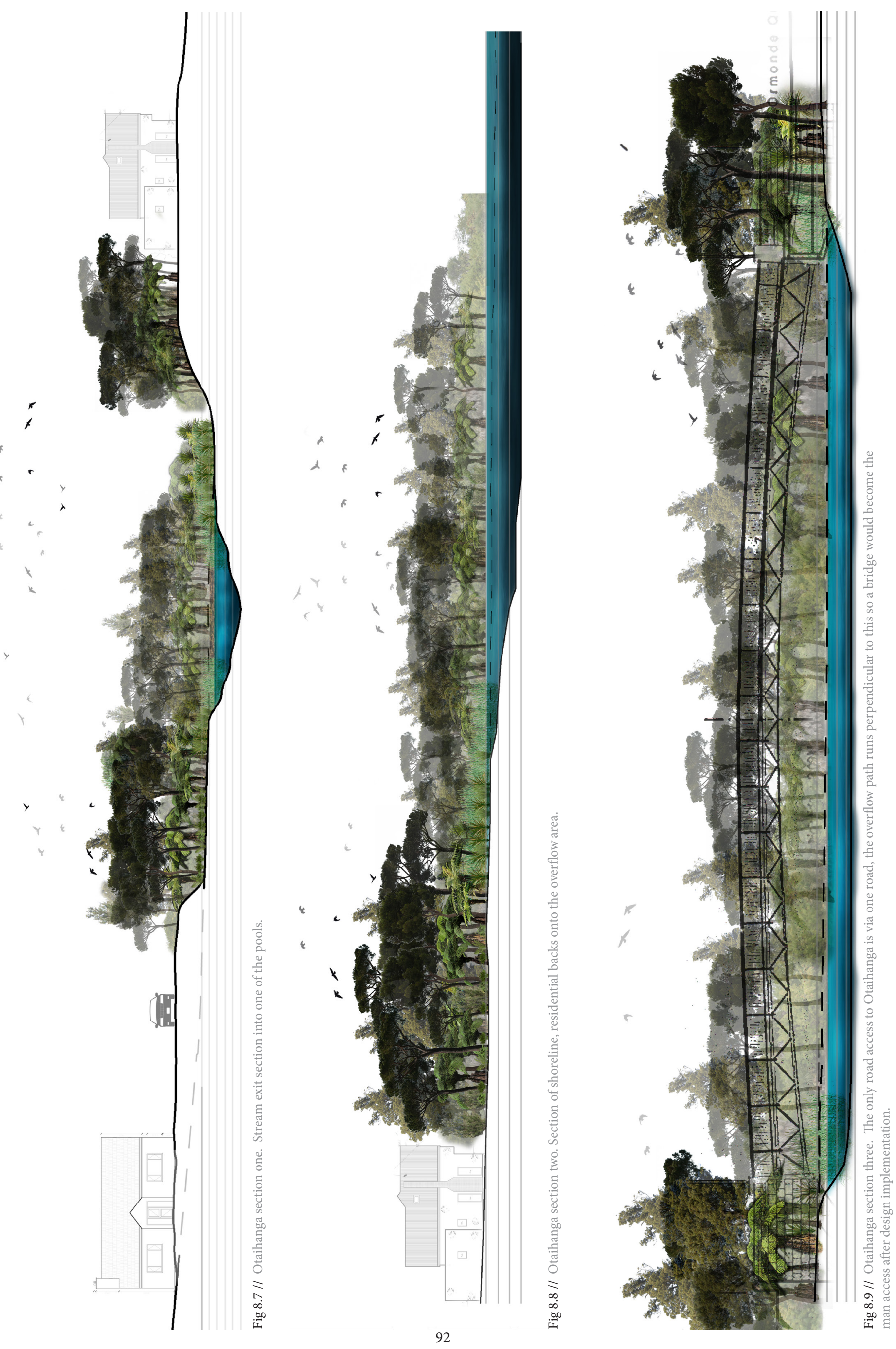




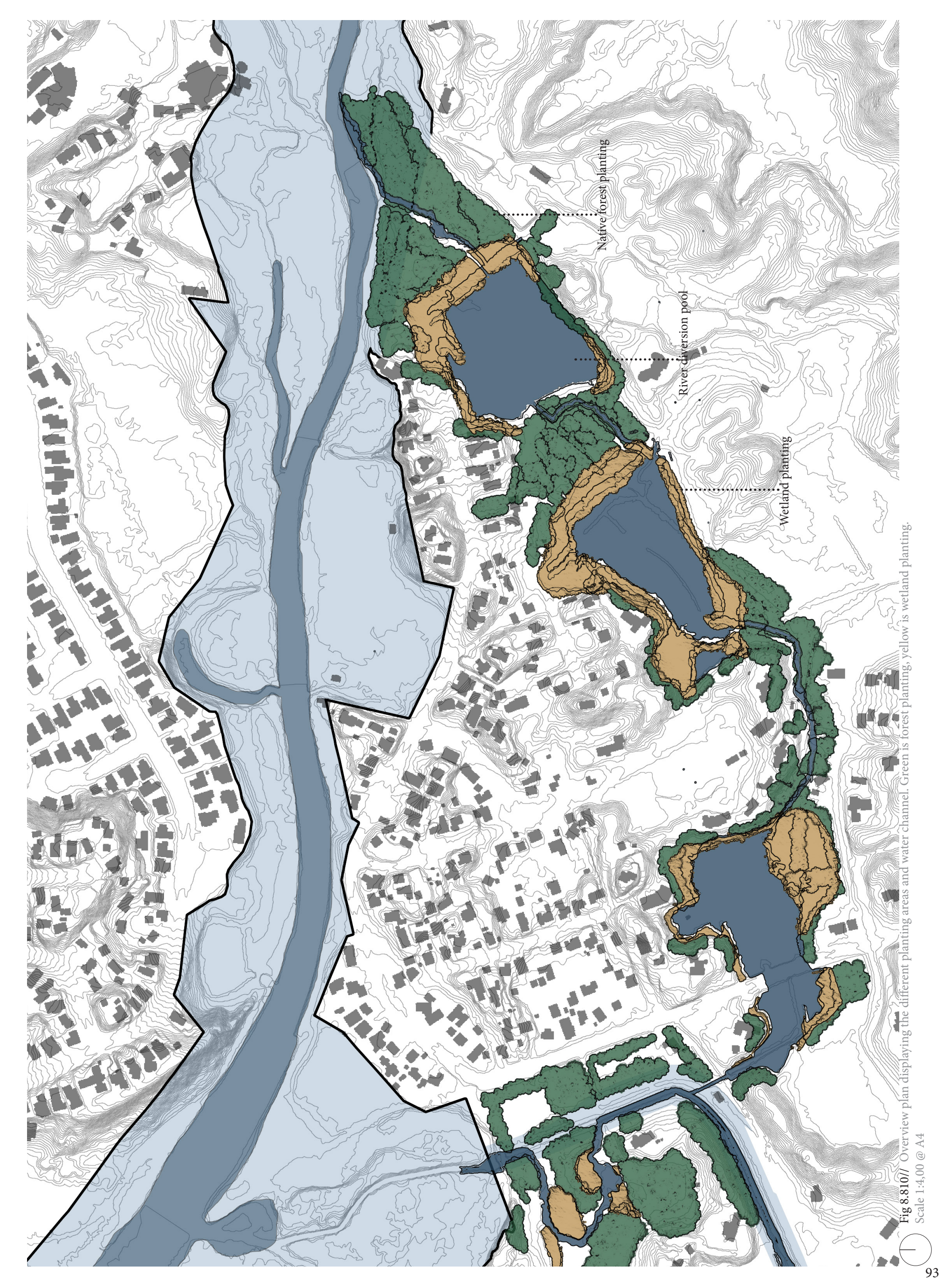




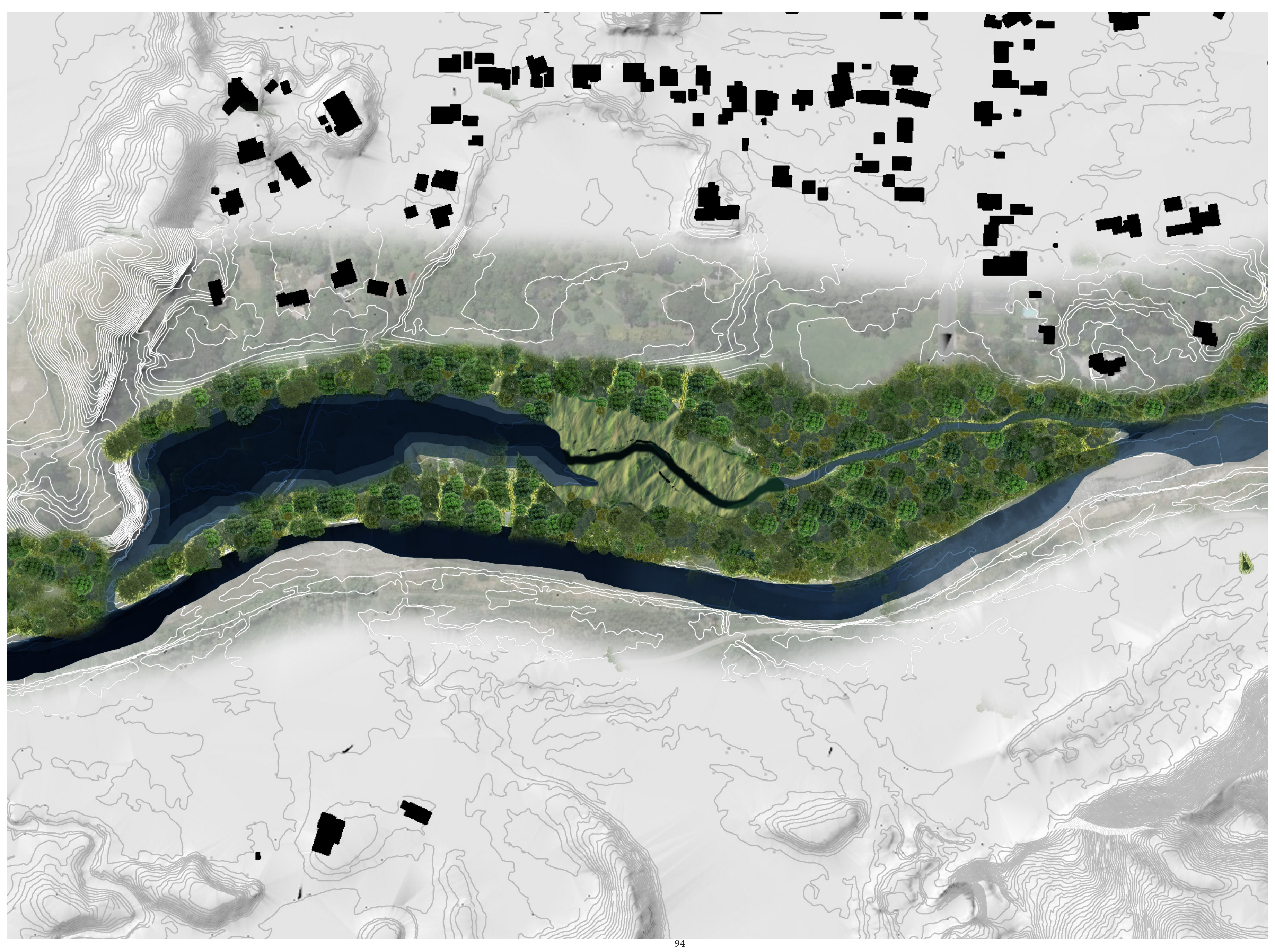




\section{Kuri Road Park}

Further up stream from Otaihanga is an area beside the river with patches of native vegetation across the site. This area naturally floods as can be seen in Fig 3.4, post the latest flooding event of 2017, and as seen water rises almost half way up the stopbank. This is a combination of the river overflowing into the site and a storm water drain at one end of the site spilling into it as well. At the western end of the site, a wetland system already exists, feed by another storm water drain through the stop bank from three ponds in a private garden.

Much like the Otaihanga site, the Kuri Road Park also naturally floods. In this case, it is currently a functioning wetland system at one end rather than an overflow path. The design here expands and enhances the already existing stream and wetland system across the site, retaining the culvert at the western end of the site and adding another inlet at the eastern end. The site is already very low, hence it is naturally flooding, but it will be lowered more to improve its water storage capabilities and to strengthen its already existing structural flood protection.

Re naturalising all the sites along the river is not just an aim to re-establish what may have once been the rivers riparian zone, but to act as a giant sponge. The vegetation along the river catches a lot of the water that falls as rain and absorbs water out of the soil allowing surface water to penetrate the ground.
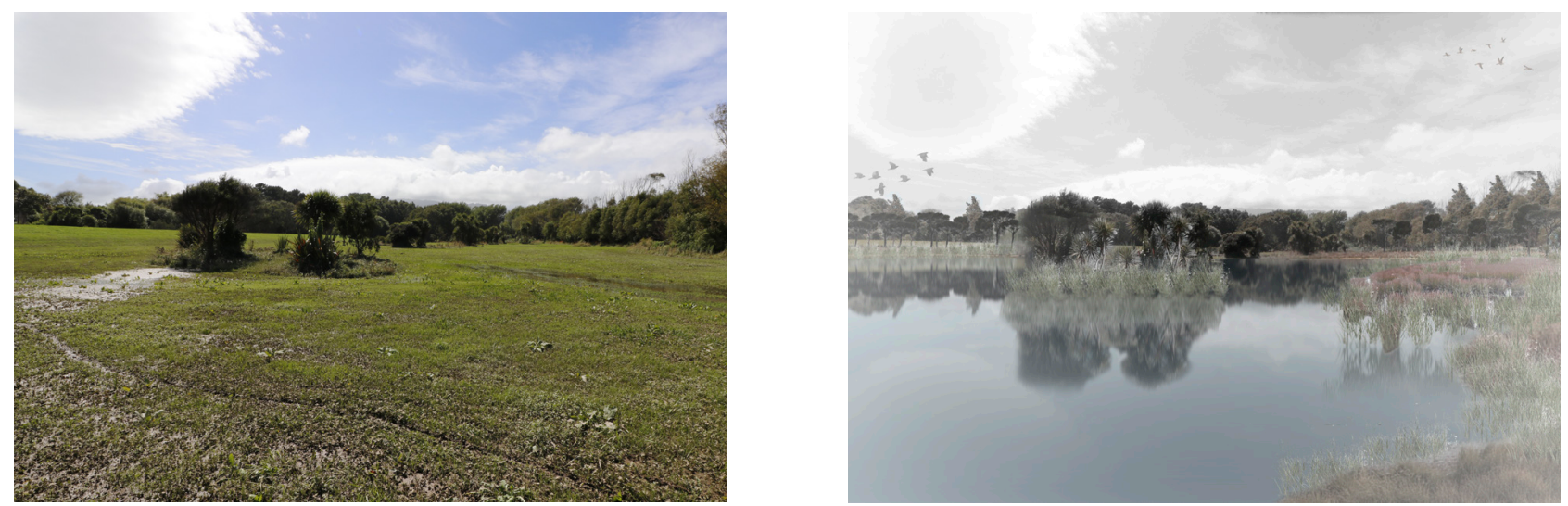

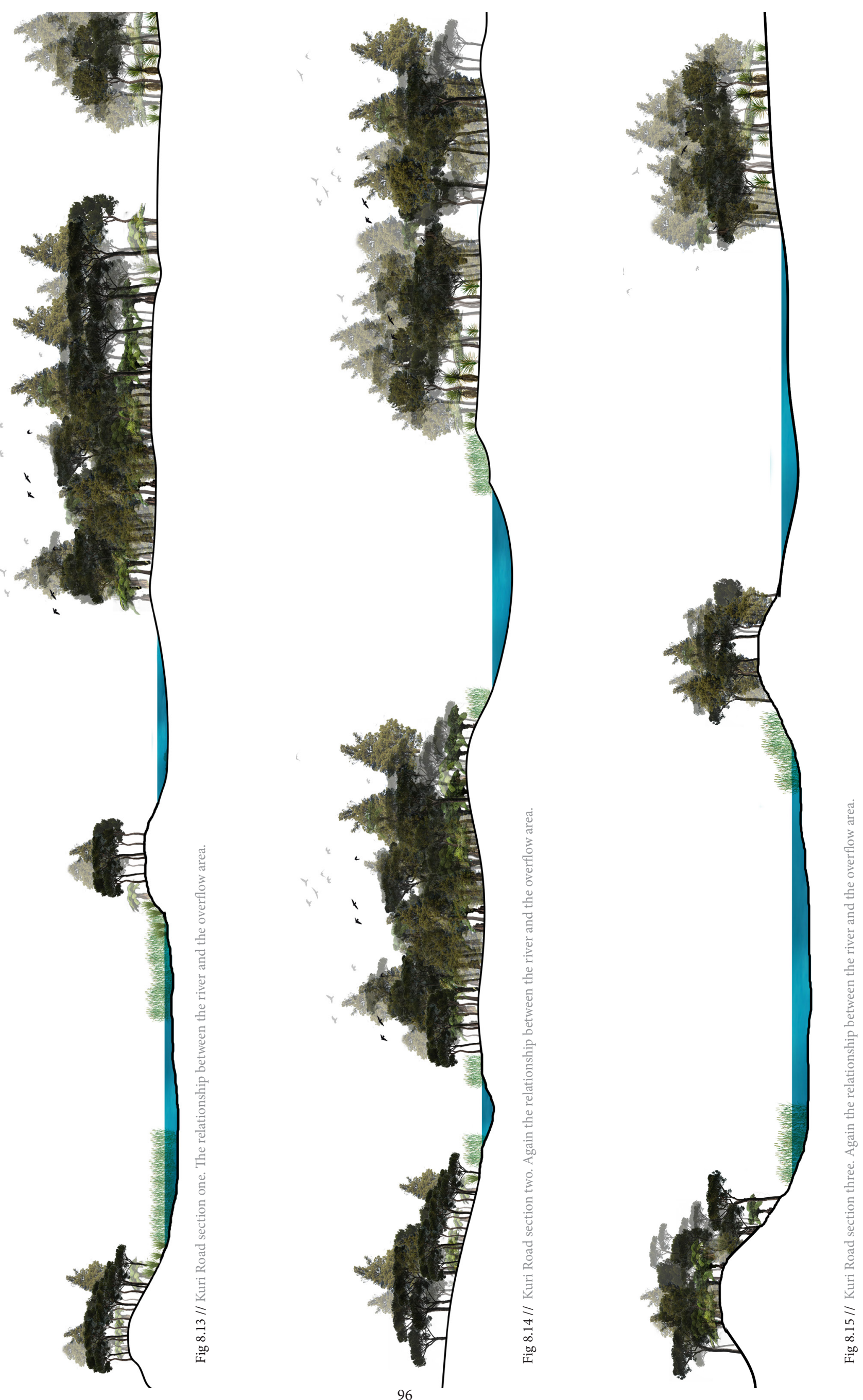


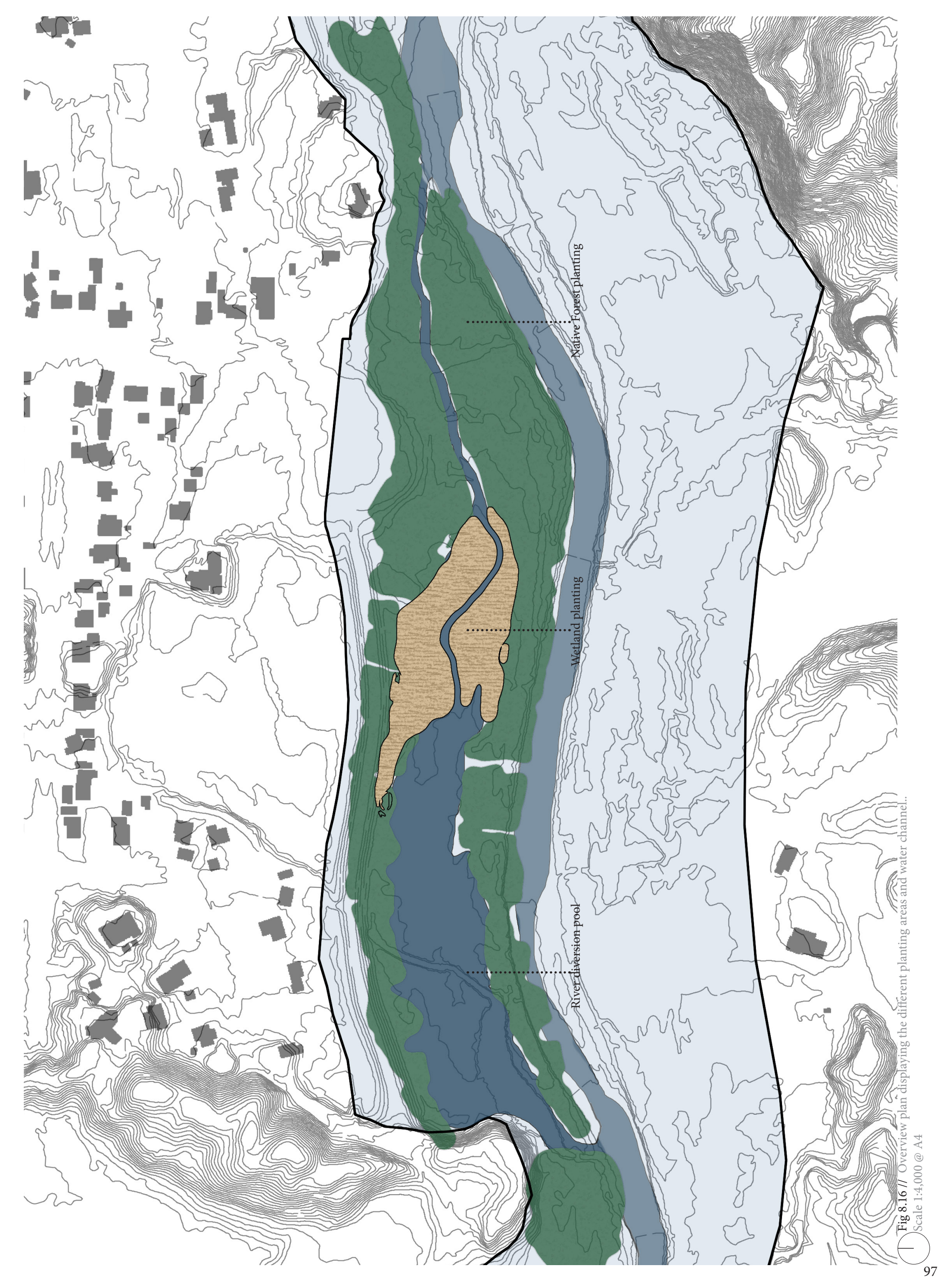




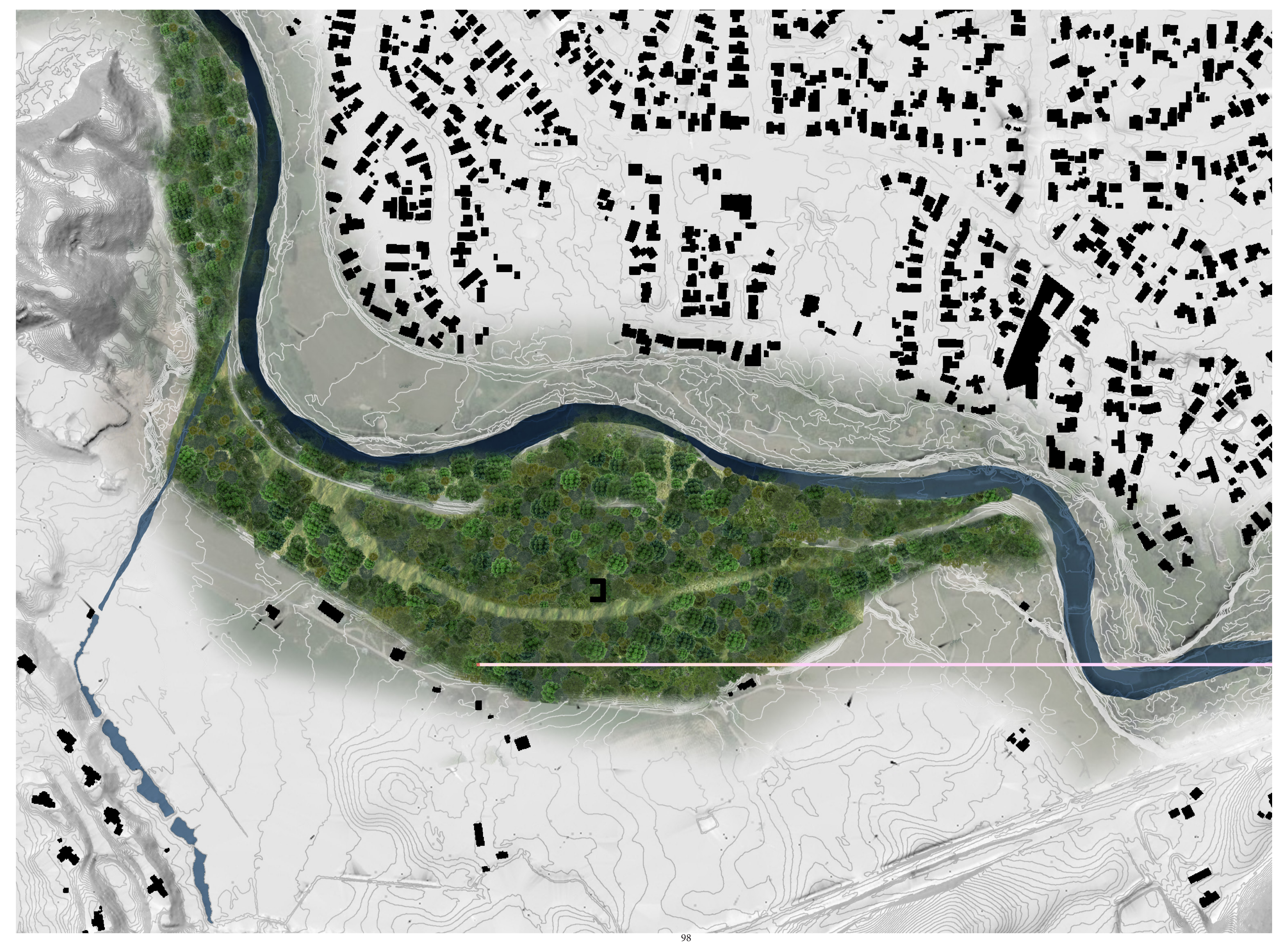




\section{Otaraua Park Overflow Forest}

The third site is currently the location of the Otaraua Park which is dedicated to the people of the Kapiti community. It is an area of recreational fields, riparian planting, walking tracks and farmland. Between the recreational fields and the river, there is a series of riparian planting put in place by the Kapiti District Council. This, with the same along a stream that runs across one end of the site will be retained and enhanced upon. It is a large area of lowland right next to the river with a small stop bank between it and the river, holding back flood waters. But because of this stream that runs at the western end of the site when the river floods, it overflows into the site flooding the sports fields.

The design for this site is to open it up much like the other two. Re-establishing the riparian planting at the eastern end of the site and opening up the stop bank to allow this section to flood.

The existing sports fields will remain in place but heavier planting along the stream will be required. This is so that the attraction of the sports fields is not lost, and it can make an excellent storage area during a flood.

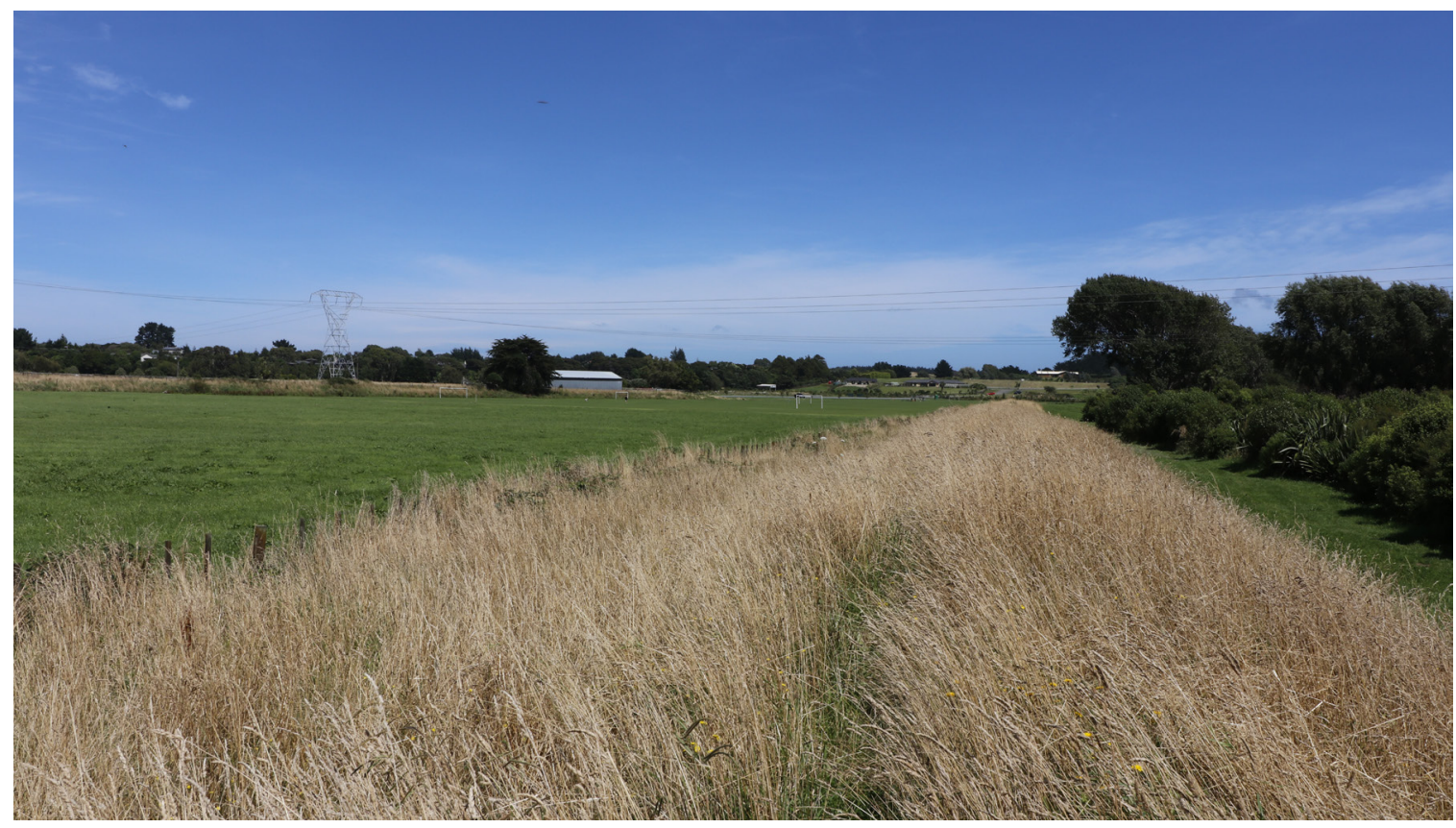

Fig 8.17 // Opposite page // Site three, Otaraua Park design. Different from the others this site doesn’t have a river flow diversion as it is not as low as the other two but floods mostly due to the stream at the western end of the site.

Fig 8.18 // Above Image // Image of the Otaraua site from the stop bank that boarders the river. Render was not done as views would be obstructed via vegetation and no detail would be seen. 

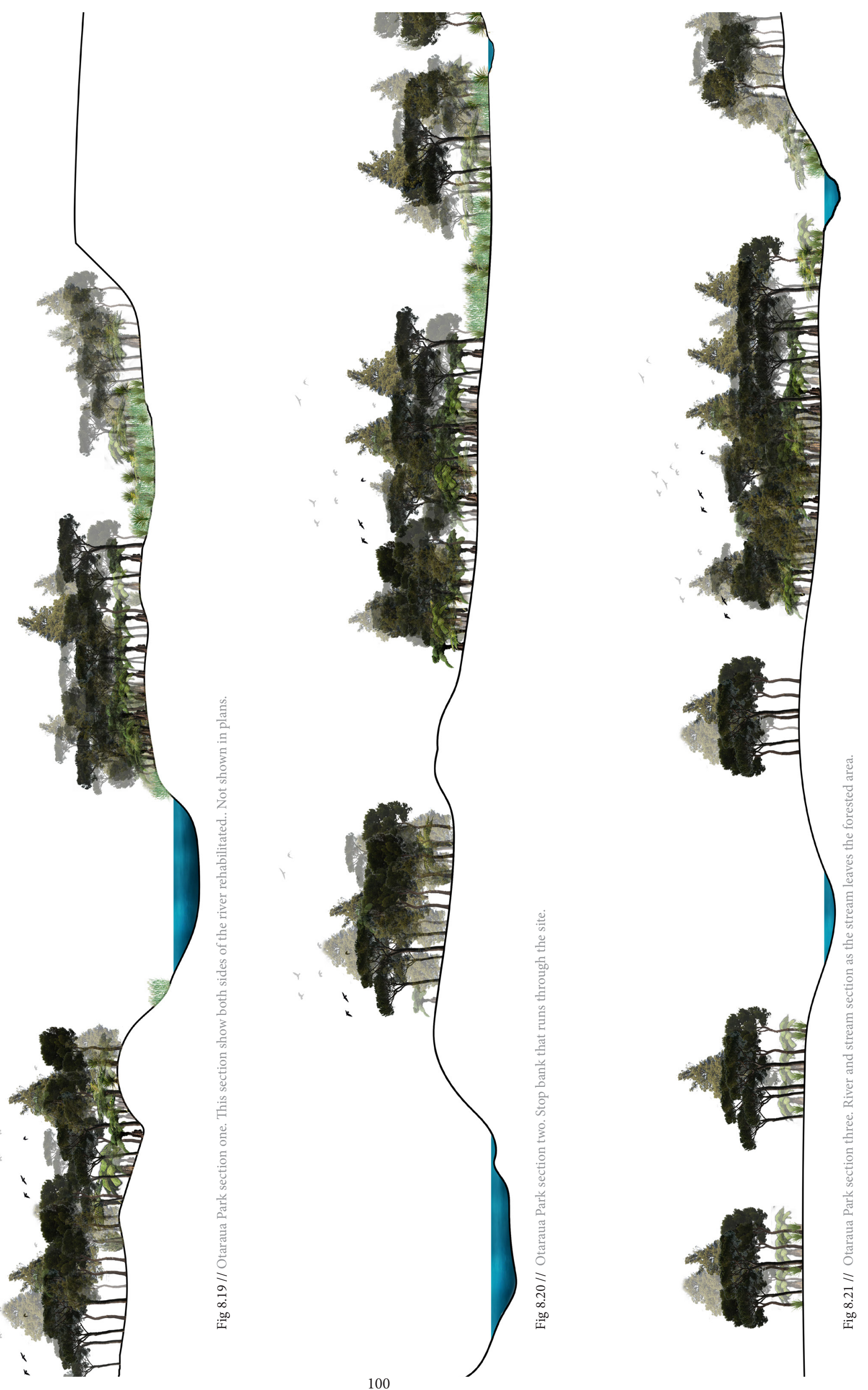
20 5

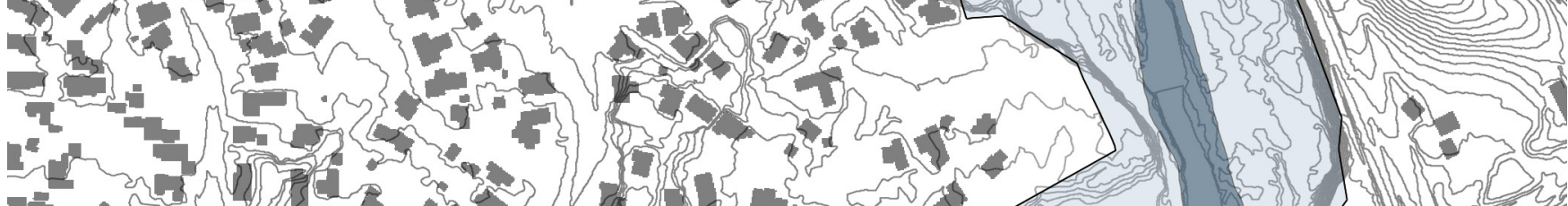


P.

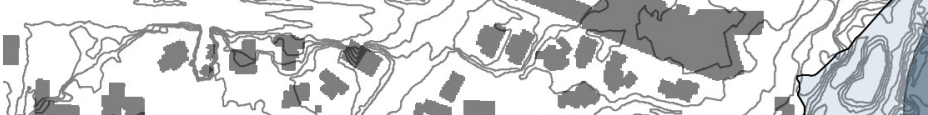
H. $-10+4+T^{2}$ 7 in S. W s

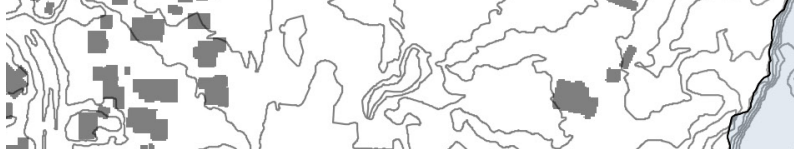
6

TH4 1 42 e the

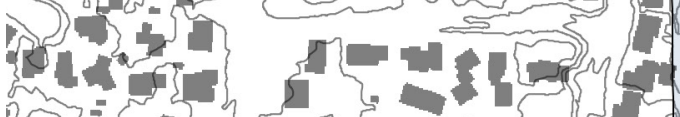
2. - . Lit 0 (1) $4-5$ $3+1+1,-13$
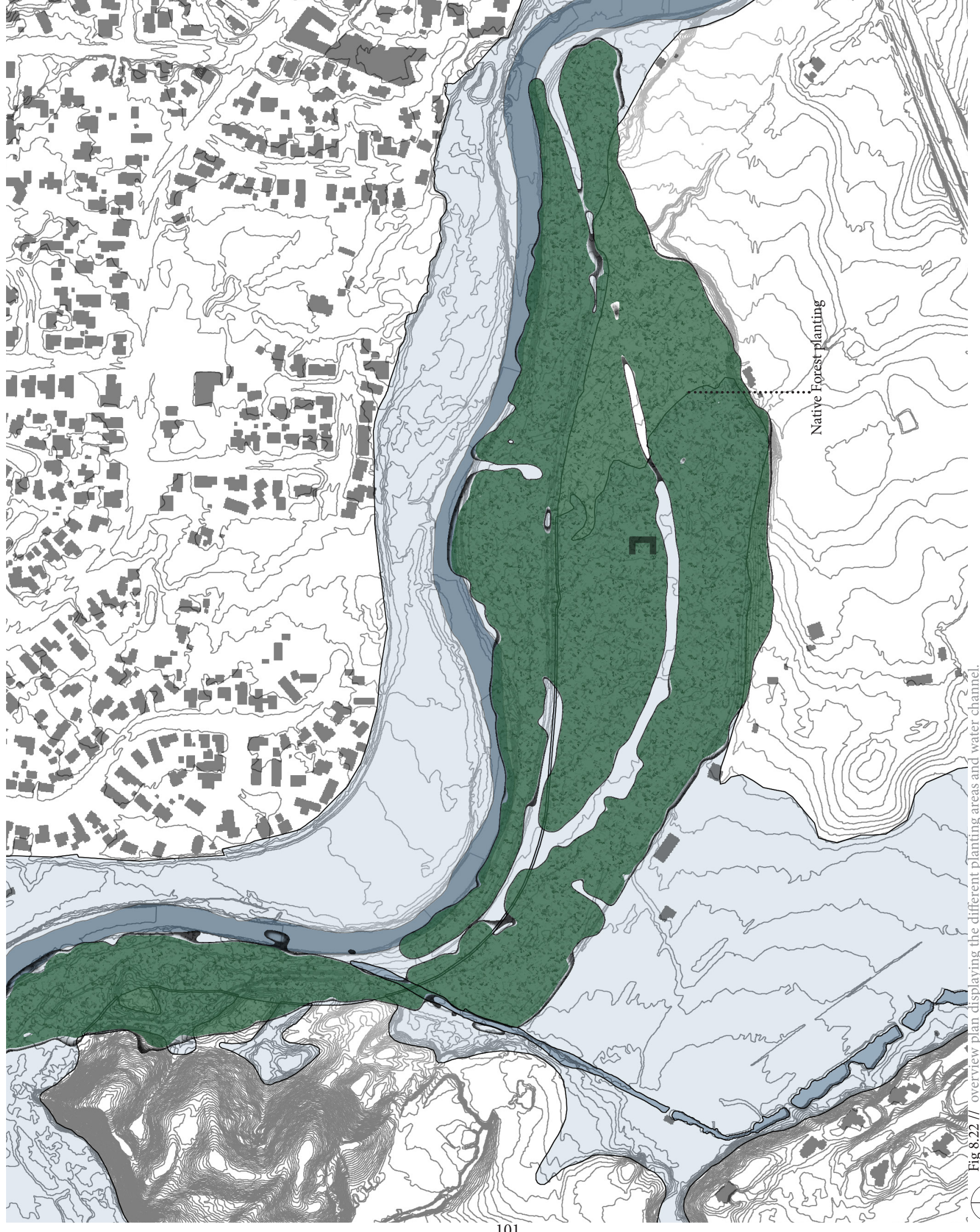


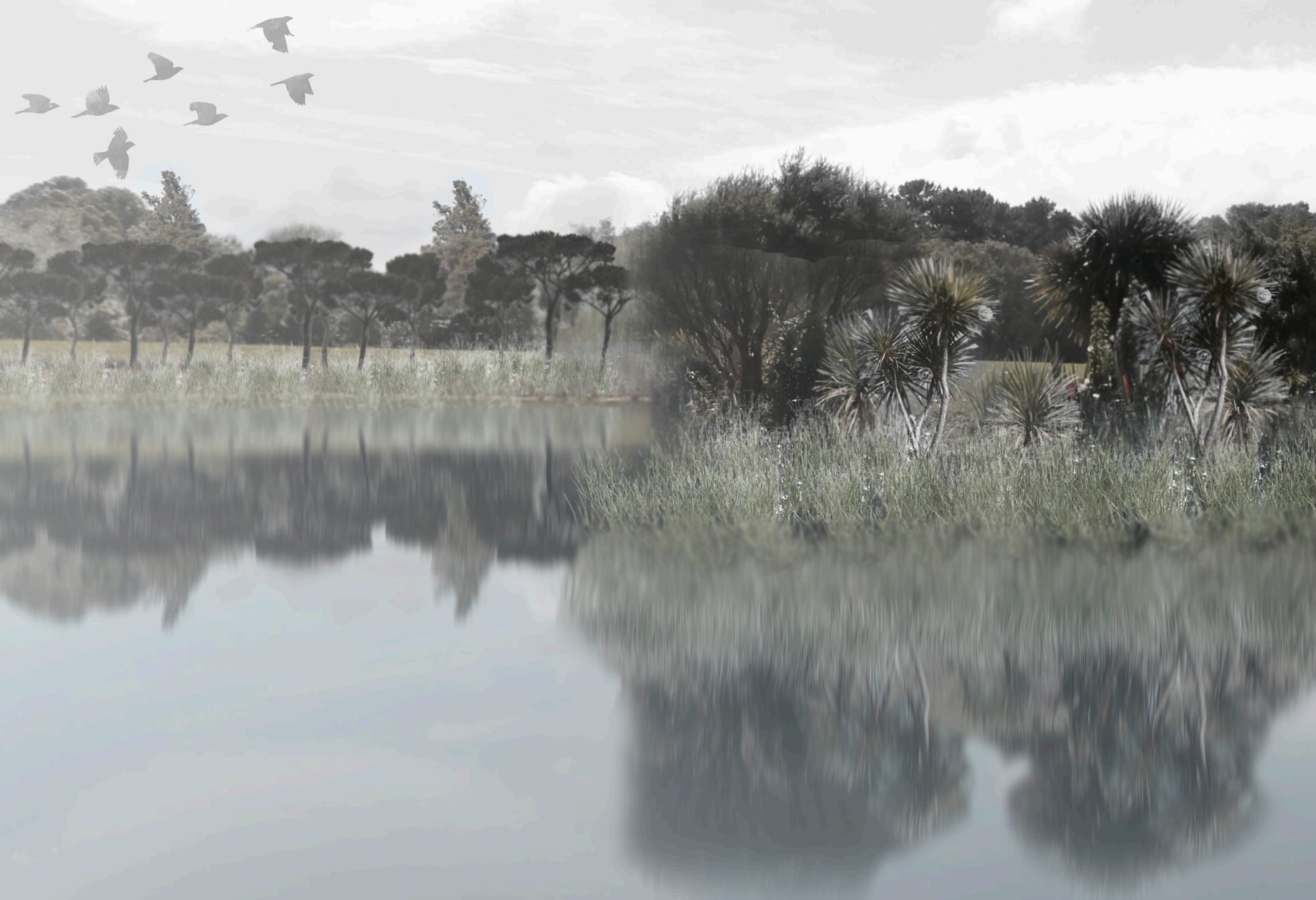




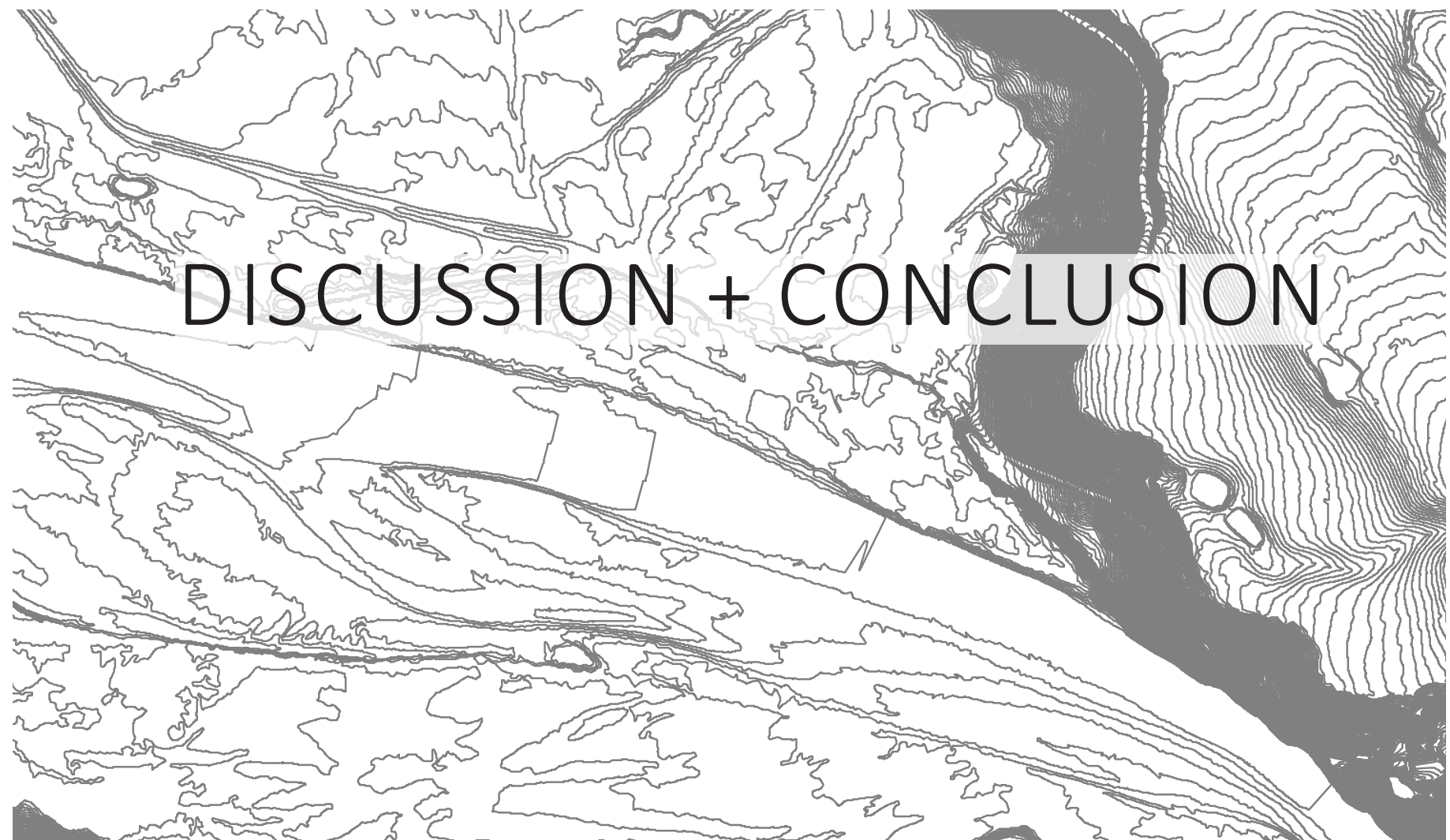

7is/(2)

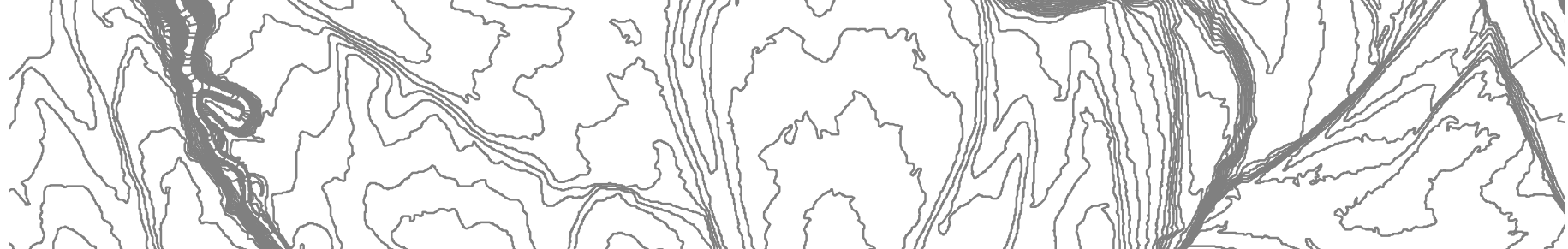
(1) any 5) 1 (n)

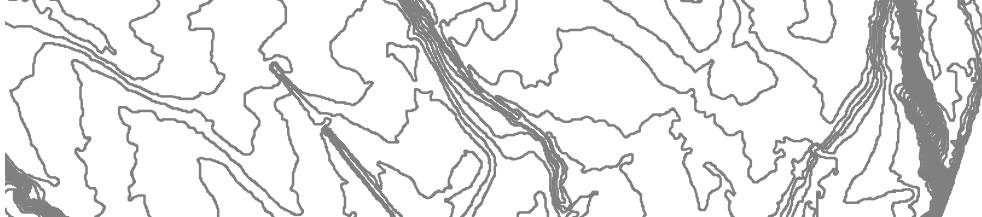

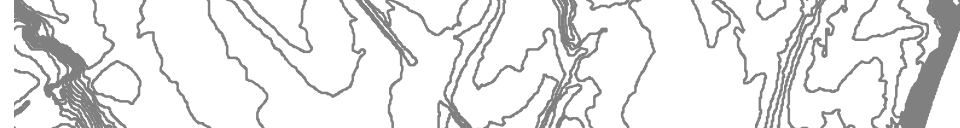
In +

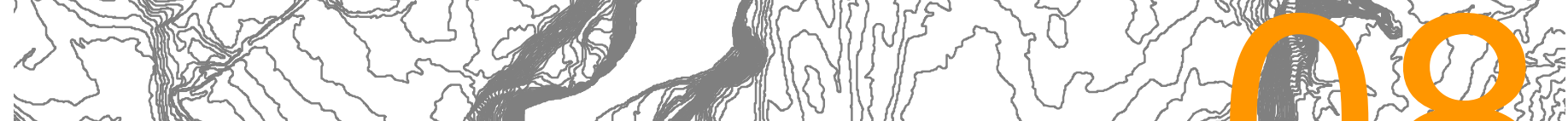
U. (1) 


\section{DISCUSSION}

\section{The Expressway}

The addition of the expressway to the landscape of Kapiti as stated earlier in the research, will open up a corridor creating greater and safer access to and from Wellington and to the north. It will mean less congestion on the current roads around Waikanae, Paraparaumu and the rest of the region. It will create more jobs within the Kapiti Coast and for those that commute each day, will have greater access to areas beyond the Kapiti region. This is good for Kapiti, with greater access, more people will travel to the region.

The hope for the expressway is that because it will become much easier to travel to and from Wellington and north, the population of the region may grow due to such an easy commute. The process of regional growth can sometimes lead to issues arising in order, to maximise housing development. River and stream corridors can be pushed back to make space. In the process of this, it limits the options that can be used to restore these corridors and the only option is to concrete them. However, this can be remedied with some forward thinking, and not needing to cram as many homes into space. But often the case is that residential development happens its own way, without the care for nature.

The route selected for the expressway was chosen to avoid the most sensitive and highly valued ecological areas along the route. Then there are some unavoidable effects of a project like this on the ecology of Kapiti. Bridging, culverting of streams and habitat loss are among some of the negative effects of the project. As part of the environmental basement of the route, these impacts will be addressed by ecological offsetting in accordance with the Greater Wellington Regional Council policy. This will involve enhancements to replace any lost habitat, stream replanting with native vegetation and wetland restoration due to 1.8 hectares being affected by its construction. (Assessment of Environmental Eff Ects: Non-Technical Summary). This brings forward a question asked later in the discussion, "why limit the ecological enhancement and replacement only to affected areas"?

\section{What could be done?}

For the construction of the Mackays to Peka Peka Expressway, retention and replacement of the current ecology was worked into the project's framework, to protect and enhance the ecology around the expressway. So why is it limited to just around the fringes of the expressway, in the creation of a human expressway? Why can't there be the formation of a natural highway parallel or in the case of the Kapiti Coast perpendicular to the piece of infrastructure? As stated previously in the discussion, ecological enhancement and replacement of affected areas were written in as part of the environmental assessment, but this only affects a small fringe of the native ecology that borders the expressway. 
The vast majority of major north-south roading infrastructure travels parallel to the coastlines, and at some point must cross a river or stream along the way. At these intersection points is where the most care is taken in terms of ecological protection and enhancement, so as care is taken not to obstruct the river flow and cause flooding. A second project could be run in collaboration with the expressway project to help improve and protect the quality of the ecological highways that run perpendicular to it.

\section{Settlement}

One of the issues diagnosed at the beginning of the research was settlement and its proximity to flood affected areas, in some cases being directly in the path of flooding. This issue also included the addition of the expressway to the Kapiti landscape and its potential to increase the growth of the region. Growth can mean more people and more people can mean more need for residential development. But with flooding becoming increasingly worse and affecting more areas it doesn't leave many safe places for the region to grow.

The research question being asked of this design led research was, "how can the rehabilitation of our river ecology develop protection strategies to support settlement development on floodplains"? This is why settlement is noticeably missing from the development of the final design. The focus of the research was really the rehabilitation of the river to aid flood protection. This is what the research question evolved into, through the process of the research.

The research became more than just finding ways to live in floodplains, but more about how the issue can be solved along the source. There are many ways that settlement development can be made more resilient to flooding, and that is the approach seen to be taken at this point in time. Different construction methods and hard infrastructure methods are used to protect settlement currently. However, a more resilient river ecosystem means a more resilient community, rivers have been the life of settlement for a long time. This is where the design aims to fix, repairing the river and strengthening it to provide for the surrounding settlement rather than being a hindrance. 


\section{Natural Flood Protection}

Natural flood protection has many benefits that add to the quality of the surrounding landscape. Along with its flood protection qualities, natural flood protection has additional recreational and economic values that add to the surrounding landscape. Natural features of the landscape have their own way of dealing with flood waters as they move down the river. Heavily planted locations absorb more water out of the ground allowing more water to penetrate into the soil during a flood, whereas a concrete channel does not.

Large areas of planting along the river edge absorb the impact of river flow giving more time to prepare further downstream and reducing the damage that fast flows create. This is really all the three final design locations are, some of the largest, most affected areas of the river corridor. Extensively planted in native vegetation, the three large areas along the river are there to slow the waters flow and absorb the impact of its power. This could have been done in many other locations at a smaller scale, a greater effect would be felt this way.

Natural flood protection not only protects our communities from harm, but it protects and nurtures our native ecology, which enhances the landscape and adds recreational value to the region. Some of New Zealand's best locations are in areas of native ecology and hundreds if not thousands of people flock to them every year. The Waikanae River currently has an extensive walking and cycle track network along the river corridor regularly used by the residents of Kapiti. These will be maintained and enhanced as part of the design to continue to attract people to the site.

The Waikanae River is meant to be the link in the chain between the Tararua Ranges and Kapiti Island, two celebrated features of the coastal landscape. But the Waikanae River wasn't portrayed the same. Currently the river seems less important than the rest of the corridor. Rehabilitating it, aims to step it up to the same value as Kapiti Island and the Tararua Ranges. This is where the design comes in. The initial site for rehabilitation will be the stepping stones to creating this and a more resilient river. The initial large pockets of rehabilitation will take time to grow but will eventually work to aid the river system. Situated in some of the worse off areas of the river, these designs will help divert flow and slow its impact.

The Otaihanga site is located in an overflow path and has been designed to utilise that to its advantage. Natural flood protection is more about moving the water away from the river rather than along it. The larger of the other two sites, Otarua Park will only really function as an overflow path in the case of big events. The intention of this site was for the stream that runs along one edge of its area, holding overflow water reducing the addition of extra water to an already swollen river. 
A series of natural flood protection interventions can be economically beneficial to an area. Natural protection is more appealing to visitors and potential home buyers in an area compared to a concrete channel or large view blocking stopbank. But people aren't going to buy or come if they know that the area is susceptible to flooding. The clearer waters and healthier river edges will improve property prices and attract more tourism.

Natural flood protection cannot be done as a half dose; it is needed on a much larger scale than current hard infrastructure methods. As shown through the research a single area of natural protection will have little effect on the big picture. Locally it may make a small change but this is not helpful when the problem is still occurring downstream. This can mean it takes a lot longer to establish this form of protection along a river before it functions efficiently. 


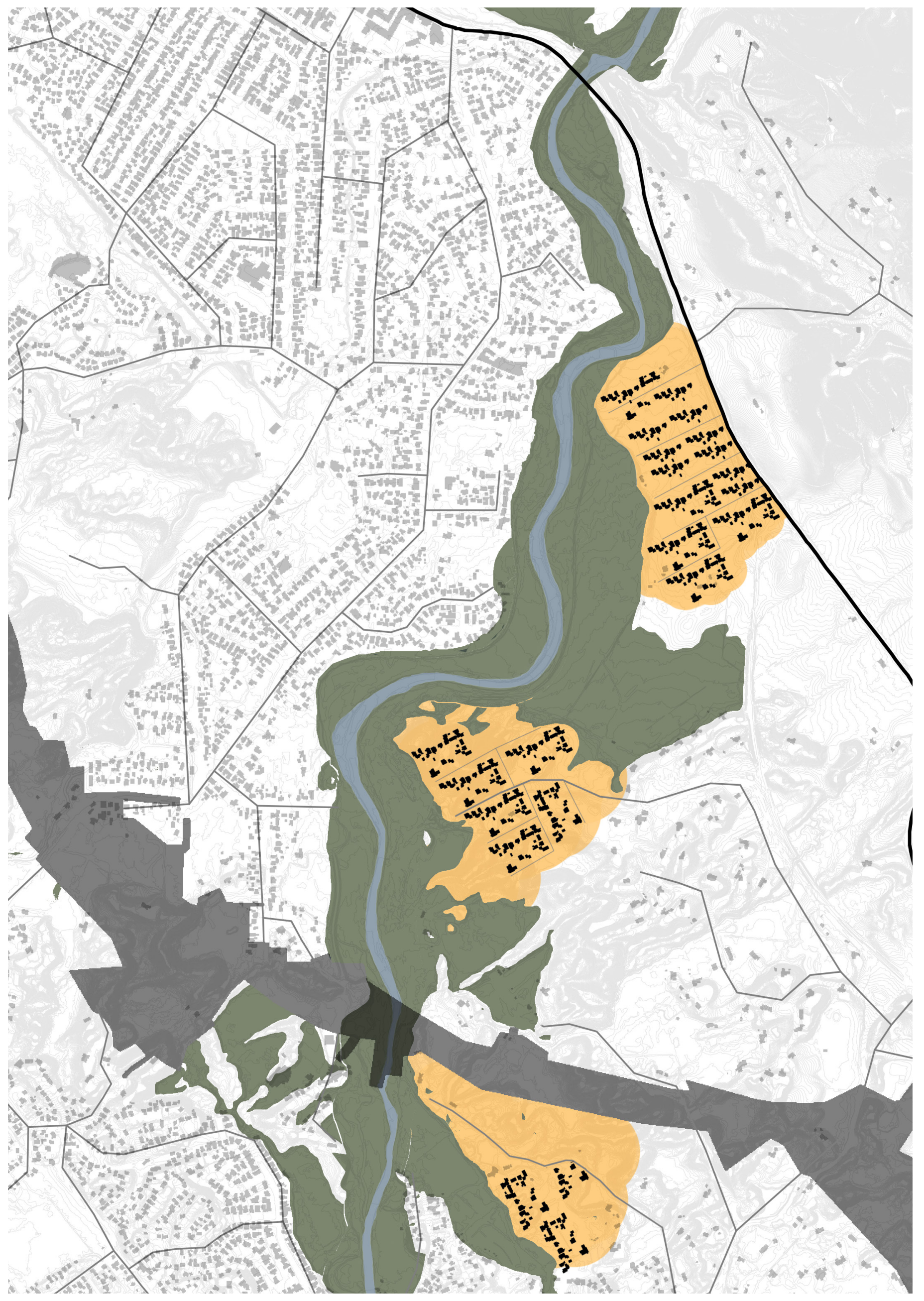

Fig 9.1 // Where further research could go. small pockets of residential development can start to happen within the indents of the ecology. 


\section{CONCLUSION}

The next stage proceeding the rehabilitation of the river corridor could be the beginning of residential development. The intent of the research was to develop strategies to aid settlement of floodplains without the constant fear of floods causing damage. The main focus was developing a plan for the river corridor that would protect current settlement along the Waikanae River and any further development in the future. The rehabilitation of the river ecology was the direction taken. Using a natural flood protection method, in conjunction with small hard infrastructure interventions to aid the function of overflow areas within the rehabilitated areas. But "what happens now"?

The intention of this design was that post completion, settlement could be developed further along the river. It was the intention that the new expressway would create jobs and a want for people to now live in Kapiti. Settlement along the Kapiti Coast began as small pockets of development and eventually expanded, merging and creating what we have today. The next stage of development for this research could be how these settlements develop after the rehabilitation of the river.

Perhaps with the new north-south expressway route additional east-west ecological corridors can begin to form which lead to new settlements located in the gap along the edge of the river.

The intent of the research was to develop strategies to aid settlement of floodplains without the constant fear of floods causing damage, based along the Waikanae River, in an area that has the potential to grow rapidly with the Kapiti Expressway being developed. Although the aid of settlement in this situation is the main goal, the pressing issue that hinders this is the current flooding of the Waikanae River.

Flood protection in the past has not always been the most successful venture, with humans attempting to command and bend rivers to their own desires, with the intention to solve a naturally occurring process. Flooding is a natural occurrence for any river system, but it is unproductive for human life as it causes damage and disturbance. This design aims to achieve a complete river solution that allows the river to express itself and allows the potential for river edge development to happen without worry of damage.

The design will allow this to happen and further research could explore the development of settlement along the edge of the ecological flood protection scheme and possibly see how this may work for other cases with similar circumstances. 


\title{
LIST OF FIGURES
}

\section{All images throughout this document are products of the author, unless otherwise specified.}

\author{
Chapter 1- The Site
}

Fig 2.4 // Top image // A view of Kapiti Coast from the hills above Paekakariki Source: https://nzbybike.com/regions/wellington/regional-ride/kapiti-coast/

Fig 2.5 // Bottom image // Photo taken in the 1960s of the Waikanae River after some flood protection had been implemented.

Source: https://waikanaewatch.org/2016/01/28/waikanae-river-mouth-and-estuary-late-1960s/

Fig 2.7 // Top image // Waikanae River mouth looking through to Otaihanga and Waikanae Source: http://www.stuff.co.nz/dominion-post/news/kapiti/9912744/Kapiti-towns-switch-to-borewater

Fig 2.8 // Bottom image // Otaki River mouth. The landscape is vastly different to the Waikanae River mouth.

Source: https://www.youtube.com/watch?v=zxWkn8SwYF8

Fig 2.10 // Top image // Waikanae Township 1947 with the Waikanae

River highlighted in red looking east.

Fig 2.11 // Middle image // Waikanae Township 1969 with the Waikanae River highlighted in red looking west.

https://waikanaewatch.org//?s=Waikanae+from+the+air\&search=Go

Fig 2.12 // Bottom image // Waikanae Township 2016 with the Waikanae river highlighted in red looking east.

http://www.davidwallphoto.com/detail/57335-Waikanae-River-and-Lagoon,-Kapiti-Coast,-

Wellington-region,-North-Island,-New-Zealand-_-aerial.html

Fig 2.14 // Top image // Painting of the Waikanae River somewhere near Otaihanga.

http://www.gw.govt.nz/assets/Our-Services/Flood-Protection/Waikanae-River/FP---Waikanae-FMP. pdf 


\section{Chapter 2-The Issues}

Fig 3.2 // Top image // Waikanae River in flood December 1985

Source: http://www.gw.govt.nz/assets/Our-Services/Flood-Protection/Waikanae-River/FP--Waikanae-FMP.pdf

Fig 3.3 // Bottom image // Waikanae River in flood 2016, closed the Otaihanga Domain Source: http://www.stuff.co.nz/national/84369651/Heavy-rain-floods-homes-closes-roads-as-badweather-hits-Wellington

Fig 3.6 // Top image // Otaki River in flood 1931

Source; http://horowhenua.kete.net.nz/en/site/images/9321-otaki-river-in-flood

Fig 3.7 // Bottom image // Otaki River flood, December 1982 passing under the main trunk line rail bridge.

Source: http://www.gw.govt.nz/assets/Our-Services/Flood-Protection/Otaki-River/FP---Otaki-FMP. pdf

Fig 3.16 // Top Left // Riparian planting, Urban and Landscape Design Framework for Mackays to Peka Peka Expressway

Fig 3.17 // Bottom Left // Specimen Trees under planted with Ground cover, Urban and Landscape Design Framework for Mackays to Peka Peka Expressway

Fig 3.18 // Top Right // Wetland/Storm water Pond Planting, Urban and Landscape Design Framework for Mackays to Peka Peka Expressway

Fig 3.19 // Bottom Right // Storm water swales, Urban and Landscape Design Framework for Mackays to Peka Peka Expressway

Source: http://www.nzta.govt.nz/assets/projects/mackays-to-peka-peka-application/docs/ management-plan-approved-landscape-part-3.pdf 


\section{Chapter 4- Post Initial Design}

Fig 5.2 // Waikanae River Ecological Corridor, Waikanae River Environmental Strategy. Source: http://www.gw.govt.nz/assets/floodprotection/WaikanaeRiverEnvironmentalStrategylowres.PDF

Fig 5.4 // Next Page // Potential Bird, Lizard, Fish and Plant species to be seen along the Waikanae River.

Source: http://www.kapitiislandnaturetours.co.nz/kapiti-island/2015-10-19-082655

http://www.doc.govt.nz/Documents/parks-and-recreation/places-to-visit/wellington/waikanaeestuary-fact-sheet.pdf

Wetland Restoration. A Handbook For New Zealand Freshwater Systems | Books \& Monographs $<$ http://www.landcareresearch.co.nz/publications/books/wetlands-handbook>. www.reptiles.org.nz/sites/default/files/legacy/kapiti-coast-lizard-gardens.pdf>.

Fig 5.6 // modified rivers accelerate flow and cause more damage downstream.

Fig 5.7 // a river naturally meanders which improves water quality and reduces flood risk. Flows are slowed and the peak of floods are delayed giving more time to prepare.

Fig 5.8 // Narrow river run too quickly and increases flood risk downstream

Fig 5.9 // reconnecting the river with floodplains to protect vulnerable communities.

Source : Youtube, 2016, https://www.youtube.com/watch?v=21YAP8RF_sw.

\section{Chapter 5- Precedents + Literature}

Fig 6.1 // Engineering and ecosystem based approaches to river management.

Source: Brierley, Gary J and Kirstie A Fryirs. River Futures. 1st ed. Washington, DC: Island Press, 2008. Print.

Fig 6.2 // SLA three step approach.

Source: http://alvstaden.goteborg.se/wp-content/uploads/2012/12/rivercity_vision_eng_web.pdf

Fig 6.4 // Michel Desvigne, Biesbosch Stad Rotterdam, High ground low ground diagram Fig 6.6 // Michel Desvigne, Biesbosch Stad Rotterdam, Model Photograph Source: Tiberghien, Gilles A, Michel Desvigne, and James Corner. Intermediate Natures. 1st ed. Basel: Birkhäuser, 2009. Print. 


\section{BIBLIOGRAPHY}

Teara.Govt.Nz, http://www.teara.govt.nz/en/wellington-places/page-15.

The New Zealand Herald, http://www.nzherald.co.nz/floods/news/article.cfm?c_ id=205\&objectid=9005702.

New Zealand Transport Agency, 2013, http://www.nzta.govt.nz/assets/projects/mackays-to-pekapeka-application/docs/management-plan-approved-ecological-part-2.pdf.

Agency, NZ. "Mackays To Peka Peka | NZ Transport Agency”. NZTA.Govt.Nz, 2017, https://www. nzta.govt.nz/projects/wellington-northern-corridor/mackays-to-peka-peka/.

New Zealand Transport Agency, http://www.nzta.govt.nz/assets/projects/mackays-to-peka-pekaapplication/docs/non-technical-summary.pdf.

Nature.Org, 2017, http://www.nature.org/ourinitiatives/habitats/riverslakes/benefits-of-healthyfloodplains.xml.

Brierley, Gary J and Kirstie A Fryirs. River Futures. 1st ed., Washington, DC, Island Press, 2008,

Brookes, A. “Traditional Engineering Methods, Physical Consequences And Alternative Practices”. Progress In Physical Geography, vol 9, no. 1, 1985, pp. 44-73. SAGE Publications, doi:10.1177/030913338500900103.

New Zealand Transport Agency, 2017, http://www.nzta.govt.nz/assets/projects/mackays-to-pekapeka-application/docs/management-plan-approved-ecological-part-1.pdf.

New Zealand Transport Agency, 2013, http://www.nzta.govt.nz/assets/projects/mackays-to-pekapeka-application/docs/management-plan-approved-ecological-part-4.pdf.

Greater Wellington Regional Council, http://www.gw.govt.nz/assets/Emergencies--Hazards/ Flooding_Hazard_Kapiti.pdf.

Kapiti Coast District Council, http://www.kapiticoast.govt.nz/contentassets/ e85039e0057c4c3da845fcb8468e6b75/guide-to-growing-native-plants-in-kapiti.pdf.

Kapitinow.Co.Nz, http://www.kapitinow.co.nz/history.

BBC News, 2015, http://www.bbc.com/news/uk-25929644. 
Openspace.Org.Nz, http://www.openspace.org.nz/site/covenant_stories/stories/kapiti_coast_te_ hapua_wetland.aspx.

New Zealand Transport Agency, 2017, http://www.nzta.govt.nz/assets/projects/mackays-to-pekapeka-application/docs/management-plan-approved-landscape-part-1.pdf.

New Zealand Transport Agency, 2015, https://www.nzta.govt.nz/assets/projects/mackays-to-pekapeka/docs/M2PP-Expressway-Tour-Guide-April-2015.pdf.

Environmental Protection Authority, 2017, http://www.epa.govt.nz/Publications/M2PP-NonTechnical-Summary.pdf.

New Zealand Transport Agency, http://www.nzta.govt.nz/assets/projects/mackays-to-peka-pekaapplication/docs/management-plan-approved-landscape-part-3.pdf.

MAXWELL, JOEL. "Heavy Rain Floods Homes, Closes Roads As Bad Weather Hits Wellington". Stuff, 2017, http://www.stuff.co.nz/national/84369651/fire-services-called-to-pump-out-floodedhomes-road-closed-as-bad-weather-hits.

Valleywater.Org, http://www.valleywater.org/services/NaturalFloodProtection.aspx.

Nature.Org, 2017, http://www.nature.org/ourinitiatives/habitats/riverslakes/natural-solutions-forreducing-flood-risk.xml.

Nature.Org, 2017, http://www.nature.org/ourinitiatives/habitats/riverslakes/natural-solutions-forreducing-flood-risk.xml.

Greater Wellington Regional Council, http://www.gw.govt.nz/assets/Our-Services/Flood-Protection/ Otaki-River/FP---Otaki-FMP.pdf.

Profile.Idnz.Co.Nz, http://profile.idnz.co.nz/kapiti/

population? WebID $=110 \& B M I D=20 \&$ EndYear $=2001$.

River City, 2012, http://alvstaden.goteborg.se/wp-content/uploads/2012/12/rivercity_vision_eng_ web.pdf.

Nzdotstat.Stats.Govt.Nz, http://nzdotstat.stats.govt.nz/wbos/Index. aspx?DataSetCode=TABLECODE7541\# .

Tiberghien, Gilles A et al. Intermediate Natures. 1st ed., Basel, Birkhäuser, 2009,.

Floodready.Vermont.Gov, 2017, http://floodready.vermont.gov/flood_protection. 
Greater Wellington Regional Council, 1997, http://www.gw.govt.nz/assets/Our-Services/FloodProtection/Waikanae-River/FP---Waikanae-FMP.pdf.

Greater Wellington Regional Council, 1997, http://www.gw.govt.nz/assets/Our-Services/FloodProtection/Waikanae-River/FP---Waikanae-FMP.pdf.

Greater Wellington Regional Council, 2010, http://www.gw.govt.nz/assets/Our-Services/ Flood-Protection/Waikanae-River/WGNDOCS-722672-v4-WaikanaeFMP10YearReviewSummaryReportFINALVERSION.pdf.

GW.GOVT.Nz, 2017, http://www.gw.govt.nz/waikanaeriver/.

Greater Wellington Regional Council, http://www.gw.govt.nz/assets/floodprotection/ WaikanaeRiverEnvironmentalStrategylowres.PDF.

Landcareresearch.Co.Nz, 2017, http://www.landcareresearch.co.nz/publications/books/wetlandshandbook.

American Rivers, https://www.americanrivers.org/threats-solutions/restoring-damaged-rivers/ benefits-of-restoring-floodplains/. 


\section{FLOOD OF ECOLOGY}

FLOODPLAIN HABITATION

BY

Christopher Stanislaw Braczek 